\title{
HILGARDIA
}

A Journal of Agricultural Science Published by the California Agricultural Experiment Station

CONTENTS

\section{RELATION BETWEEN AUCTION PRICES AND SUPPLIES OF CALIFORNIA FRESH BARTLETT PEARS}

SIDNEY HOOS and S. W. SHEAR 


\section{CONTENTS}

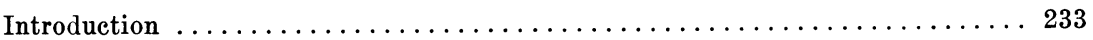

Relations between weekly auction prices and sales................ 235

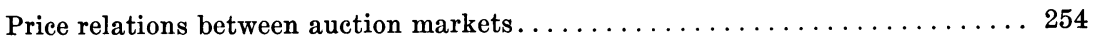

Relations between pears and other fresh fruits................. 265

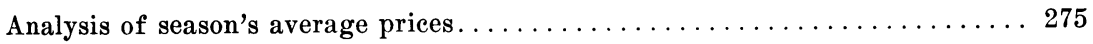

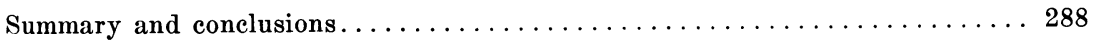

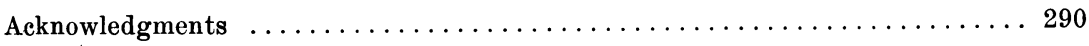

Appendix A: Trends in ratios of prices and unloads............... 291

Appendix B: The relations of pears to plums, peaches, and oranges based on linear arithmetic demand functions...................... 293

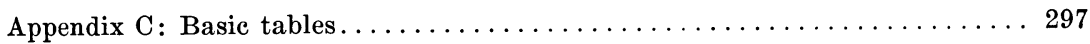





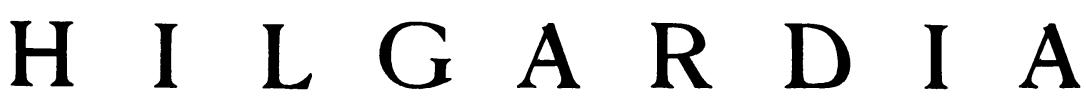

A Journal of Agricultural Science Published by

the California Agricultural Experiment Station

VoL. 14

JANUARY, 1942

No. 5

\section{RELATION BETWEEN AUCTION PRICES AND SUPPLIES OF CALIFORNIA FRESH BARTLETT PEARS ${ }^{1,2}$}

\author{
SIDNEY HOOS ${ }^{3}$ and S. W. SHEAR ${ }^{4}$
}

\section{INTRODUCTION}

A PRIMARY PURPOSE of the present study is to present more factual information than heretofore has been available on certain characteristics of the price behavior of California Bartlett pears. Special attention is given to particular relations within the complex of pear prices, and various influences that enter into the determination of auction market prices are analyzed and discussed. A secondary purpose of the study is to present some analytical background that is necessary in order to view the recent development of the California fresh Barlett pear industry and understand its present status. Therefore this discussion of California Barlett prices, shipments, and relations to other fruits may be considered as a means of emphasizing and elucidating some of the problems that face the industry. To cope with many of these problems there has been enacted in recent years, state and federal legislation which has often resulted in marketing agreements. Here no attempt is made to determine the feasibility or success of the various pear marketing agreements that have been instituted. But in conjunction with additional information, the subsequent analyses and discussions may be helpful in evaluating some of them.

The wide scope of even such a limited subject as pear prices necessitates concentration, in a single study, on only a small segment of the whole. Hence, this investigation is limited to the behavior of auction

\footnotetext{
${ }^{1}$ Received for publication September 27, 1940.

${ }^{2}$ Paper No. 101, The Giannini Foundation of Agricultural Economies.

${ }^{3}$ Instructor in Agricultural Economies, Junior Agricultural Economist in the Experiment Station, and Junior Agricultural Economist on the Giannini Foundation; resigned June $30,1941$.

4Associate Agricultural Economist in the Experiment Station and Associate Agricultural Economist on the Giannini Foundation.
} 
prices of California fresh Bartletts. Consideration is given to the supplies and prices of other pears and of certain other fresh fruits, however, to the extent that such study helps to explain the behavior of prices of California shipping Bartletts. Several aspects of fresh-pear prices discussed in an earlier general study of the pear industry ${ }^{5}$ will be considered here in more detail.

In several respects the prices of California Bartletts are a convenient medium for the study of fresh-fruit prices. The large bulk of fresh shipments is sold through highly organized auction markets in the large centers of population in the Middle West and the East. For a period of about twenty years, there are available daily auction sales and weightedaverage daily auction prices from which may be constructed weightedaverage prices for various time periods such as weeks, months, or seasons. In addition, federal and state marketing agreements have made available, for recent years, much detailed information, such as weightedaverage prices of different sizes of fresh pears. Such diverse and carefully compiled series of prices serve as a reliable price record suitable for analysis and study.

Because of their perishability, California Bartletts cannot be stored over long periods. Since most shipping Bartletts are not stored at all but move into consumption immediately, there is no carryover of the fresh fruit from one season into another. In some respects, absence of carryover simplifies the problems in price analysis since the crop of one season does not directly influence the price of subsequent seasons. The alternative disposition of pears, however, into shipping, canning, and drying outlets complicates the analysis of fresh Bartlett auction prices because the volume of supplies entering into fresh shipments is a function of the prices and supplies of those canned and dried. The distribution of California Bartletts in various uses may be indicated by the following data. Out of the average annual harvested production of approximately 195,000 tons for the five years 1935-1939, about 35 per cent was canned and 18 per cent was dried. ${ }^{\circ}$ Bartletts have not yet been marketed in fresh frozen form, nor does this method of utilization appear likely in the near future. Of the 92,500 tons consumed annually in fresh form during 1935$1939,71,000$ tons were shipped out of the state. California Bartletts compete in consumption with other fresh fruits during the major part of the shipping season, and with the Pacific Northwest Bartletts during the last third of the shipping season. Thus the prices of California Bartletts are related to those of other pears and fruits.

\footnotetext{
${ }^{5}$ Shear, S. W. Economic aspects of the pear industry. California Agr. Exp. Sta. Bul. 452:1-107.1929. (Out of print.)

${ }^{6}$ Shear, S. W. Deciduous fruit statistics as of January, 1940. Univ. of California Giannini Foundation Mimeo. Rept. 69:72. 1940.
} 


\section{RELATIONS BETWEEN WEEKLY AUCTION PRICES AND SALES}

In the investigation of changes in time series of an economic nature, such as statistics on production and movement of supplies and prices, increasing attention is being given to the kinds of changes known as secular trends, cyclical waves, seasonal variations, and residual variations. A particular time series may be broken down into these four components which may be studied separately and in combination with each other. Secular trends and seasonal variations are often measured in order to eliminate their influence upon cyclical movements and thereby bring these movements into bolder relief. The study of secular trend and seasonal variation, however, is important for reasons other than the elucidation of cyclical movements. What have been viewed as residual variations may not be random in a probability sense, but the result of influences that have not been apparent until intensive study has been made of the economic and statistical relations involved. For some commodities, especially perishable ones, seasonal variation in the prices is of importance at least equal to cyclical and secular movements.

Unit-Time Intervals. - In the study of prices of a specific commodity, it is necessary to give some consideration to the appropriate time units to use. In certain analyses it may be essential to consider only annual prices; in others, monthly prices; in many, weekly prices ; and in some, daily prices. The specific object of an investigation largely determines the unit-time intervals for the prices used. In the study of short-time price movements of a perishable commodity with a short marketing life, such as Bartlett pears, it is not only advantageous but also necessary to use prices of time units not longer than a week because available or potential supplies that influence price may change significantly within a period of several days or a week. Since the major part of the marketing season for Bartletts is about three months, monthly prices do not adequately reveal the short-run price movements within a season. The minimum time interval that discloses the important short-run price movements of California Bartletts is a week, and for some purposes the use of daily prices is helpful. In the analysis of seasonal variation in California fresh Bartlett auction sales and prices, weekly data have been used.

The problem of seasonal variation is of special importance in the study of perishable commodities such as fresh fruits and vegetables that are marketed and consumed in a relatively short interval of time. Perishability, that is, change in physical condition over time, largely determines the possibility of storage, and the length of time for which a commodity may be stored under ordinary conditions varies inversely 
with its degree of perishability. The high perishability of some fresh fruits and vegetables necessitates their rapid marketing and immediate consumption. Although the relation between perishability, rate of marketing, and consumption is modified by elements such as cold storage, the degree of the relation and not its nature is affected. California fresh Bartletts are highly perishable, and only a few are held in cold storage, and then only for a few weeks, because the fruit deteriorates rapidly in quality and appearance even in cold storage. In addition, later Bartletts from other states and late varieties of pears compete with California Bartletts that have been stored, which introduces considerable speculative risk.

California Bartletts are grown in several different sections of the state, ${ }^{7}$ and the period during which they mature and are harvested is a relatively short one, usually about three months. ${ }^{8}$ Moreover, about four weeks after the first shipments from a particular district, the volume of movement from that district usually reaches a maximum. The rapidity with which California Bartletts are shipped from the state is due not only to the high degree of perishability of the fruit, but also to the fact that a large part of the fresh fruit is shipped in refrigerated cars over distances from 2,000 to 3,000 miles, requiring as much as 10 days en route to the larger midwestern and eastern markets. Substantial but considerably smaller amounts are also shipped under refrigeration in steamships to the east coast of the United States and to Europe. Intercoastal shipments from San Francisco to New York require about two weeks in transit, while steamship movement to Europe requires about three weeks for the 8,000-mile journey. The combination of perishability and distance from consuming centers, requiring rapid marketing and transportation under refrigeration, is not unique to California Bartletts, but common to all California fresh fruits that are so perishable that they can be stored safely for only a short time.

\section{SEASONALITY IN AUCTION PRICES AND SALES}

Construction of Average Prices.-Average weekly and season's auction prices are constructed from daily data published in the auction catalogs of the fruit auction companies. Before explaining the construction of a season's average price, it is necessary to emphasize that the

\footnotetext{
${ }^{7}$ For location of pear-production areas in California, see the map in: Shear, S. W. Economic aspects of the pear industry. California Agr. Exp. Sta. Bul. 452:30. 1929. (Out of print.) Pear-production areas for the United States are shown on the map on page 11 of the same study.

${ }^{8}$ For the state as a whole, the usual period of maturing and harvesting is about three months; for individual districts, the period varies from two and one half to three months. The period of maturing and harvesting in a single orchard, however, may be as short as two weeks. These estimates are based on examination of shipment data.
} 
weekly prices are based on the daily prices. These daily prices are averages of the prices at which individual sales are made and are weighted by the respective volumes of sales. The weekly averages of daily prices are weighted by the daily volumes of sales; and the season's price, based on the weekly prices, is an average weighted by weekly volume of sales. Such weighted-average prices can be taken to be representative of the respective time periods such as a week or season.

The Auction Market.-Auction prices result from transactions in a market that, in character, closely approaches a perfectly competitive market. Samples of the merchandise designated according to grade and size are available for inspection before buying and selling begins, and no limitations are placed on entry, exit, or participation in the market. No one is obliged either to sell or to buy certain merchandise. The market is open to a sufficiently large number of buyers and sellers so that the entry or withdrawal of one buyer or seller does not significantly influence the price. One important exception to a perfectly competitive market pertains to the merchandise packaged with brand names. To this extent, product differentiation does exist in the minds of buyers and sellers.

Measurement of Seasonal Variation in Prices and Sales.-The date on which the California pear marketing season begins varies from year to year according to the time at which the fruit matures in the earliest producing districts, which in turn depends chiefly upon weather conditions and cultural practices. In constructing indexes of seasonal variation in the volume of sales and prices, the dates on which the different seasons begin must be considered, since all the seasons do not start on the same calendar dates. For the purposes of this study, the week chosen as the significantly initial one in each marketing season is the first week in which at least 2 per cent of the season's total sales in the New York market were sold. For example, in 1926 the first week in which at least 2 per cent of the season's total sales were made ended July 9 ; in 1927 the corresponding first week ended July 22 ; and in 1928 the first marketing week ended July 13. All of the first weeks, as thus determined, are considered together in computing the seasonal index of the first marketing week; and the subsequent weeks follow chronologically.

Figure 1 shows the indexes of seasonal variation in weekly sales and prices on the New York auction market by five-year periods during 19191938 for marketing weeks designated as 1 to 12 in table 13 (p. 298). The indexes of weekly volume of sales were constructed by first expressing the weekly sales of a given season as percentages of the average weekly sales of that season. From these percentages of all the like-numbered weeks was computed an arithmetic average which is considered as the index, or relative, of that week for a given period of years. In computing 
the price indexes of a group of years, the average price of each week is expressed as a percentage of the season's weighted-average price, and an arithmetic average is taken of the relatives of the same numbered weeks of the years included in the group. An advantage of computing the indexes of seasonal variation in the sales and prices in this manner is that the secular and cyclical elements are sufficiently eliminated to place the corresponding weeks on comparable bases.
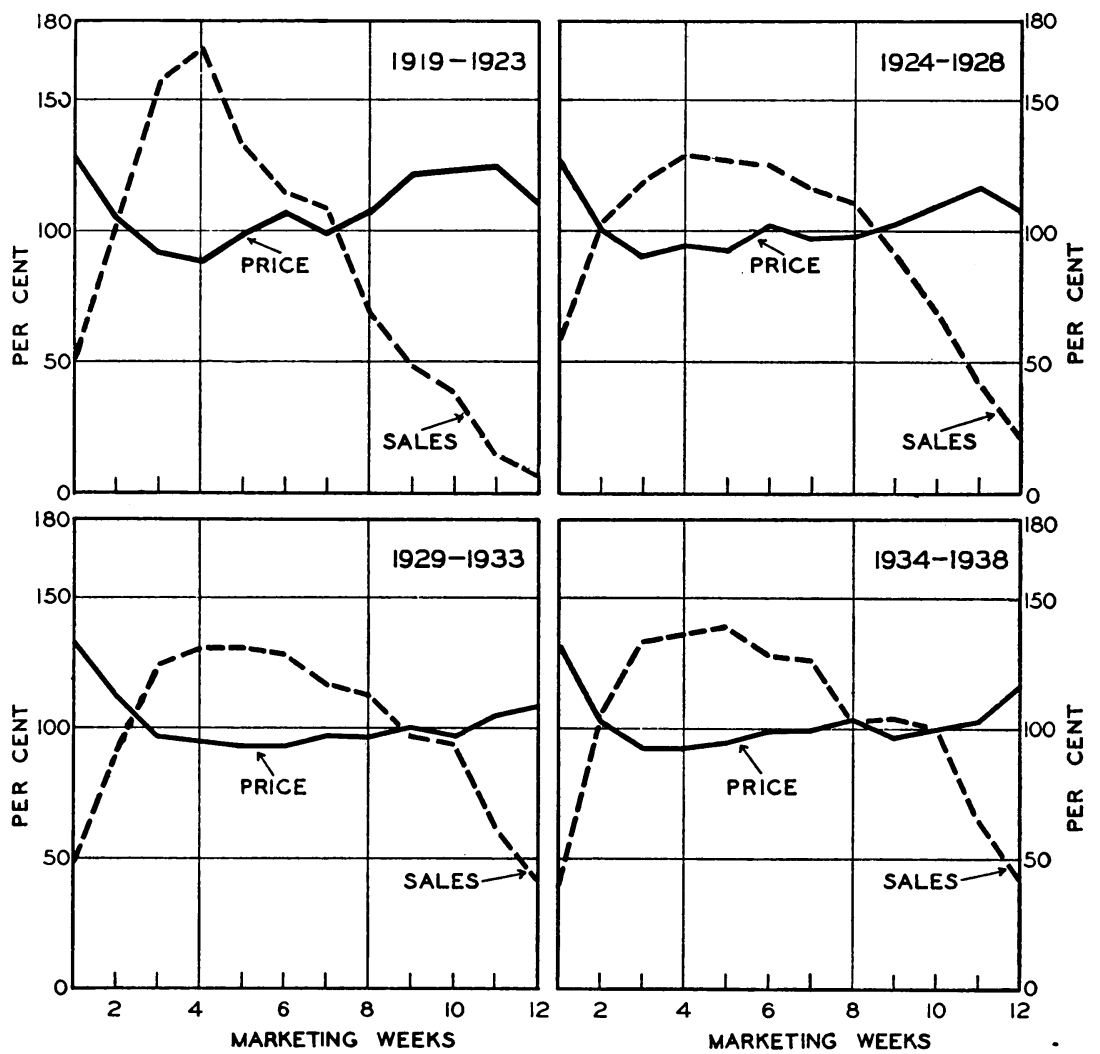

Fig. 1.-Relative weekly New York auction sales and prices of California Bartlett pears, five-year averages, 1919-1938. The marketing weeks of the individual seasons were determined by including those weeks having at least 2 per cent of the season's total.

Data from tables 14 and 15 (p. 301-2).

The very similar patterns of seasonal variation for the three periods from 1924 through 1938 (fig. 1) show an increase in sales from the first week of the season to a maximum in the fourth or fifth week, after which time the volume of weekly auction sales declines. The rate of increase in sales during the first four or five weeks is greater than the rate of decline in sales during the remainder of the season. Although the volume of 
seasonal sales has followed such a general pattern during the past twenty years, a marked and important change in the conformation of the seasonal trend of sales has developed.

The seasonal variation in weekly auction prices follows a pattern which, in general conformation, is inverse to that of sales. The auction prices decline from the first week in the season to a minimum and then rise as the season progresses. However, the average maximum sales and minimum prices occurred in the same weeks, the fourth and fifth respectively, only in the two groups of years 1919-1923 and 1929-1933.

The general pattern of seasonal variation in sales is influenced by the perishability of fresh Bartlett pears. Moreover, the weekly movements of sales and prices are closely related. The causal connection between seasonal variation in the volume of sales and prices may be stated as follows : If the rate of consumption of a commodity is to be adjusted to the rate of output of that commodity, there must be a sufficient inducement for consumers to be willing to accept the output. The conventional explanation of such a concept is that as the quantity of good that is marketed is increased, its price per unit decreases in a certain proportion in order to induce consumers to take the increased output. Such an explanation is closely allied to and largely based on the demand-curve concept, where the demand curve does not shift position or change shape. With the demand and supply curves shifting in opposite directions or in the same direction but in different amounts the situation becomes complex, but more nearly approximates actual market conditions. The demand and supply curves probably change their shapes and positions from day to day according to changes in a large number of variables such as consumers' income, the volume and prices of other commodities, and anticipated future supplies and prices.

Although in general the seasonal variations in sales determine the seasonal variations in prices, at times the reverse may be true. In pears this may be illustrated by reference to the first few weeks of the season which are characterized by relatively high prices. These high prices encourage producers to place their fruit on the market in order to take advantage of the current price situation. At times this causes immature fruit to be shipped for sale before the expected seasonal decline in price occurs. In this sense the seasonal price pattern influences the seasonal sales pattern. This situation, however, is more striking during the latter half of the season. Pears that are ready for shipment during the middle of the season may be held back a short time in the expectation that higher market prices will prevail later. Thus the expected seasonal variation in prices to some extent may influence the distribution of shipments through the season. 
The limited marketing life of Bartletts, together with the fact that an increasing quantity of pears becomes ready for market during the first to the fourth or fifth marketing week of the season, has caused the pattern of seasonal variations in shipments and sales to be largely independent of the seasonal variation in prices. Because California fresh Bartletts are so perishable and the opportunity for storage so limited, the resulting pattern of seasonal variations in the volume of sales or shipments is the chief factor determining the inverse pattern in seasonal variations of prices. Hence, the outcome of attempts to minimize wide

\section{TABLE 1}

Coefficients of Variation of Weekly Sales and Prices of California Bartiate Pears on New York Auction, 1919-1938

\begin{tabular}{|c|c|c|c|c|c|}
\hline Year & Sales & Prices & Year & Sales & Prices \\
\hline 1919. & $\begin{array}{c}\text { per cent } \\
55.7\end{array}$ & $\begin{array}{c}\text { per cent } \\
12.4\end{array}$ & 1929. & $\begin{array}{c}\text { per cent } \\
37.3\end{array}$ & $\begin{array}{c}\text { per cent } \\
8.1\end{array}$ \\
\hline 1920. & 63.1 & 12.5 & $1930 \ldots$ & 25.9 & 14.7 \\
\hline $1921 \ldots \ldots \ldots$ & 70.3 & 19.4 & $1931 \ldots \ldots \ldots \ldots \ldots \ldots$ & 24.5 & 11.3 \\
\hline $1922 \ldots \ldots \ldots \ldots \ldots \ldots$ & 41.9 & 17.1 & $1932 \ldots \ldots \ldots \ldots \ldots \ldots$ & 36.6 & 14.3 \\
\hline $1923 \ldots \ldots \ldots \ldots \ldots \ldots \ldots$ & 56.0 & 13.0 & $1933 \ldots \ldots \ldots \ldots \ldots \ldots$ & 21.0 & 6.0 \\
\hline $1924 \ldots \ldots \ldots \ldots \ldots$ & 37.3 & 5.5 & $1934 \ldots \ldots \ldots \ldots \ldots \ldots$ & 20.1 & 5.3 \\
\hline $1925 \ldots \ldots \ldots$ & 44.7 & 17.2 & $1935 \ldots$ & 41.9 & 11.0 \\
\hline 1926. & 30.9 & 13.3 & $1936 \ldots \ldots \ldots \ldots \ldots \ldots$ & 27.8 & 9.9 \\
\hline $1927 \ldots$ & 36.1 & 14.1 & $1937 \ldots \ldots \ldots \ldots \ldots \ldots$ & 25.7 & 9.8 \\
\hline $1928 \ldots \ldots \ldots \ldots \ldots \ldots$ & 23.6 & 14.3 & $1938 \ldots \ldots \ldots \ldots \ldots \ldots$ & 30.5 & 10.2 \\
\hline
\end{tabular}

Source of data:

The coefficients are based on the data in table 13 (p. 298).

seasonal variations in prices of pears must depend largely upon the feasibility and success of minimizing wide seasonal fluctuations in the volume of Bartlett sales, since the flow of shipments is the only price-influencing factor, other than quality and size, that can be controlled to any extent by shippers.

Trend in Seasonal Variation.-The trend in the magnitude of seasonal fluctuations is shown in table 1 . The coefficients of variation indicate the extent to which the relative variations in weekly sales and prices differ in the various years. In both the sales and prices, from year to year, there are wide fluctuations in the degree of variation; but nevertheless a definite downward trend in the amplitude is evident over the entire period since 1919. Examination of the data for individual years indicates that relative variations in the volume of weekly auction sales followed a sharply declining trend until about 1928, and thereafter flattened out and fluctuated about a horizontal trend. The relative variation in weekly auction prices also generally tended to decrease over the twenty-year period. The decrease before 1929, however, was substantially less than 
the decrease in the relative variation in the volume of weekly sales for the corresponding years. ${ }^{\circ}$

Comparison of Weekly Prices.-A graphical record of the weightedaverage prices of all weeks and seasons from 1920 to 1940 is shown in figure 2. The horizontal dotted lines indicate average prices for the season and the fluctuations about the season's price represent the weekly prices; this clearly indicates the extent to which the weekly prices are represented by the season's weighted-average price. The figure also shows three important types of price movements-secular, cyclical, and seasonal-and it facilitates comparison of price patterns of the different years.

The weekly price record of California Bartlett pears illustrates the typical price behavior of a commodity characterized by the following elements : perishable and not physically adapted to storage over long periods; a marked seasonal variation in readiness for the market and hence in movement of supplies; rapid marketing over a period as short as three months; a semiluxury good to most and a luxury to many consumers; a nonstaple good that is relatively unimportant in diets; a good whose quantity of marketable supply, whose condition, and, to some extent, whose demand are dependent upon the variations of natural phenomena such as weather conditions.

Changes in the amplitude of fluctuations in weekly Bartlett prices are shown in figure 3 in a manner different from those in figures 1 and 2 . The relative prices shown in figure 3 for weeks or groups of weeks are expressed as percentages of the weighted-average prices of the respective seasons. The top panel labeled "through week 2," shows for each year separately the percentage that the weighted-average price through the second week is of the corresponding weighted-average price for the whole season. With few exceptions the prices for early Bartletts have

${ }^{\circ}$ During recent years marketing agreements were set up partly to regulate the distribution of interstate shipments of California Bartletts throughout the season, and consequently might be expected to have influenced the seasonal patterns of auction sales and prices. Formal marketing agreements on interstate shipments of California Bartletts operated in 1935, 1936, 1937, and 1939, and during the 1934 season there was some voluntary shipper effort to restrict shipments during the weeks of maximum rate of movement. Although there was no formal marketing agreement in the 1938 scason, through an informal agreement with the Agricultural Adjustment Administration and the Federal Surplus Commodities Corporation, a shipment holiday was put into effect for a short time. Reference to table 1 indicates that the two years previous to the agreements were characterized by seasonal variations smaller in relative magnitude than the years in which the agreements were in force. In the season of 1938, when there was no formal marketing agreement, seasonal fluctuations in the volume of sales were greater than in 1937, but less than in 1935 when there was an agreement. The magnitude of seasonal fluctuations in auction prices was practically the same in 1938 as in the three previous years when formal agreements were functioning; whereas in 1933 and 1934 seasonal variations were relatively less in magnitude than in any subsequent years, whether with or without marketing agreements. 

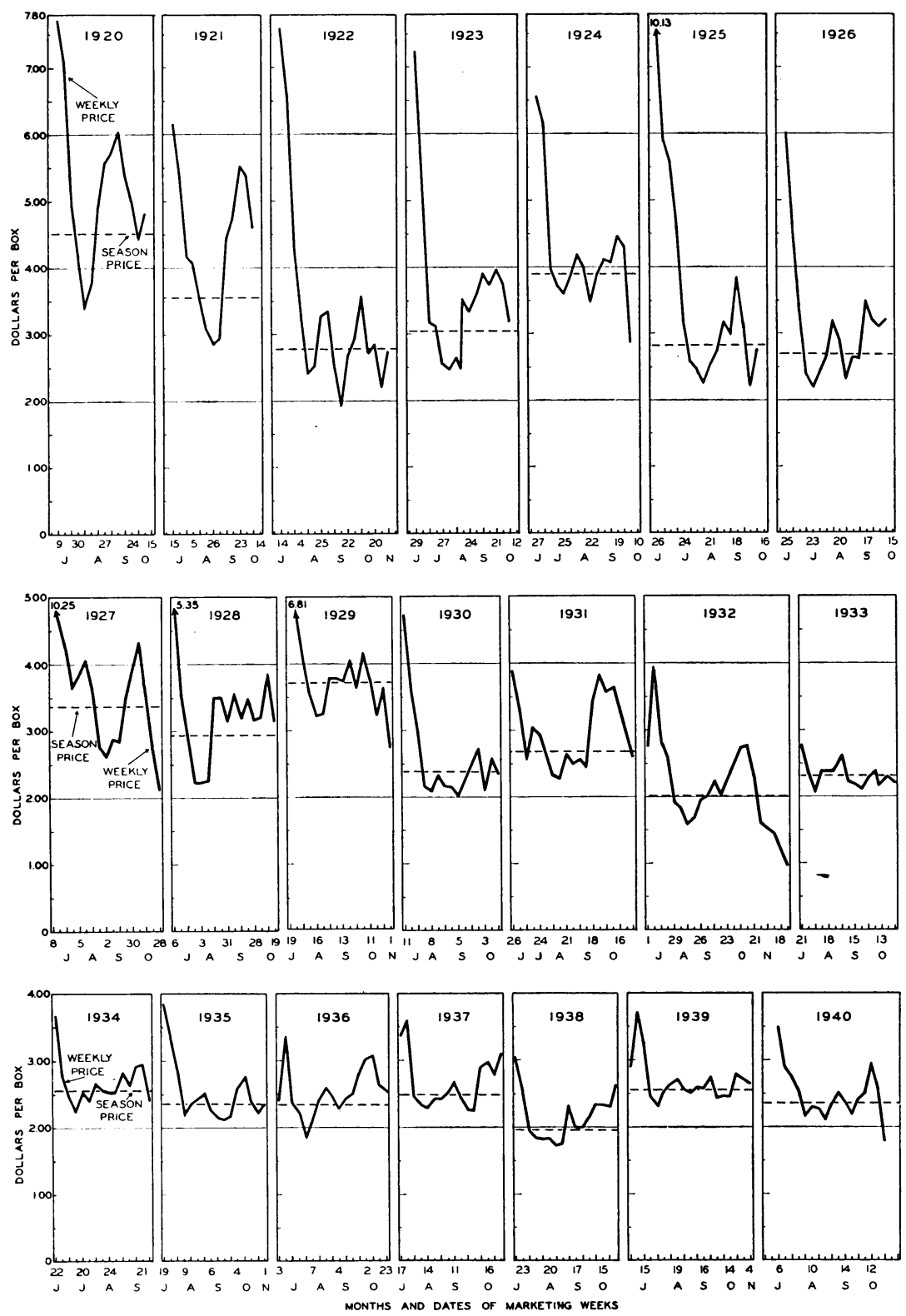

Fig. 2.-Weekly and season's average New York auction prices of California Bartlett pears, 1920-1940.

Data from table 13 (p. 298). 
been noticeably higher than the season's average price, but there has been an appreciable decrease in the premium on them in recent years. Since 1930 there is noticeable a tendency for the average price through the
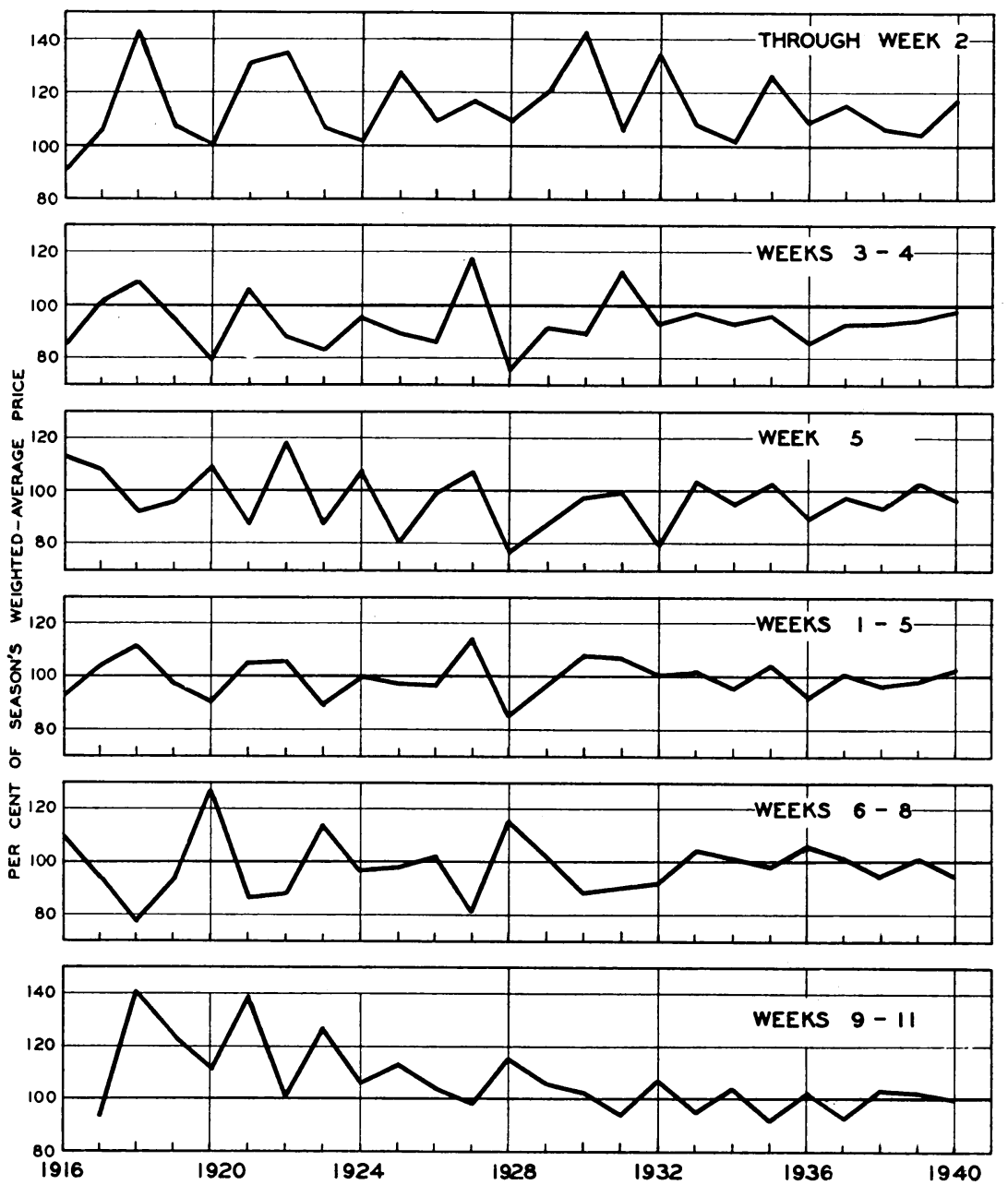

Fig. 3.--Relative weekly New York auction prices of California Bartlett pears by weeks and groups of weeks, 1916-1940.

Based on data in table 16 (p. 303).

second week of the season to be closer to the season's weighted-average price than was characteristic of earlier years. Prices during the third and fourth weeks (usually periods of heavy marketing) have generally been below the season's average, but since 1930 they have not been relatively as low as formerly. 
The third panel in figure 3 shows that prices for the fifth week have tended to fluctuate around the season's average, but that since 1930 the relative deviations have been smaller than previously. Much the same tendency is characteristic of average prices through the fifth week except that they more nearly equal average prices for the whole season than do prices for any other period of weeks shown in figure 3. Prices for weeks six to eight have consistently tended to fluctuate around the season's average, with a noticeable decrease in amplitude since 1930 . The greatest and perhaps most significant change in relative weekly prices, however, has occurred in late Bartletts. The bottom panel in figure 3 clearly shows that from 1918 to 1930 prices in weeks nine to eleven greatly decreased relative to season's weighted-average prices. After 1930 weekly prices of late Bartletts have closely approximated the season's weighted-average price.

Analysis of absolute deviations from season's prices, given in table 16 (p. 303), indicates tendencies similar to those shown in figure 3. The expression of weekly prices as percentages of season's prices has the merit of making the weekly price deviations of the separate years relatively comparable, since the season's prices vary from year to year, partly according to the general price level. Obviously, a deviation of $\$ 0.10$ from the season's weighted-average price of $\$ 2.01$ in 1932 is not comparable to a deviation of $\$ 0.10$ from the season's weighted-average price of $\$ 4.51$ in 1920. The relative data presented in figure 3 and the absolute data in table 16 both show that weekly price deviations from the season's prices have been substantially smaller since 1930 than in earlier years. ${ }^{10}$

Comparison of Weekly Sales.-The volumes of weekly auction sales as a percentage of the season's total sales for various weeks and groups of weeks are shown in figure 4 . This figure shows that the season's sales have tended to be less concentrated in the first and second thirds of the season and more concentrated in the last third of the season, especially weeks nine to eleven. Furthermore, the variations in any given part of the season were much greater before 1925 than they have been since then. This smoothing of the relative distribution of sales through the season in recent years seems to be reflected in a somewhat corresponding decrease in relative variations in weekly prices (p. 240). In fact, the relations between weekly prices and sales substantiate the conclusions suggested earlier (p. 243) that the patterns of seasonal variation of weekly prices and sales have progressively changed so that since 1930 individual weeks of the season do not vary among themselves so much as during the 1920's.

\footnotetext{
${ }^{10}$ This tendency does not appear to be a direct result of pear marketing agreements which were in force during the 1935,1936 , and 1937 seasons, since the tendency is apparent in earlier years and also in 1938 when there was no formal marketing agreement on Bartletts.
} 

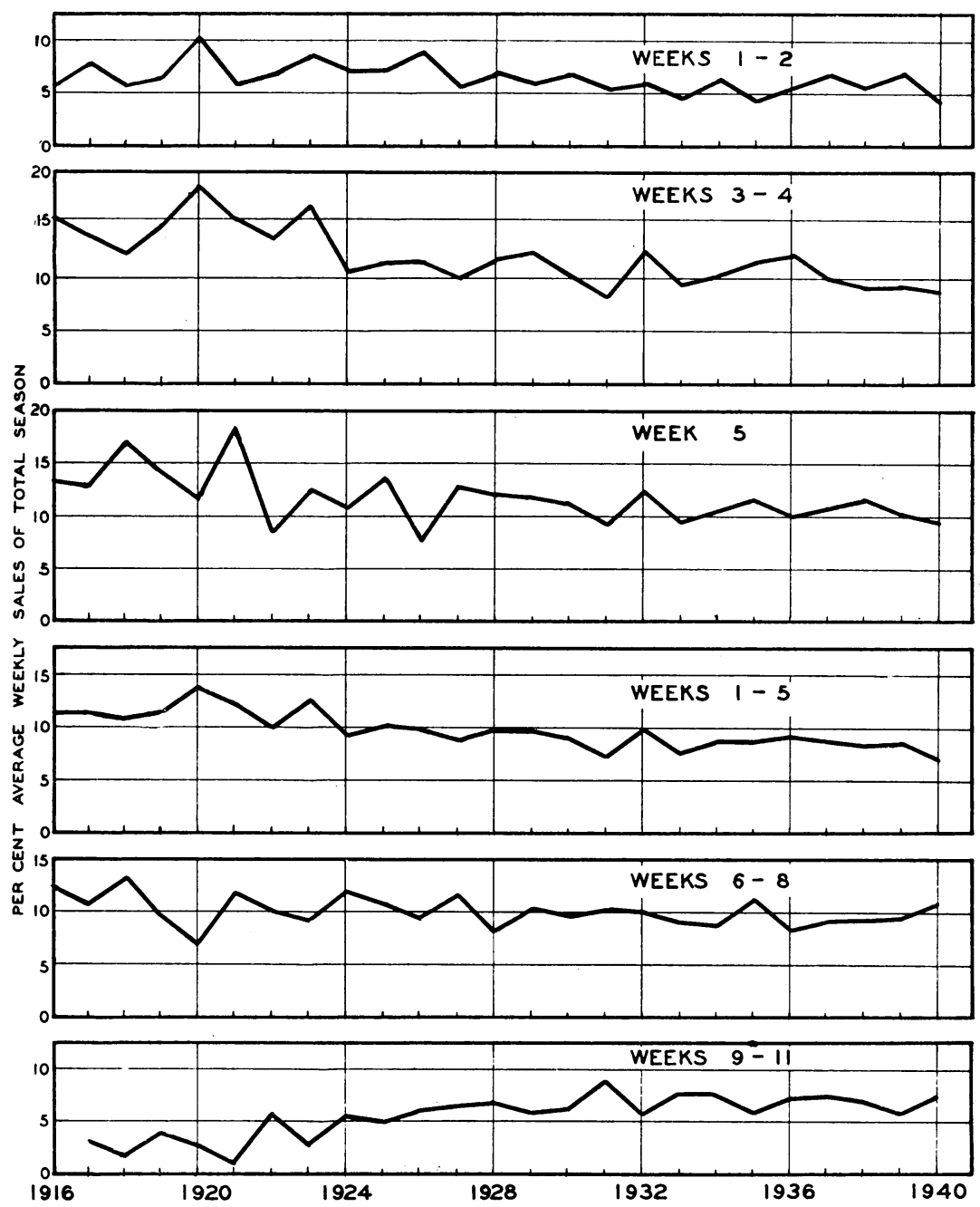

Fig. 4.-Relative weekly New York auction sales of California Bartlett pears by weeks and groups of weeks, 1916-1940.

Data from table 17 (p. 304).

Explanations of Change in Weekly Price Variation.-The question arises as to why the fluctuations in weekly prices have gradually decreased in relative amplitude of variation. This trend is largely due to a diminishing in the fluctuations of weekly auction sales associated with a smoother flow of shipments throughout the season. One may question why such a gradual change has occurred in the volume of weekly ship- 
ments and sales. A change in the geographical distribution of the producing areas may be one explanation. The production of California Bartletts over a wider and more dispersed area has resulted in a shift in the relative importance of the early, midseason, and late Bartlett-producing districts of the state. The dovetailing and overlapping of shipping periods in the various districts may have resulted in a more even distribution of shipments and sales through the season. Another reason may be that through experience growers and shippers have learned to regulate their shipments more evenly through the season. There is less tendency to ship too early in the season, for experience may have taught that small, immature fruit not only is received unfavorably on the markets but also adversely affects the prices received for subsequent shipments. There is some evidence in this direction since auction sales in the earliest weeks of the season, that is, through the second week, are relatively smaller in volume since 1925 than they were earlier. The most significant shift in shipments and sales, however, is the large increase in the proportion moving during the latter part of the season, in the ninth through the eleventh weeks. The substantial premiums paid for late California Bartletts fifteen years ago undoubtedly were the major stimulus that led to a relatively great increase in the acreage, production, shipments, and sales of late California Bartletts. The greater use of coldstorage facilities is probably also partly responsible for the relative increase in auction sales of late California Bartletts. Furthermore, the increased production of Bartletts in the Pacific Northwest and of other varieties of pears on the Pacific Coast marketed when California late Bartletts are shipped also appears to be a factor partially responsible for the decline in the relative prices of California Bartletts sold during the last third of the season.

Systematic Variation in Weekly Prices and Sales.-In the discussion and analysis of seasonal variations in sales and prices, the rate of marketing California Bartletts has been pointed out (p. 241) as one of the influences determining the seasonal pattern in weekly auction sales and prices. In this connection it is also necessary to investigate whether the relations between auction sales and prices vary systematically from week to week. In order to place the correspondingly designated marketing weeks of the various years on approximately comparable levels, weekly relative sales and prices will again be used instead of the actual sales and prices. In the subsequent analysis, all of the designated first marketing weeks of the seasons 1924 to 1938 are considered together, all of the second weeks, and in a similar manner all of the following ten weeks. This will indicate the association between relative sales and prices in the various weeks as the season progresses. Furthermore, the degree of association between 
the weekly sales and prices can be measured statistically, and the extent to which the twelve marketing weeks differ in a measurable degree can be determined.

Has there been some recognizable pattern indicative of changes in the degree of association between auction sales and prices as the season advances, for the period 1924-1938 as a whole? Table 2 gives some indications of the degree to which auction sales and prices have been associated in the twelve marketing weeks.

The correlation coefficients do not indicate that as the season progresses from week to week the degree of linear association between sales

\section{TABLE 2}

Coefficients of Correlation Between Relative Weekly Sales and Prices of California Bartlett Pears on the New York Auction Market, by Marketing WeEKs, 1924-1938

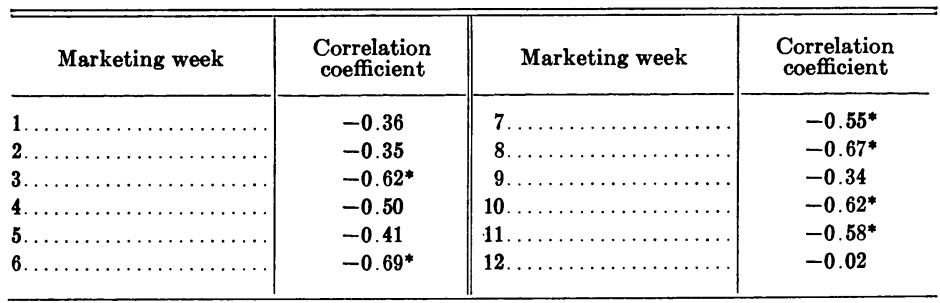

* The correlation coefficients designated by an asterisk exceed the 5 per cent level of statistical significance; the chances are less than 5 in 100 that correlation coefficients as high as those, or higher, would occur in a random sample from a population in which the two variables are not correlated. For thirteen degrees of freedom, $r=0.51$ at the $P=0.05$ level of significance.
the two variables are not

Source of data:

Based on data in tables 14 and 15 (p. 301-2).

and prices changes according to some definite pattern. Both the fourth and fifth weeks are characterized by lower degrees of association than either the third or sixth week. The ninth week is characterized by a significantly smaller degree of association than either the eighth, tenth, or eleventh weeks. The highest degree of association between sales and prices apparently occurs in the sixth week, which in most seasons is after the week of maximum sales.

More significant than the correlation coefficients are the statistical measures referred to as regression coefficients. The regression coefficients between sales and prices, with the former considered as the independent variable, indicate the amount and direction of linear change in the auction price that accompanies a change of one unit in the auction sales. Table 3 lists such regression coefficients, one for each of the twelve marketing weeks of the season. Comparison of the computed weekly regression coefficients gives an indication of the extent to which the 
price varies with changes in volume of sales in the different weeks. ${ }^{11}$ As may be expected, the weekly auction sales and prices generally move in opposite directions. Furthermore, the relative amount of price change that accompanies a corresponding change in the volume of sales varies from week to week. But the price effect appears to be independent of the week of the season; the price effect of the first and third weeks is almost identical with that of the sixth and eighth weeks. The lack of significant association at the end of the shipping season may be chiefly due to the influences of the Pacific Northwest Bartletts and other pears that are then on the market in abundance.

TABLE 3

Average Percentage Change in Price per Box Associated with a Change of 1 Per Cent in Sales, by Marketing Weeks, 1924-1938

\begin{tabular}{|c|c|c|c|}
\hline Marketing week & $\begin{array}{l}\text { Regression } \\
\text { coefficient }\end{array}$ & Marketing week & $\begin{array}{l}\text { Regression } \\
\text { coefficient }\end{array}$ \\
\hline $1 \ldots \ldots \ldots \ldots \ldots \ldots$ & $-0.38 \pm 0.28^{*}$ & $7 \ldots \ldots$ & $-0.42 \pm 0.18^{*}$ \\
\hline $2 \ldots \ldots \ldots \ldots \ldots \ldots$ & $-0.23 \pm 0.17$ & $8 \ldots$ & $-0.39 \pm 0.12$ \\
\hline $3 \ldots \ldots$ & $-0.38 \pm 0.13$ & $9 \ldots$ & $-0.28 \pm 0.22$ \\
\hline $4 \ldots$ & $-0.33 \pm 0.16$ & $10 \ldots$ & $-0.28 \pm 0.09$ \\
\hline $5 \ldots$ & $-0.23 \pm 0.14$ & $11 \ldots$ & $-0.26 \pm 0.10$ \\
\hline $6 \ldots \ldots \ldots \ldots$ & $-0.37 \pm 0.11$ & $12 \ldots$ & $-0.01 \pm 0.19$ \\
\hline
\end{tabular}

* Standard error.

Source of data:

Based on data in tables 14 and 15 (p. 301-2).

Table 3 gives some indication of the price sensitivity of the auction market in the various weeks of the season. There is some basis for judging the extent to which price changes are more sensitive to increases or decreases in sales in the various weeks. Again there is no definite pattern in the statistical measures and little statistical evidence that as the season progresses and as weekly sales increase to a maximum and then taper off, the weekly price changes that accompany a certain change in the sales follow a definite and consistent pattern. In other words, there is little basis for stating that in the weeks of the first half of the season a given relative increase in weekly sales would be accompanied by smaller or larger corresponding price change than in the weeks of the second half of the season. Thus, a variation in the volume of weekly sales in the first half of the marketing season appears to have no significantly different price effect than a variation in the volume of sales in the second half of the season. In fact, during the last week of the market-

\footnotetext{
${ }^{11}$ Since the prices and sales are expressed as percentages of season's weightedaverage prices and season's average weekly sales, respectively, the regression coefficients measure the price change, in percentage points, that on the average accompany a change of 1 per cent in the volume of weekly auction sales.
} 
ing season, changes in auction prices of California Bartletts are largely independent of changes in volume of auction sales.

\section{PRICE RELATIONS BETWEEN SIZES}

In the section "Seasonality in Auction Prices and Sales" weekly and annual weighted-average prices of all sizes of California fresh Bartlett pears have been considered. Here some attention is given to the prices of individual sizes. The price behavior of various sizes is described briefly, showing how, in certain years, prices of different sizes vary among themselves.

Season's Prices of Individual Sizes.-The extent to which season's weighted-average prices of all sizes include heterogeneous kinds of Bartlett pears is evident when the sales and prices of various sizes are examined. Pears are not an economically homogeneous commodity, and even California Bartletts are not strictly homogeneous with respect to quality and size. The diversity in size and quality is reflected in prices of the individual sizes. Weighted-average prices of all sizes, such as have been used in the foregoing pages, obscure the price relations between various sizes. Although such weighted-average prices are extremely useful and entirely adequate for many purposes, for some purposes the prices of individual sizes must be considered separately. Here, however, the discussion will go no further than to indicate briefly the extent of divergence between the prices of different sizes of California Bartletts sold on the New York auction market. The discussion between prices and sizes is necessarily limited to the recent seasons because data on sizes are not available before 1936 .

Since various sizes of pears are approximately equally useful in satisfying consumers' wants, there are some grounds for expecting various sizes to compete with each other in sales on the auction markets. One might expect such intersize competition to result in a tendency for prices of the several sizes to bear some constant ratio to each other. The price per box of a certain size of California Bartletts may be influenced not only by the supply of that size but also by the supplies and prices of the various other sizes on the market. Very few purchasers insist on obtaining a particular size regardless of the relation of its price to those of other sizes. Certain sizes, however, may be preferred for home canning, and other sizes may be preferable for sale by the dozen on fruit stands. There are grounds for expecting that, in general, a high degree of competition prevails among the various sizes and that their prices are closely related.

Pear sizes are designated by the number of pears packed in a standard box. The usual range in the number of pears per box is from 60 to 210, 
with the majority of the fruit falling in the sizes between 110 and 195 to the box. The individual sizes run as follows :

$\begin{array}{lll}\text { larger than } 60 \text { 's } & 100 \text { 's } & 165 \text { 's } \\ 60 \text { 's } & 110 \text { 's } & 180 \text { 's } \\ 70 \text { 's } & 120 \text { 's } & 195 \text { 's } \\ 80 \text { 's } & 135 \text { 's } & 210 \text { 's } \\ 90 \text { 's } & 150 \text { 's } & \text { smaller than } 210 \text { 's }\end{array}$

Between adjacent sizes the difference in pears per box is 10 from 60 's to 110 's and 15 from 110's to 210's. One can scarcely detect the difference between the pears in two adjacent sizes, such as 80 's and 90 's, but can easily detect it between those several sizes apart.

TABLE 4

Season's Weighted-Average Prices and Sales of California Bartlett Pears on THE New York Auction Market, by Sizes, 1936-1939

\begin{tabular}{|c|c|c|c|c|c|c|c|c|}
\hline \multirow{2}{*}{ Size } & \multicolumn{2}{|c|}{1936} & \multicolumn{2}{|c|}{1937} & \multicolumn{2}{|c|}{1938} & \multicolumn{2}{|c|}{1939} \\
\hline & $\begin{array}{c}\text { Price } \\
\text { per box }\end{array}$ & Sales & $\begin{array}{c}\text { Price } \\
\text { per box }\end{array}$ & Sales & $\begin{array}{c}\text { Price } \\
\text { per box }\end{array}$ & Sales & $\begin{array}{c}\text { Price } \\
\text { per box }\end{array}$ & Sales \\
\hline & dollars & 100 boxes & dollars & 100 boxes & dollars & 100 boxes & dollars & 100 boxes \\
\hline $\begin{array}{l}70 \text { 's. } \\
80 \text { 's. }\end{array}$ & $\begin{array}{l}2.29 \\
2.29\end{array}$ & $\begin{array}{r}5 \\
24\end{array}$ & $\begin{array}{l}2.38 \\
2.28\end{array}$ & $\begin{array}{l}15 \\
43\end{array}$ & $\begin{array}{l}2.06 \\
2.01\end{array}$ & $\begin{array}{l}1 \\
7\end{array}$ & $\begin{array}{l}2.25 \\
2.39\end{array}$ & $\begin{array}{l}1 \\
6\end{array}$ \\
\hline 90 's. & 2.29 & 57 & 2.25 & 98 & 2.05 & 25 & 2.46 & 22 \\
\hline 100 's. . & 2.22 & 151 & 2.23 & 269 & 2.01 & 93 & 2.46 & 59 \\
\hline 110 's. . & 2.21 & 239 & 2.24 & 376 & 1.93 & 174 & 2.49 & 105 \\
\hline 120 's... & 2.22 & 521 & 2.30 & 793 & 1.96 & 494 & 2.41 & 323 \\
\hline 135 's .... & 2.30 & 1,361 & 2.39 & 1,723 & 1.99 & 1,228 & 2.48 & 992 \\
\hline 150 's. & 2.36 & 2,150 & 2.53 & 2,271 & 1.96 & 2,076 & 2.58 & 1,748 \\
\hline 165 's. . & 2.36 & 2,256 & 2.63 & 1,791 & 1.96 & 2,384 & 2.60 & 1,927 \\
\hline 180 's $\ldots \ldots \ldots \ldots$ & 2.42 & 1,691 & 2.72 & 846 & 1.96 & 1,828 & 2.61 & 1,671 \\
\hline
\end{tabular}

Source of data:

Based on data in tables 18 and 19 (p. 305-7).

Study of the prices of different sizes of California Bartletts reveals the great extent to which they are physically and economically heterogeneous. The price relations between various sizes resemble considerably the price relations between different commodities. One is impressed with the notion that in some instances it is necessary to consider individual sizes as special cases of a family-California Bartlett-which is only one variety of pears.

Table 4 gives season's average prices and sales of California Bartletts by sizes on the New York auction market for the four seasons 1936-1939. In 1936 every one of the sizes listed sold at a premium over the 110's. The premium ranged from only 1 cent a box for 100's and 120's to 21 cents for 180's. In the sizes which composed the large majority of sales135 's to 180 's - the price per box tended to increase as the sizes decreased. The following year, 1937, was characterized by a similar pattern of relation between sizes and prices. The minimum price that season was for 
100 's and the premiums ranged from 1 cent for 110's to 49 cents for 180 's. In 1937 , prices per box of the sizes composing the majority of pears sold also tended to increase as the sizes decreased; this tendency was even more marked in 1937 than in the previous years. During 1936, and particularly during 1937 , auction purchasers apparently preferred the smaller sizes of pears over the season as a whole. During the 1939 season smaller pears also generally were sold at a premium over the larger sizes, broadly similar to the price-size relations during 1936 and 1937.

In 1938 the relation between prices and sizes, however, was markedly different from that in 1936, 1937, and 1939. The larger sizes, 70's, 80's, 90 's, and 100's, obtained a premium over the medium and smaller sizes. In fact, there were very small price differences in the sizes ranging from 120 's to 180 's. In 1938 auction-market buyers were not willing to pay premium prices for the medium and smaller California Bartletts. Table 4 indicates the divergencies in the sales and prices of various sizes of pears. No definite relation is apparent between the relative volumes of the different sizes and their prices. But the price differentials between sizes also reflect other varying influences such as firmness, maturity, and color. Thus, weighted-average season's prices of all sizes obscure the characteristics of the individual sizes as indexes of fruit prices obscure the price behavior of the index components.

Weekly Prices of Individual Sizes.-Price differentials between pear sizes are even more marked in weekly prices than in season's prices. ${ }^{12}$ In the 1936 season, the smaller sizes, 150's, 165's, and 180's, sold at relatively low prices during the second and third weeks, apparently because of the relatively larger supplies of the smaller pears. But in the following weeks a change in the price-size relation is noticeable; the small sizes, 165's and 180's, sold at a slight premium over the medium. The general pattern of the fifth week resembles that of the fourth; but the smaller sizes enjoyed a greater premium over the medium and large. The price-size relations of the weeks seven to twelve, inclusive, largely resemble each other. A characteristic of the price-size relation is that as the season advanced small sizes were sold at a premium over medium sizes, which in turn received a premium over the large sizes. From the beginning to the end of the season the price-size pattern gradually changed, and in the last third of the season the relations between size and price were inverse to those during the first two weeks of the season.

The relations between weekly prices and sizes in 1937 closely followed the patterns of the previous year. The outstanding difference between the two years is that in 1937 smaller sizes were sold at a premium earlier

\footnotetext{
${ }^{12}$ Price and sales data by sizes for all the weeks in the four seasons 1936, 1937, 1938, 1939 are given in tables 18 and 19 (p. 305-7).
} 
in the season than in 1936. But in both years there was a strong tendency after the season was well under way for the price per box gradually to increase as the pear size decreased. In 1938 the relation between size and price was different from that of 1936 and 1937. The smaller sizes were at a discount during the first half of the season, and subsequently sold at a premium over the medium sizes. But the larger sizes, 90's and 100 's, also sold at a premium over the medium sizes in most weeks of the season. In 1938 there was no strong tendency in most weeks, as in 1936 and 1937, for the box price gradually to increase as the pear sizes decreased. During 1939 the price-size relations for individual weeks roughly corresponded to the relations in 1936 and 1937. Examination of the available data on the sales and prices of various sizes in the four seasons indicates only a tenuous and unreliable tendency for the price differentials between sizes to be determined by the relative volume of sales of those sizes. It is highly probable that varying qualities, of which there is no objective measure, are also instrumental in determining the price relations between sizes. But study of weekly price data on sizes indicates the extent to which weekly weighted-average prices of all sizes include what are in fact economically and physically nonhomogeneous commodities.

Seasonal Variation in Prices of Particular Sizes.-Figure 5 shows the seasonal trends in the prices of three different sizes of pears for 1936 to 1939. The three sizes, 100's, 135's, and 180's, are shown for two reasons : first, they represent large, medium, and small pears, respectively; second, for sizes larger than 100's or smaller than 180's there are no continuous weekly prices. Examination of the seasonal trends in the weekly prices of the three sizes emphasizes certain relations between size and price discussed above (p. 251); in addition there is an indication of the extent to which the seasonal variations in the prices of the three sizes are similar in pattern. Figure 5 clearly shows that during the heavy marketing weeks of the 1936 and 1937 seasons the weekly prices varied inversely with the three sizes ; the small pears, 180's, generally were sold at prices with a premium over the medium and large; the large pears, 100's, sold at prices with a discount under the medium and small. In the very early and late weeks of the 1936 and 1937 seasons, there was no consistent relation between size and weekly prices. In the 1938 and 1939 seasons small pears, 180's, did not consistently receive a premium. The marked relation between price and size that characterized the 1936 and 1937 seasons did not hold during the 1938 season. The patterns of seasonal variation in the weekly prices of the three sizes, 100's, 135's, and 180's, were broadly similar in conformation and resembled the pattern of seasonal variation in the weighted-average prices of all sizes. 
At present it cannot be explained fully why in some years, as 1936 and 1937, small sizes consistently sold at a marked premium, and in another year, 1938, there was a marked change in the relation between size and price. Examination of the data on supplies of the various sizes does
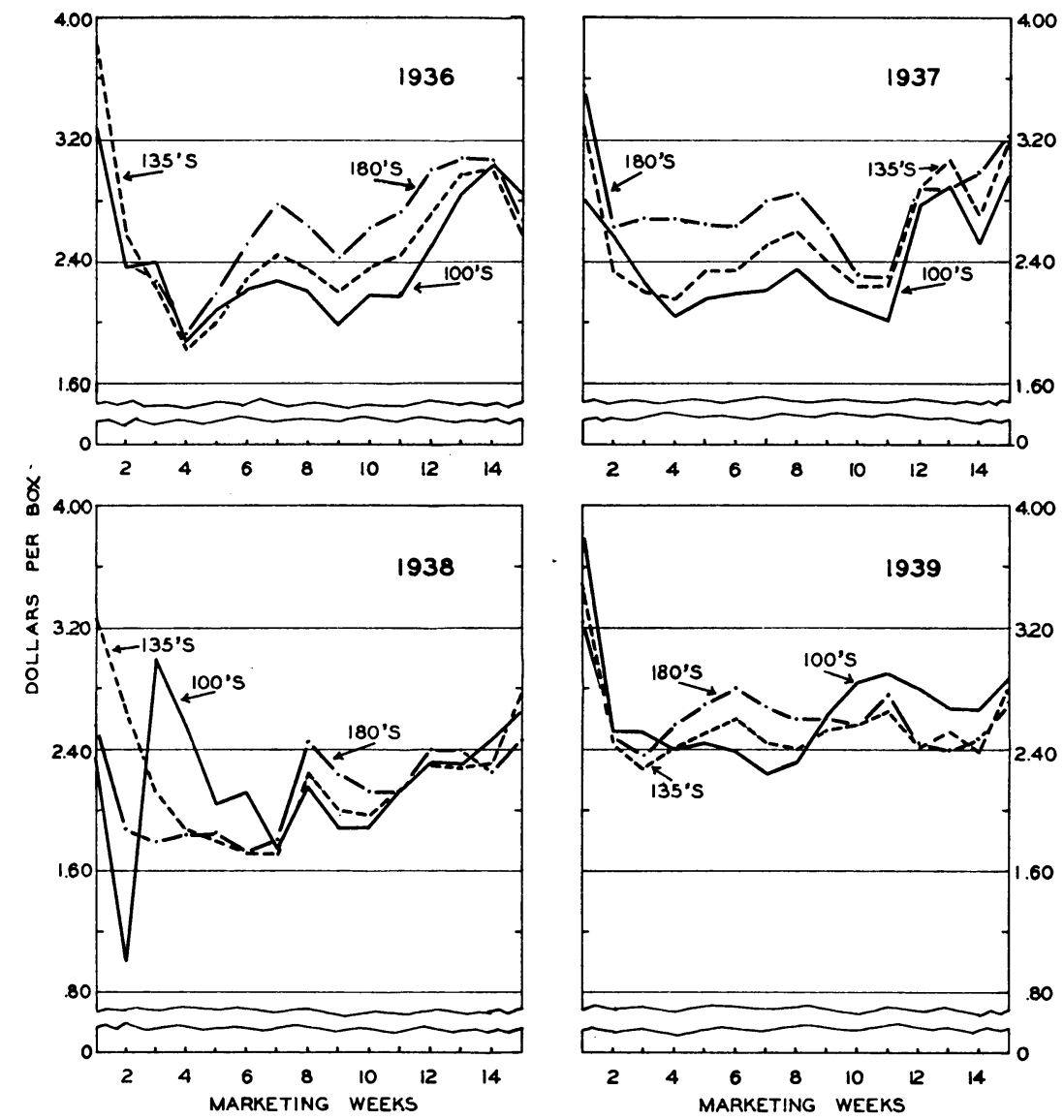

Fig. 5.-Weekly New York auction prices of California Bartlett pears by certain sizes, 1936-1939.

Data from table 18 (p. 305).

indicate that the prices of individual sizes are influenced in some degree by their supplies and those of other sizes. But relative volumes of supplies of various sizes do not wholly explain their relative prices. It may be that for various reasons consumers' preferences may change from certain sizes in one year to other sizes in another year. In addition, if there is some relation between size and quality, such relation may help to account for the relations between price and size. This complex relation between size, quality, and price is a subject that merits more study, but 
the lack of adequate data on prices of various qualities of California Bartletts is a barrier to present extension of the analysis. At present only the extent to which prices of individual sizes differ among themselves can be indicated. Hereafter only the weighted-average prices of all sizes will be considered, since the relations to be discussed may be adequately examined by utilizing such prices.

The statistical data used in the preceding analyses pertain to the New York fruit auction market, the largest in the country. A presumption may be made that the relations between volume of sales, prices, and sizes in New York are also characteristic of other markets. But it is pertinent to investigate whether New York Bartlett prices are representative of those in other auction markets where substantial quantities of pears are sold.

\section{PRICE RELATIONS BETWEEN AUCTION MARKETS}

California Bartletts consumed in fresh form, except those used fresh in the state (about 12 per cent of harvested production during 1934 1938), are sold chiefly in auction and private markets in the Middle West and the East. The auction markets located in the large eastern cities receive the bulk of shipments, and the New York auction handles between 40 and 50 per cent of the total volume handled in all twelve auction markets. Largely because of the importance of New York as an outlet, New York auction prices are usually considered as representative of fresh-pear prices in general. In addition, New York prices are usually referred to since the most complete available records of Bartlettpear prices are those pertaining to the New York fruit auction market. But the auction markets in other large centers of population and trade, such as Boston, Philadelphia, Chicago and Detroit, are important.

The data in table 5 indicate the extent to which New York dominates total auction-market sales. Since 1932 the relative importance of the New York auction has declined; whereas Philadelphia and Cincinnati, among other small markets, have increased their relative volume of sales. The distribution of sales among the various auction markets raises the question as to what extent New York prices are representative of those in other markets. In answering this question it is necessary to distinguish between different time units; weekly prices and season's prices must be considered separately.

\section{SEASON'S AVERAGE PRICES IN MAJOR AUCTION MARKETS}

Season's average prices in seven auction markets are available from the 1920 season to date. To compare the annual prices in different markets, the four markets selling the largest quantity of California Bart- 
letts-New York, Chicago, Philadelphia, and Boston-will be used. The freight rate from California to the three Atlantic seaboard markets is $\$ 1.63$ per 100 pounds for a minimum carload weight of 27,500 pounds, but to Chicago the freight rate is $\$ 1.63$ per 100 pounds for a minimum carload of 26,000 pounds. ${ }^{13}$ The season's average prices in dollars per box in the four chief auction markets from 1920 through 1940 are given in table 20. The year-to-year changes in the prices in the four markets are similar in direction and approximately of the same amount. Such a

TABLE 5

Distribution of Sales of California Bartlett Pears BY AUCTION MARKETS, 1932-1940

\begin{tabular}{|c|c|c|c|c|c|c|c|c|c|}
\hline Auction market & 1932 & 1933 & 1934 & 1935 & 1936 & 1937 & 1938 & 1939 & 1940 \\
\hline New York....... & $\begin{array}{c}\text { per cent } \\
47.6\end{array}$ & $\begin{array}{c}\text { per cent } \\
48.1\end{array}$ & $\begin{array}{c}\text { per cent } \\
46.7\end{array}$ & $\begin{array}{c}\text { per cent } \\
47.9\end{array}$ & $\begin{array}{c}\text { per cent } \\
\quad 43.0\end{array}$ & $\begin{array}{c}\text { per cent } \\
40.0\end{array}$ & $\begin{array}{c}\text { per cent } \\
43.6\end{array}$ & $\begin{array}{c}\text { per cent } \\
\quad 41.2\end{array}$ & $\begin{array}{c}\text { per cent } \\
39.2\end{array}$ \\
\hline Chicago.... & 14.7 & 17.1 & 13.9 & 14.7 & 14.3 & 15.7 & 14.0 & 15.1 & 14.8 \\
\hline Boston. . & 9.5 & 8.1 & 10.6 & 9.8 & 10.5 & 10.3 & 10.3 & 11.2 & 11.5 \\
\hline Philadelphia. & 9.2 & 9.5 & 11.4 & 10.8 & 11.2 & 10.6 & 11.0 & 11.6 & 11.2 \\
\hline Pittsburgh..... & 3.0 & 2.5 & 3.2 & 2.7 & 3.5 & 4.0 & 3.1 & 2.6 & 3.8 \\
\hline Cleveland. & 2.8 & 2.6 & 2.3 & 2.5 & 3.2 & 4.1 & 3.2 & 3.4 & 4.2 \\
\hline Baltimore. . & 2.2 & 2.3 & 2.7 & 2.4 & 2.5 & 3.2 & 2.7 & 3.7 & 3.5 \\
\hline St. Louis. & 2.0 & 2.1 & 1.8 & 1.4 & 2.0 & 2.3 & 2.4 & 2.1 & 2.2 \\
\hline Cincinnati. & 1.5 & 1.7 & 1.8 & 1.7 & 2.0 & 2.3 & 2.4 & 2.3 & 2.6 \\
\hline Minneapolis.. & 2.7 & 2.4 & 0.8 & 1.9 & 2.3 & 2.5 & 2.8 & 2.8 & 2.7 \\
\hline St. Paul... & 1.8 & 1.1 & 1.6 & 1.2 & 1.7 & 1.6 & 1.8 & 1.8 & 1.5 \\
\hline Detroit.......... & 3.0 & 2.5 & 3.2 & 3.0 & 3.8 & 3.4 & 2.7 & 2.2 & 2.8 \\
\hline Total. & 100.0 & 100.0 & 100.0 & 100.0 & 100.0 & 100.0 & 100.0 & 100.0 & 100.0 \\
\hline
\end{tabular}

Source of data:

Based on data in table 21 (p. 310).

relation is not unusual and may be expected from experience and from widely accepted price theory, since each market is highly competitive, and the trade in one market quickly becomes aware of the price situation in the other markets.

Relatively high prices in one auction market cause shippers to send a larger proportion of their shipments to that market. Conversely, relatively low prices in a market result in proportionately smaller shipments to that market. Consequently, the season's average prices in the various markets tend to approximate each other. But this tendency in Bartlettpear prices is not evident if the prices are considered for periods of less than two or three months. Furthermore, differences in costs such as icing charges, and nonhomogeneity of goods in size and quality, tend to disequalize prices in the various markets.

\footnotetext{
${ }^{13}$ Freight rates and refrigeration charges for shipments to each of the auction markets are given in table 24 (p. 314). By using the freight rate of $\$ 1.63$ per 100 pounds and a minimum-weight car of 27,500 pounds, the aggregate carriage cost (freight plus standard refrigeration) as of June 11 , 1940, was $\$ 0.988$ per 50 -pound box to New York, and $\$ 0.959$ to Chicago.
} 
Examination of the season's average prices in the four markets leads to the observation that in all the years from 1920 to 1940, New York prices were either the highest or second highest in the group. In fact, New York prices were the highest of the group in all years except three; in 1922 and 1927 Chicago was highest; and in 1928 the Philadelphia price was higher than that of New York by only 1 cent. No one of the four markets consistently has the lowest season's average price, but in no year of the 1920-1940 period was it characteristic of the New York price to be the lowest.

The differentials between the Chicago annual prices and those of the three eastern auction markets do not consistently reflect the differentials in transport charges. For example, the Chicago price is not less than the New York price by the amount of the transport differential between the two markets. The excess of the New York price over the Chicago price varies from year to year and for two years the New York price was under that of Chicago. It may very well be that the price differentials between the markets in the various seasons may be accounted for largely by different sizes and qualities. Although since 1929 season's average prices in New York have been slightly higher than those in the other major auction markets, New York prices are perhaps more representative of pear prices than prices of other auction markets. This is largely due to the fact that New York is the largest auction market, and pear growers and shippers follow its prices closely.

The interaction between auction markets is related to shipments, car diversions, and telegraphic information sent from one market to another. Shipments are not directed to various auctions, according to some rigid rule, but on the basis of general and special information concerning demand situations, business conditions, and other information that may be available.

\section{WEEKLY AVERAGE PRICES IN MAJOR AUCTION MARKETS}

A number of important characteristics that are obscured in the season's averages become evident and are emphasized in the weekly prices. In the analysis of relations between weekly prices of various markets, eight of the twelve auction markets were considered. The choice of the individual markets was made on two criteria : (1) auction markets that are important on the basis of volume of sales; and (2) auction markets that are located in certain geographical areas. The two groups, four markets in each, were chosen as follows :

$\begin{array}{ll}\text { Group I } & \text { Group II } \\ \text { Boston } & \text { Detroit } \\ \text { New York } & \text { Cleveland } \\ \text { Philadelphia } & \text { Cincinnati } \\ \text { Baltimore } & \text { Pittsburgh }\end{array}$


The markets in group I are all on the Atlantic seaboard and, except Baltimore, are of the larger markets. They are sufficiently close together so that there is no significant difference in carriage charges from California. The markets in group II are considered together since they are
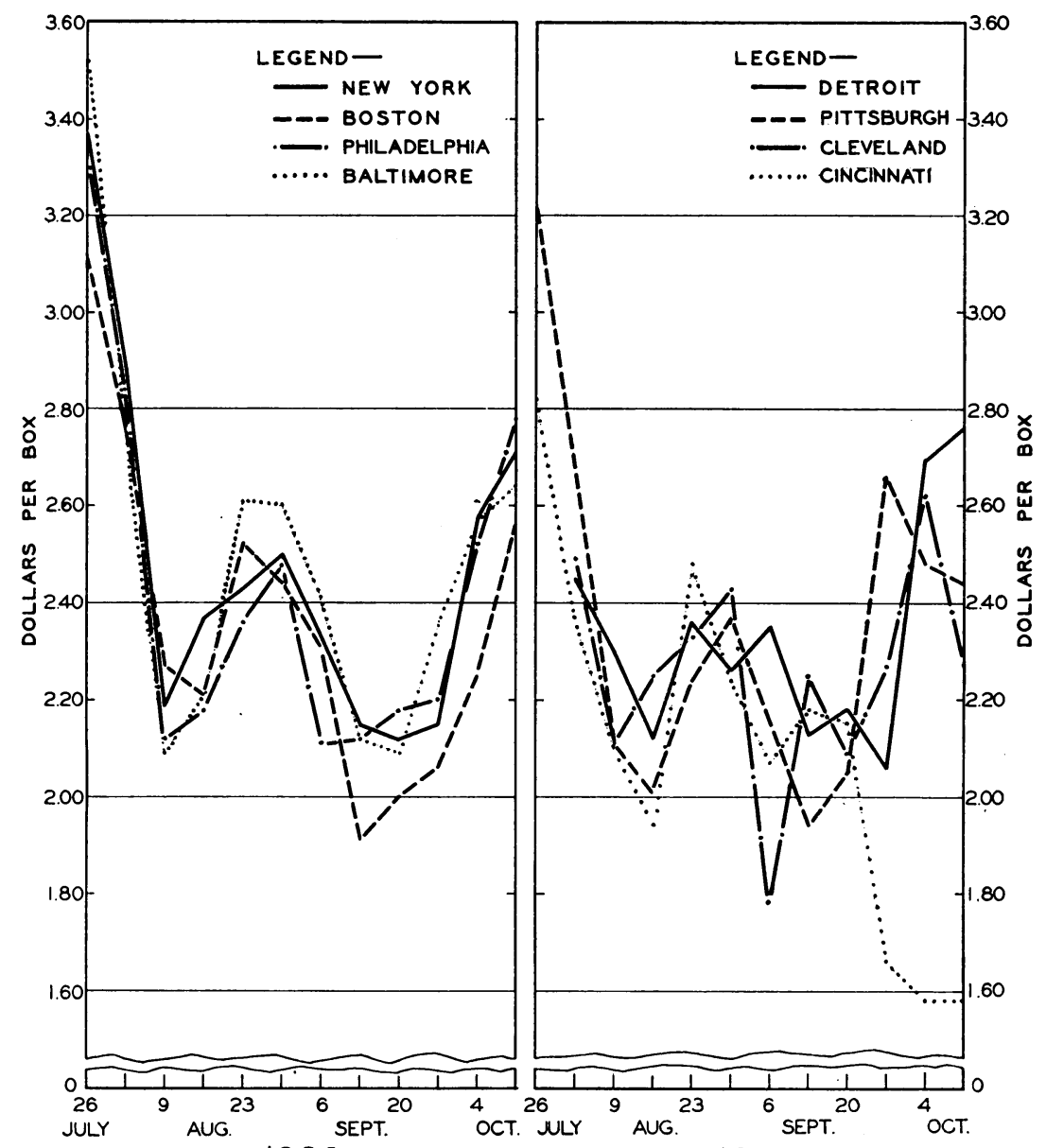

1935

1935

Fig. 6.-Weekly auction prices of California Bartlett pears in eight cities, 1935.

Data from table 22 (p. 311).

of approximately equal importance in sales volume and represent a fairly homogeneous group on the basis of transportation charges that are incurred in marketing California Bartletts. The latter are more comparable to each other in size than are those in group I. The weekly prices in the two groups of markets for 1935-1940, inclusive, are given in table 22 ; the prices for 1935 are shown in figure 6. 
Seasonal Variation in Weekly Prices in Major Auction Markets.-The seasonal patterns of weekly prices in the six years 1935-1940 are broadly similar in each of the eight markets. The weekly price patterns, however, differ more than the season's prices discussed above (p. 255). Only in 1936 were the patterns of seasonal variation in weekly prices relatively close in conformation for both groups of markets. During 1935 the weekly prices of the eastern group of markets followed a broadly similar pattern, but in the more western markets the weekly prices were extremely divergent. Data for 1935-1940 are insufficient evidence from which to generalize that the weekly prices of one group of markets are more divergent than those of the other markets. There are no apparent a priori grounds for expecting eastern weekly prices to follow each other more closely than do those in the western markets. The differentials between weekly prices in the various markets are no doubt due to individual peculiarities in the several markets such as local situations in supply and demand of pears, different levels and distributions of money income, divergent qualities of particular receipts, and different situations in competition from other fruits and foods.

Among several auction markets the weekly prices may closely follow the prevailing price level or at times vary widely between themselves. The price differential from market to market may be only slight or sufficiently wide to indicate that special and unusual circumstances exist in some of the markets. When the price differences are small, they may be due largely to insignificant variations from the prevailing price level. But wide differences between the prices of auction markets cannot be dismissed as insignificant variations. There arises the problem of distinguishing price differences sufficiently wide so that they indicate unusual price relations between the several auction markets.

Clearly, the Bartlett price movement within a single season is dominated by the seasonal variation in price, which is largely due to the seasonal pattern of shipments and sales. There are statistical techniques useful in studying the extent to which prices in several markets, each one characterized by a marked seasonal variation in price, may exhibit chance variations from the prevailing price level. ${ }^{14}$ Such a statistical method, analysis of variance, is here used in studying the pear price relations between the auction markets in group I and in group II.

Analysis of Variance.-During 1936, 1937, and 1938, weekly prices in the two groups of auction markets did not widely differ among themselves, and the price differences may easily have been due to chance variations from the prevailing level of Bartlett prices. During 1935,

\footnotetext{
14 The technique is discussed in: Snedecor, G. W. Calculation and interpretation of analysis of variance and covariance. p. 21-28. Collegiate Press, Inc., Ames, Iowa. 1934.
} 
however, the price behavior in both groups of auction markets was of a different character. In the 1935 California Bartlett-pear season, the differences between auction-market weekly prices were wider and more frequent than in the subsequent three years. The 1935 price differences between Boston, New York, Philadelphia, and Baltimore are barely significant. And in the same season price differences between the markets in group II-Detroit, Cleveland, Cincinnati, and Pittsburgh-were unusually wide and frequent. The latter price differences are sufficiently large so that they cannot be attributed to random variation of the auction-market prices from the prevailing level of Bartlett prices in the markets of group II. ${ }^{15}$

Large Differences between Weekly Prices of Auction Markets.-In examining the unusually wide differentials between the weekly prices of the markets in group II during 1935, the question arises whether an unusually large or an unusually small volume of sales was made in the markets whose prices were out of line with those of the other markets. As shown in figure 6, the price in Cleveland for the week of September 6 in the 1935 season was much below the price in the other markets. But the volume of sales in that week was only about three fourths of the average weekly sales in Cleveland during the season. On the assumption that the volume of sales is highly correlated with the market supplies ${ }^{18}$ there is little evidence that the low price in Cleveland resulted from redundant supplies of Bartletts relative to other weeks in the season. During the week of September 6, 1935, Cleveland sales were 1.7 per cent of the total for the twelve auctions; whereas for the whole season, sales in Cleveland were 2.5 per cent of the total of the auction markets.

In the week ending September 27, 1935, there was a price spread of $\$ 1.00$ a box between Pittsburgh and Cincinnati. The relatively high price in Pittsburgh may be partly accounted for by its extremely small volume of sales during that week, but sales in Cincinnati were also very small. In fact, the Cincinnati price continued much below other market prices during the remaining two weeks of the marketing season. Detailed examination of the weekly data on sales and prices in the individual markets fails to give evidence that the auction-market price differentials are solely or even largely due to relative volumes of sales in the different markets. Extremely wide spreads between the weekly prices of different markets may result from numerous situations peculiar to individual markets. Some such situations may be due to market position of pears

${ }^{15}$ The statistical results upon which these conclusions are based are given in table 23 (p. 313).

${ }^{10}$ In the New York market, auction sales of Bartletts and supplies as measured by unloads of California pears, are highly correlated directly. This relation between auction sales and supplies in New York is the basis for the assumption that a similar relation is characteristic of the other markets. 
other than California Bartletts; to the supplies and prices of other fruits; to the quality and size of Bartletts sold in the various markets. For many of these factors, such as the quality and sizes of weekly supplies in the individual auction markets, and the statistical position of competing fruits which may vary from market to market, adequate quantitative information is not available. Thus, the price differentials between auction markets can be explained only in general terms.

Factors Determining Prices in Various Auction Markets.-The factors primarily determining the prices in the various auction markets may be classified into two broad eategories. First, there are those forces that are common to, and operate in, all of the markets. Such general influences dominate the wider price swings, especially those that occur over a period of several weeks or months. The pattern of seasonal variation in shipments and sales may be classified as such a broad general price influence. Forces in this category tend to maintain prices in a single market within certain limits of the prices in other markets, or what is usually referred to as "keeping the prices in line."

Second, there are those forces that are peculiar to individual markets. Such influences affect the daily and weekly price variations in single markets. The quality and sizes of shipments received in a market, the level of consumers' purchasing power relative to that in other markets, and the relative importance of other fruits are several of the many price influences that may be peculiar to a single market. Forces in this second eategory not only tend to cause price discrepancies between the various markets, but also prevent a prompt adjustment of such discrepancies.

The interaction of the two sets of price influences results in the intermarket price relations. Since season's average prices of the separate markets are primarily determined by influences common to all markets, they closely approximate each other. Daily and weekly prices in one market, however, often differ widely from corresponding prices in other markets because, over short intervals of time, such as several days or a week, the influences peculiar to a single market superimpose their price effects upon, and may even dominate, the price influences common to all markets. Consequently, within a single season there may be substantial price differences between several markets; but over the season as a whole the general price behavior in the several markets is similar and their season's average prices are close to each other.

In analyzing weekly price variability, variation within the two groups of markets has been considered. The analysis indicates that the broader price movements within the season are common to all auction markets, but over a period of several weeks prices in several markets may diverge widely. This was particularly true for the four western markets (group 
II) during the 1935 season. Individual markets may reach their midseason lows and peaks of prices in different weeks. Examination of price relations between various markets does not indicate that any particular market is dominant in price leadership ; price movements in any particular market do not tend to follow the price movement initiated in some other market. The similarity of price movement common to all markets is not due to the influences operating in a single market, but is largely due to influences acting on all markets simultaneously. The fact that Bartletts are perishable and may not be easily arbitraged between markets as are many staple commodities, results in a certain degree of independence between the various pear markets. But a certain amount of diversion of cars is feasible. Fruit rolling east that was originally intended for New York may, on passing through Chicago, be diverted to Boston or Philadelphia. Pears once in New York are not likely to be shipped back to Chicago or St. Louis, but it is not unusual for an excess of cars on track in New York to be diverted to Philadelphia. Unquestionably, however, Bartletts are not diverted from one market to another to the same extent as less perishable agricultural commodities.

\section{POLICIES OF DISTRIBUTING SHIPMENTS AMONG VARIOUS MARKETS}

The price relations between auction markets are of considerable importance to growers, shippers, and sales organizations. The wide differences between auction-market prices frequently have been related, according to trade comments, to unsatisfactory distribution of shipments to the various markets. Trade papers frequently suggest that market gluts and associated relatively low prices are the results of overshipments to certain markets. These opinions have become so strongly entrenched that attempts have been made to distribute shipments "more evenly" between auction markets during the 1939 and 1940 seasons.

Marketing Policy of the Control Committee of the Deciduous Tree Fruit Marketing Agreement.-During the latter part of 1939 season and all of the 1940 season, the Control Committee of the Deciduous Tree Fruit Marketing Agreement operated on the premise that within a single season the weekly price differentials between markets are due largely to the manner in which pear shipments are distributed. Therefore, by the appropriate distribution of shipments between various markets the price differences could be influenced in such a manner that total net returns to growers would be increased. Shipment distribution was influenced by the following method. The Control Committee of the Deciduous Tree Fruit Marketing Agreement maintained a voluntary clearinghouse whose function was to gather pertinent current information on the 
flow of shipments and the supply and demand situation in the various markets. ${ }^{17}$ Each day the Control Committee issued a summary of the shipments and diversions to, and receipts in, the auction markets. Information on the volume of supplies due to arrive in the individual markets was also made available to shippers. ${ }^{18}$ Shippers having access to such information are in a more favorable position to direct and divert their shipments to those markets which they believe would yield the highest monetary returns. The supposed net effect or the purpose of such a program is to equalize, to a greater extent than previously, the prices in the different markets. In other words, the Control Committee attempted to approximate the same results that would be secured under a system of perfect competition.

The Control Committee did not set up a pooling system that would involve "the physical mingling of the products, the combining of sales returns, the merging of operating expenses, and the division of the net returns among the several members."18 On the contrary, each shipper was free to send his pears to whichever market he chose, and the sales returns went directly to him. Consequently, the Control Committee was not able to distribute shipments between markets so that aggregate returns to all growers would be maximized. Therefore, the Committee was not in a position to follow a policy of price discrimination between geographically different markets. Moreover, conditions other than supply control are necessary to make such a marketing policy feasible.

An Alternative Policy of Distribution of Shipments among Various Markets.-Very likely, the intermarket price differentials are partly due to the manner in which pear shipments are distributed between markets. Changes in the distribution of shipments may be expected to result in changes in the price relations between the auction markets. Under certain conditions, pear shipments may be distributed so that the prices in various markets will come closer together than they do under present methods of distribution. Such a goal in the distribution of shipments may be extremely difficult to attain, and especially to maintain. An alternative is to distribute shipments among auction markets so that their price differences will result in maximum returns to the group effecting the distribution.

\footnotetext{
${ }^{17}$ Shippers were not obligated to give the Control Committee information on their shipments. All such information was given voluntarily, except data on daily total pack-out, which were required under the marketing agreement. The voluntary clearinghouse was largely a means of pooling and disseminating information of interest to shippers.

${ }^{18}$ Information on eastern auction markets was first made available near the close of the 1939 shipping season. It was continued during the 1940 season.

${ }^{10}$ Wellman, H. R., and M. D. Street. Maintenance of substantial equity in the pooling of lemons. California Agr. Exp. Sta. Bul. 619:1. 1938. This study concerns itself with many problems involved in the operation of pooling systems.
} 
Under the assumption that growers as a group are interested in obtaining the largest returns possible from their pears shipped to the various markets, what conditions are necessary to obtain this ideal objective? First, all shippers must pool their shipments so that there will be a single control of supplies flowing to consuming centers. Under certain conditions, an industry having control over its supply may so regulate its distribution of output among several markets that its total net returns from all the markets will be a maximum. ${ }^{20}$

Are the two conditions of market independence and different elasticities of demands ${ }^{21}$ in the various markets fulfilled by the major fruit auctions? There are grounds for believing that the pear auction markets cannot be divided so that they will be independent of each other. With price differences sufficiently wide to counterbalance transference charges, it is not only possible but logical for regular purchasers in one market to purchase their supplies in another market. If the Philadelphia price were sufficiently above the New York price, regular purchasers in Philadelphia would purchase their supplies in New York. This is what actually occurs at present, and is one of the elements that tends to keep in line the prices in the various markets. There is little doubt that the fruit auction markets are interdependent and cannot be divided at will. True, the Chicago and New York markets are less interdependent than are Philadelphia and Baltimore. Those who usually purchase their Cali-

${ }^{20}$ According to Mrs. Robinson (Robinson, Joan. The economies of imperfect competition. p. 179-202. The Macmillan Company, London. 1934.), the conditions are: (1) the markets are independent so that goods sold in one of the markets cannot be purchased there and resold in another market, and purchasers cannot shift from one market to another; (2) there is a difference between the elasticities of demands in the various markets in which the shipping organization sells its goods. If these two conditions are fulfilled, an organization that can control its output may regulate its sales in the various markets so that the marginal revenue received from selling an additional unit in any one of the markets is the same for all the markets in which it sells. When the marginal revenue in each market is equal to both the marginal cost and the marginal revenue of the entire output, the aggregate net returns will be at a maximum.

For total returns to be maximized rather than minimized, by equating marginal revenues in the various markets, the total-returns curves must meet certain conditions not adequately dealt with by Mrs. Robinson. Using for simplicity only two markets, the conditions may be indicated as follows: If both of the total-returns curves are concave from above, equating marginal revenues maximizes total returns. If both total-returns curves are convex, equating marginal revenues minimizes total returns. If the total-returns curve of one market is concave and that of the other market is convex, the result depends on which has the greater curvature. The curvature at any point may be mathematically expressed by the second derivative of the curve at that point. If the algebraic sum of the second derivatives of the two curves is positive, equating marginal revenues maximizes total returns. But if the sum of the second derivatives is negative, equating marginal revenues minimizes total returns from the two markets. For a detailed discussion of this and related problems see: Waugh, F. V., E. L. Burtis, and A. F. Wolf. The controlled distribution of a crop among independent markets. Quar. Jour. Econ. 51(1):1-41. November, 1936.

"1 Elasticity of demand expresses a relation between changes in volume sold and changes in price; it is defined, at any price or volume of sales, as the proportional change of amount purchased in response to a small change in price, divided by the proportional change of price. 
fornia Bartletts on the Chicago market cannot shift to the New York auction as easily as a Baltimore purchaser can shift to Philadelphia. To this extent some degree of independence exists between the major fruit auction markets. But an element of considerable importance is the nature of perishability of California Bartletts. They cannot be transferred from market to market without unfavorably affecting their quality. Thus, the degree of market interdependence is sufficient so that shipments may not be regulated in one market without consideration to the effect on other markets.

But market independence is only one of the two conditions prerequisite to maximizing net returns by regulating shipments and influencing the market prices. The other condition is that in the separate markets the elasticities of demands are not equal. The functional relation between sales and prices should not be the same in all of the markets. Although the present writers are not in a position to maintain that the elasticity of demand for California Bartletts is substantially different in New York from that in Chicago, Philadelphia, or Boston, it may so be ; only further analysis and study will give reliable indications.

The policy of geographical price discrimination by the Control Committee was not possible for several reasons. First, the Committee did not have the authority to pool shipments and control the flow of pears to individual markets. ${ }^{22}$ Thus, an essential condition of supply control was lacking. Second, the Committee did not have the authority to discriminate among shippers by directing the pears of one shipper to a market where the price is lower than in another market to which, at the same time, the pears of another shipper were sent. Individual shippers could not be expected to accept such a practice unless some equitable method of pooling sales returns were established. Third, a marked degree of geographical price discrimination would be hampered by the existence of fruits competing with California Bartletts in consumption. Relatively high Bartlett prices in some markets may result in consumers' turning to other fruits. Thus, it is fairly clear that geographical price discrimination is not a feasible method, under present trade conditions and at least under the voluntary clearinghouse, to increase growers' returns.

\footnotetext{
${ }^{22}$ In a proposed marketing agreement regulating the shipping of fresh Bartlett pears grown in California, an interesting feature was that a committee would have the authority to regulate the distribution of shipments between markets. (See: Revised preliminary draft of a proposed marketing agreement regulating the shipping of fresh Bartlett pears, plums, peaches, apricots, and cherries grown in the state of California. Draft No. 2, January 3, 1939. Mimeo.) However, in the final agreement, the feature of intermarket regulation of shipments was not included. (See: United States Department of Agriculture Division of Marketing and Marketing Agreements. Marketing agreement regulating the handling of fresh Bartlett pears, plums, and Elberta peaches grown in the state of California. Marketing Agreement Series, Agreement No. 85:1-25. Issued May 24, 1939; effective May 29, 1939.)
} 
One might question why a single shipper may not practice price discrimination in order to maximize his returns. The answer is that although a single shipper may control the distribution of his shipments to various markets, his supplies are such a small proportion of the total market supplies that he alone cannot substantially affect the market price. It is clearly to the advantage of each individual, acting alone, to send his pears to that market which at the time of his goods' arrival has the highest price and thereby receive as large net returns as he possibly can under the conditions. In fact, such a practice is one of the elements that tend to equalize prices in the various markets.

No doubt it is possible to improve the present methods of distributing Bartlett shipments among various markets. Improved channels of market information, more detailed knowledge of supplies and prices of other fruits that may compete with California Bartletts, and more detailed information on special circumstances in some of the markets are only several of many possible means of increasing the effectiveness in distributing Bartletts to the various auctions. Along such lines rather than following some rigid rule, improvements in market allocations are likely to result in increased net returns to growers and shippers. However, the fuller utilization by individual shippers of such information as noted above tends to equalize prices in the various markets, and yields results compatible with conditions approximating unrestricted competition.

\section{RELATIONS BETWEEN PEARS AND OTHER FRESH FRUITS}

In the study and analysis of California Bartlett prices it is at times convenient to disregard the prices of other fresh fruits and their relations to pears. But such a procedure can only be of temporary value, since California Bartlett pears are only one of a large number of fruits that receive consumers' attention in the market. Obviously, complex relations may exist between the various types of fruits and even varieties within one type. Therefore, some attention must be paid to at least several other fruits whose prices may be related to those of California Bartletts.

Bartletts from the Pacific Northwest (Washington and Oregon) are not shipped to the eastern markets until the last four or five weeks of the California shipping season. Consequently, during the first seven or eight weeks of their shipping season, California Bartletts are the only fresh pears available to consumers in substantial quantities. As for other fresh fruits, the situation is even more complicated. Considerable quantities of oranges, peaches, and plums are sold in the auction markets during the major part of the entire California Bartlett season. This consideration has led many connected with the California Bartlett trade to believe that 
their goods suffer heavily from competition with other fresh fruits, especially oranges.

\section{RELATIONS TO OTHER FRESH FRUITS}

Trade journals frequently report that the "pear deal" has turned out unfavorably because fresh peaches or other fruits were abundant and cheap, or consumers are turning to citrus fruits. Not only are such comments numerous in fruit trade publications, but similar opinions are expressed verbally by some individuals in the trade. Examination of the literature on the demand and prices of fresh fruits, however, did not uncover economic and statistical studies giving evidence for concluding that pears do compete with other fresh fruits in consumption. For this reason, it was not only appropriate but also requisite that some attention be given to the relations of pears to the supplies and prices of certain other fruits. ${ }^{23}$ Such information is not only useful but even necessary to evaluate adequately the effects of pear-marketing agreements and programs.

Concept of Related Demands.-Within the past two decades a considerable body of economic literature concerning related demands and competition among commodities has become available. Although such discussions have largely been theoretical and pertain to the principles involved, some of the literature concerns empirical tests of commodity competition, and such tests have been used in the study of relations between a number of agricultural goods. ${ }^{24}$

In the statistical or empirical examination of the related demands of two goods, some objective criterion as a standard, or basis, is necessary. For instance, the term "competition" has already been used without stating in definite terms what is meant. True, the phrase "competing goods" connotes in some manner, even if a vague one, its meaning. It is also true that the words "competing goods" have what may be termed a "commonsense" connotation. But a disadvantage of not explicitly defining the conditions when goods may be considered as competing is that different individuals, or even the same individual at different times, may interpret the phrase in various senses.

Thus, in discussing the concept of related goods, it is useful for purposes of exposition to begin with two limiting cases : perfectly completing goods and perfectly competing goods. Two commodities may be defined as perfectly completing if they can be used only jointly and in a fixed ratio; they cannot be used separately. For example, a glove for

\footnotetext{
${ }^{23}$ For a critical summary discussion see: Hoos, Sidney. An investigation on complementarity relations between fresh fruits. Jour. Farm Econ. 23(2):421-33. May, 1941.

${ }_{24}$ Schultz, Henry. The theory and measurement of demand. p. 569-654. University of Chicago Press, Chicago. 1938.
} 
the left hand and a glove for the right hand are perfectly completing for most people. Two commodities may be defined as perfectly competing if they can be substituted for each other in a constant ratio; one commodity may be substituted for the other, and each one can be used separately. Thus, assuming no difference in flavor, texture, color, and nutritive value, ketchup made from Maryland tomatoes and ketchup made from New Jersey tomatoes may be used as an example of perfectly competing goods.

Actually, however, very few, if any, pairs of commodities are perfectly competing or perfectly completing in consumption. But the implications that these two limiting cases lead to may serve as a basis for an empirical test of intermediate cases which are the most numerous and important in experience. The quantity and price data of perfectly competing and perfectly completing commodities would fulfill certain conditions. By using these conditions as criteria, an empirical test is suggested for ascertaining whether two commodities are competing or completing in consumption.

The conditions and test may be explained in the following terms : By definition, perfectly completing goods are consumed in a constant ratio to one another regardless of their relative prices. These conditions imply that for two completing commodities, even if they are not perfectly completing, their ratio of quantities consumed varies relatively less than their corresponding price ratios. By statistically measuring and comparing the relative fluctuations of the quantity ratios and price ratios, one has an objective basis for determining whether the two commodities are completing. Similar reasoning may be followed in testing whether two goods are competing in consumption. If two goods are perfect substitutes for each other, their prices must be in a constant ratio. Only one of the goods will be bought and consumed if their price ratio is different from that at which the two goods will be substituted for each other. By the definition of competing goods, their price ratio must be constant and equal to the same ratio in which one good can be substituted for the other. But regardless of their constant price ratio, the ratio in which the two goods are consumed is not restricted, and a relatively large change in the quantity ratio will result from a small change in the price ratio. The implication follows that for two competing goods, even if they are not perfectly competing, their price ratio varies relatively less than their quantity ratio. Thus by statistically measuring the relative variations in the ratios of prices and quantities, one may empirically determine whether two goods are competing in consumption.

To illustrate further, in investigating the related demands between pears and another fresh fruit, plums, data on supplies and prices are used over a sixteen-year period, 1924-1939. Over such a period two goods 
may be competing in one part of the period and noncompeting in another part. Furthermore, the two goods may be competing within one range of prices and noncompeting in another range. But in considering the period as a whole, the statistical results do not apply to individual years, or indicate to what extent the relations between the commodities are changing over time. The results are indicative of average relations over the sixteenyear interval, though study of agricultural commodities familiarizes one with the fact that to some extent each season has its individual characteristics and is a new experiment.

As noted above, quantity and price data are utilized in empirically determining the related demands of pairs of goods. But consideration must be given to the time units of the data. For example, in studying the relation between Bartlett pears and oranges during November, the results probably would be different from those for the period from July to September. In the July-September period, there is heavy marketing of pears and very small marketing in November, whereas the marketing of oranges during the two periods has less of a seasonal variation. Furthermore, the relations between pairs of goods may change over time. Changes in consumer choices and food habits, and technological and sociological developments are reflected in variations in the relations between many commodities. Hence, the correlated demands of various commodities should not be considered any more permanent than the state of technological development, consumers' wants and opinions, and the level of economic development.

\section{RELATIONS OF THREE OTHER FRESH FRUITS TO PEARS}

Three other fresh fruits-peaches, plums, and oranges-have been selected to compare their relations with pears. The price data of the four fruits are averages for sales in New York for the two-month period of July and August. The quantity data refer to unloads in New York during the same two-month interval. The period July and August was chosen because heavy marketings of pears, peaches, plums, and summer oranges take place during those months. The pear, peach, and plum seasons do not entirely coincide; thus it is necessary to study the intercommodity relations during a period when relatively heavy unloads are made in all the fruits considered; July-August is such a period.

Trends in Unloads and Prices.-As shown in figure 7, from 1924 to 1939 the tonnage of July-August orange unloads in New York fluctuated about a strongly rising trend. The large increase is a rough index of the growth in the consumption of citrus fruits. Average annual JulyAugust unloads for 1934-1939 were about 60 per cent larger than those during 1929-1933; but during 1934-1939, orange unloads averaged only 
slightly higher than the immediately preceding years. From 1924 to 1931 peach unloads during July-August fluctuated widely about the level of 40,000 tons, with 30,000 tons in 1930 and 50,000 tons in 1931 as the extreme variations. Since 1932 the volume of peach unloads has fluctuated
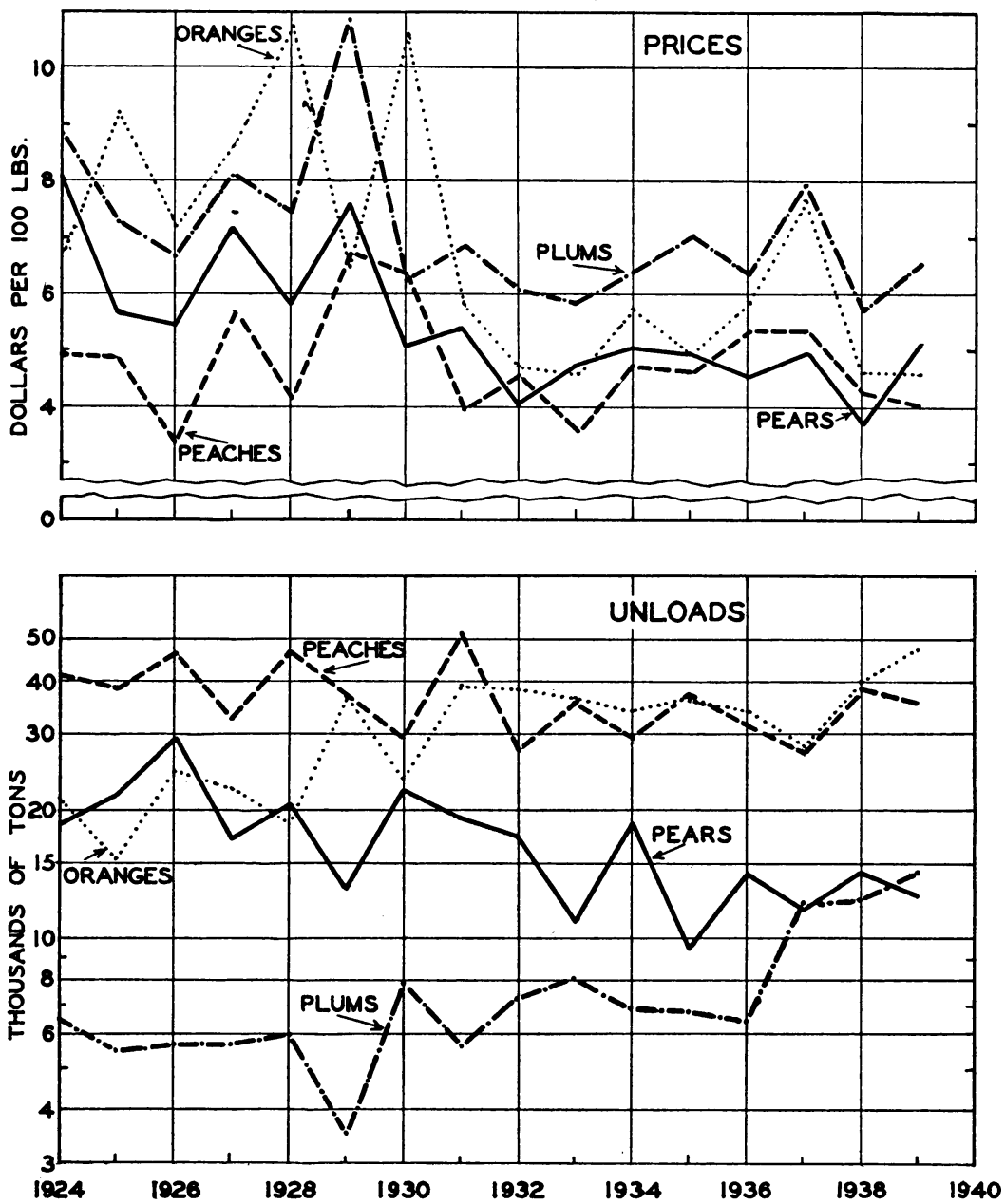

Fig. 7.-New York wholesale prices and unloads of pears, plums, peaches, and oranges, July-August, 1924-1939.

Data from tables 25 and 26 (p. 315 and 316).

relatively less widely and followed a lower horizontal trend. Over the 1924-1939 period as a whole, peach unloads have followed a slightly declining secular trend. Since 1935 the July-August unloads of oranges and peaches have been about equal when measured in number of tons. 
Unloads of plums followed an upward trend from 1924 to 1933, declined during the next three years, but in 1937 and 1938 were double the 1924 1928 average with unloads of about 12,000 tons. The secular trend in unloads of plums has been markedly upward.

Although California Bartlett unloads for July and August have varied greatly from year to year during 1924-1939, the secular trend has been definitely downward. Such a trend is particularly evident when contrasted with the rising trend in the unloads of plums and oranges. Figure 7 shows that average unloads of pears and oranges were about the same during 1924-1928, but by 1935-1939 unloads of oranges had increased until they were over two and a half times the unloads of pears during the same period. Unloads of pears, which were about four times the volume of plum unloads during 1924-1928, declined to about one and a half times the plum unloads for the period 1935-1939, and during 1938-1939 were about equal to plum unloads. These broad comparisons indicate that per-capita consumpion of pears in July and August, at least in New York, declined not only absolutely but also in relation to plums, peaches, and oranges during the sixteen-year period from 1924 to 1939.

The prices of the four fruits-pears, peaches, plums, and orangesshown in the upper deck of figure 7, are expressed in terms of dollars per 100 pounds in order to compare the prices relative to a common base. $\mathrm{A}$ shortcoming of the procedure used here is that 100 pounds of one fruit, oranges for example, may have a different nutritive value than 100 pounds of pears. One method of overcoming this disadvantage is to express the prices of the various fruits in terms of a measure of nutrition, such as a certain number of monetary units per 1,000 calories. But from a dietetic and even an economic basis, nutritive value is not the only consideration in price comparisons ; consumers' preferences and tastes, regardless of relative nutritive values, also are important elements. For these reasons the conventional method of expressing the prices in terms of a common unit of weight has been followed.

The upper deck of figure 7 shows the July-August prices of the four fruits at New York from 1924 to 1939. No two of the price series are perfectly correlated, but certain characteristics are common to all of them. In general, the four price series followed a rising trend to 1929, and after 1930 were at a lower level. Over the sixteen-year period, the pattern of California Bartlett prices followed the pattern of plum prices more closely than that of the other two fruits. The year-to-year changes in the prices of pears and plums parallel each other very closely during most of the period. This price relation indicates that probably pears and plums are competing in consumption. 
$\Lambda \mathrm{n}$ important feature emphasized by figure 7 is the relative position of pear prices in comparison with the prices of the other three fresh fruits. Pear prices reached their depression low point in 1932, and since then have recovered relatively less than the prices of the other fruits. Prices of peaches, oranges, and plums were at their depression low points in 1933, and by 1937 had recovered considerably. Plum prices appear to have suffered the least from the impact of the 1930-1935 depression. The failure of a more marked recovery in pear prices since 1932 is important because unloads and sales have generally been decreasing from 1926; consequently, gross returns to growers and shippers have declined. Thus, the question arises whether the decreased sales and low prices of California Bartletts may have been due directly to competition from other fruits. In attempting to answer this question, it is necessary first to obtain objective evidence whether pears do compete in consumption with plums, peaches, and oranges.

\section{STATISTICAL TESTS TO DETERMINE DEMAND RELATIONS BETWEEN PEARS AND THREE OTHER FRUITS}

In order to determine the relations in consumption between pears and the three other fruits, certain statistical tests were used..$^{25}$ The results of the tests apply to large groups of people and not to particular individuals. According to certain criteria of competing and completing goods, it may be shown that two goods, for example butter and margarine, are competing in consumption. Such a result is an average relation and probably does not pertain to some individuals who might not consider buying and consuming one of the goods under any conditions. Some individuals may dislike or be allergic to a certain food, in which special case that food does not compete with other commodities in the consumption of that particular individual. But that is an unusual situation which may not be characteristic of large groups of people. One must bear in mind the distinction between characteristics of individuals and characteristics of groups of individuals. It is the latter which are of interest here from the standpoint of relations between pears and other fruits.

Before applying statistical tests ${ }^{20}$ to determine the relations between California Bartletts and certain other fresh fruits, it is important to emphasize that the results obtained by any statistical test are not decisive.

\footnotetext{
${ }^{25}$ For a discussion of the use and interpretation of the statistieal tests of related demands sec: Hoos, Sidney. An investigation on complementarity relations between fresh fruits. Jour. Farm Econ. 23(2):421-33. May, 1941.

Kozlik, Adolph. An investigation on complimentarity relations between fresh fruits: A reply. Jour. Farm Econ. 23(2):654-56. August, 1941. This second article discusses the inadequacy of the type of analysis given below under test 1.

${ }^{28}$ In the text discussion, two tests and their results are noted. In Appendixes $A$ and $B$ these tests are discussed in further detail, and two additional tests are cxamined.
} 
The most one should expect from such tests is empirical evidence that must be judged on the basis of experience, knowledge of the commodities concerned, and other pertinent information. Regardless of the shortcomings of such tests, however, they are helpful in studying and analyzing the relations between various commodities.

Test 1.-The first test of related demands compares the relative variation in the price ratios and quantity ratios of two fruits. The reasoning behind this test is outlined above (p. 267). Coefficients of variation are used in determining the relative variation in the price ratios and quantity ratios. The results of this test are given in table 6 . These results indicate

TABLE 6

Variation in Price and Quantity Ratios of Pairs of Fruits

\begin{tabular}{|c|c|c|c|}
\hline \multirow{2}{*}{ Commodities } & \multicolumn{2}{|c|}{$\begin{array}{l}\text { Coefficients of variation* } \\
\text { and their standard errors }\end{array}$} & \multirow{2}{*}{$\begin{array}{l}\text { Apparent type } \\
\text { of relation }\end{array}$} \\
\hline & Price ratios & Quantity ratios & \\
\hline 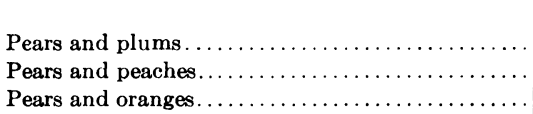 & $\begin{array}{c}\text { per cent } \\
7.3 \pm 1.3 \\
17.0 \pm 3.2 \\
27.1 \pm 5.3\end{array}$ & $\begin{array}{c}\text { per cent } \\
28.7 \pm 5.6 \\
26.0 \pm 5.0 \\
32.6 \pm 6.6\end{array}$ & $\begin{array}{l}\text { Competing } \\
\text { Competing } \\
\text { Noncompeting? }\end{array}$ \\
\hline
\end{tabular}

* Before computing the coefficients of variation, the quantity ratios and price ratios were adjusted for trends, the equations of which are given in Appendix A (p. 292).

Source of data:

Based on data in tables 25 and 26 (p. 315 and 316 ).

some important and interesting relations between California Bartlett pears and the other three fruits. If the presumption is that the degree of competition varies directly with the extent to which the variation in the quantity ratios is greater than the variation in the price ratios, then pears compete more strongly with plums than with peaches. Pears and peaches do compete in consumption according to the above test, but to a lesser degree than might be inferred from statements made by numerous individuals connected with the fruit trade. Moreover, the opinion that pears suffer most from competition with peaches is not supported by the above analysis.

The relation between pears and oranges is ambiguous, at least on the basis of the preceding test. The coefficient of variation of the quantity ratios is larger than the coefficient of variation of the price ratios, and this relation suggests that pears and oranges are competing in consumption. But the difference between the two coefficients of variation appears not to be sufficiently large to be statistically significant. The probability that the difference between the two coefficients may have been due solely to chance may be sufficiently large so that it is doubtful whether the two 
goods are competing. ${ }^{27}$ Although the above test does not give a criterion for independent goods, the presumption is that when the difference between the two coefficients is not statistically significant the two goods may be regarded as independent. Such reasoning suggests that pears and oranges may be independent in consumption rather than directly competitive, although such a conclusion is not in accordance with the opinions of many in the pear trade.

\section{TABLE 7}

Theoretical and Observed Conditions on the Demand Functions as Calculated from the Arithmetic Demand Equations for Pears, Plums, Peaches, and Oranges in New York City, Jult-August, 1924-1938*

(Figures in parentheses are standard errors)

\begin{tabular}{|c|c|c|c|}
\hline \multirow[b]{2}{*}{ Commodities } & \multicolumn{2}{|c|}{ Hotelling condition $\nmid$} & \multirow{2}{*}{$\begin{array}{l}\text { Probable } \\
\text { type of } \\
\text { relation }\end{array}$} \\
\hline & $\frac{\partial y_{i} \ddagger}{\partial x_{j}}=$ & $=\frac{\partial y_{j} \ddagger}{\partial x_{i}}$ & \\
\hline Pears and plums...... & $\begin{array}{c}-0.00657 \\
(0.00928)\end{array} \approx$ & $\begin{array}{r}=-0.01976 \\
(0.00530)\end{array}$ & Competing \\
\hline 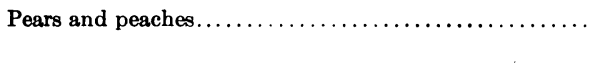 & $\underset{(0.00255)}{-0.00021}=$ & $\begin{array}{r}=-0.00699 \\
(0.00388)\end{array}$ & Competing \\
\hline Pears and oranges........... & $\begin{array}{c}+0.00293 \\
(0.00307)\end{array}$ & $\begin{array}{r}+0.00551 \\
(0.00686)\end{array}$ & Completing \\
\hline
\end{tabular}

* The observed conditions are taken from the multiple-regression equations given in Appendix B (p. 294). In mathematical terms, the Hotelling condition may be expressed as follows: The partial derivative of the price of $A$ with respect to the quantity of $B$ equals the partial derivative of the price of $B$ with respect to the quantity of $\mathrm{A}$; or $\frac{\partial y_{a}}{\partial x_{b}}=\frac{\partial y_{b}}{\partial x_{a}}$. An alternative expression of $\frac{\partial x_{a}}{\partial y_{b}}=\frac{\partial x_{b}}{\partial y_{a}}$.

$\ddagger x_{i}, x_{j}=$ quantities demanded of any two commodities, unloads in 100 tons. $y_{i}, y_{j}=$ the corresponding prices, dollars per 100 pounds.

Test 2.- The second test of related demands is more directly related to the theory of demand. The statistical results are shown here together with a brief discussion of the test to which Schultz refers as the "Hotelling condition" of "the special theory of related demands."28 Table 7 shows the results of test 2 (for further detail see Appendix B, p. 293-96). According to the Hotelling condition, if two goods, A and B, are related in consumption and consumers act rationally, the change in the price of A brought about by a change in the quantity of $B$ equals the change in

\footnotetext{
27 The conventional interpretation of standard errors computed from time-series data cannot be relied upon, since the necessary sampling conditions are not fulfilled by time-series data used here. But the difference between the coefficients of variation of pears and oranges is so small in comparison with the coefficients themselves that it is highly suggestive that the difference is statistically insignificant. In contrast, the differences between the coefficients of variation of the other two pairs of fruits are sufficiently large in relation to the coefficients themselves that it appears highly probable that pears compete with plums and peaches in consumption.

${ }^{28}$ Schultz, Henry. The theory and measurement of demand. p. 569-604. University of Chicago Press, Chicago. 1938.
} 
the price of $B$ brought about by a change in the quantity of $A$. If the two goods are competing, the quantities change in the opposite direction of the prices of the related goods; and if the goods are completing, the quantities change in the same direction as the prices of the related goods.

Examination of table 7 indicates that for two pairs of goods-pears and plums, and pears and peaches_-both terms of the Hotelling-condition equation are negative; whereas for pears and oranges both terms of the equation are positive. Since the signs are alike in both terms of each of the equations, the Hotelling condition is verified qualitatively. The test suggests that pears are competing with both plums and peaches, but completing with oranges. These conclusions follow if the signs of the terms in the Hotelling-condition equations are viewed as the criterion of classification as competing or completing goods. ${ }^{29}$

When one recalls that competing goods may be substituted for each other, the empirical results of tests 1 and 2 appear logical. Pears, peaches, and plums are deciduous fruits that may be eaten fresh or preserved. But oranges, a citrus fruit, are usually purchased and utilized to meet a want different from that which pears usually satisfy. A large proportion of the oranges purchased are consumed in the form of juice. ${ }^{30}$ To that extent pears and oranges are not highly substituted for each other in consumption. Consequently, the results of the two tests agree with what one might expect from the nature of the commodities and their conventional use. Furthermore, the results agree with the opinions of a number of fruit retailers questioned by one of the writers.

\section{RELATED DEMANDS AND FORMULATING MARKETING POLICIES}

The apparent fact that pears compete with plums and peaches in consumption may be of considerable importance in the formulation of marketing and price policies by grower and shipping interests and other groups in the pear trade. If pears compete in consumption with plums and peaches, there are grounds for expecting that when large supplies of plums or peaches are on the market so that their prices are depressed, the price of pears will also decline, since consumers may substitute plums or peaches for pears. But relatively short supplies of plums or peaches are likely to be associated with increased prices of the two fruits, and

\footnotetext{
${ }_{20}$ The criterion that both terms of the Hotelling-condition equation have the same signs is more liberal than the dual requirement that in addition to having the same signs, the two terms must be equal, or at least approximately so. Even with this liberal criterion, the conclusions regarding pears and the other three fruits may be statistically invalid since in each of the equations at least one term is smaller than its standard error.

30 'The extent to which oranges are consumed in the form of juice is indicated by an estimate of the California Fruit Growers Exchange in 1937 that approximately two thirds of the annual orange crop is consumed in the form of juice. (California Fruit Growers Exchange, Annual Report 1937:24. 1937.)
} 
consumers may substitute pears for plums or peaches. Consequently, the market demand for pears may increase and result in an increased price for pears. On the grounds that pears and oranges do not compete in consumption, which the preceding analyses indicate, large supplies and low prices of oranges do not directly adversely affect the prices of pears. The existence of related or correlated demands between various commodities may considerably affect the outcome of a marketing agreement pertaining to only one of the commodities.

Since 1933 various forms of marketing agreements on California Bartletts, under state or federal jurisdiction, or both, have been in effect. Some of those agreements contain features designed to enhance growers' returns by regulating the flow of shipments and raising the market prices. But under certain conditions the net effect of such agreements may be undesirable from the viewpoint of pear growers. $\Lambda$ price-raising, pear-marketing policy, formulated without reference to the correlated demands between pears and peaches or pears and plums, may result in consumers' substituting plums and peaches for pears to such an extent that the returns to growers may actually be reduced. $\Lambda$ brief for or against marketing agreements is not presented here, since their feasibility and success depend on many additional considerations other than related demands. But it is suggested that in the discussion, formulation, and prosecution of marketing programs, consideration be given to the relations between various commodities.

Although the relations of pears to only three fruits-plums, peaches, and oranges-have been considered, it should not be inferred that pears are not related in consumption with other fruits. In fact, it is likely that each fruit (even each food product) is surrounded by a number of related commodities, some competing, others completing, and still others that are independent in consumption. An adequate examination of the interrelations between the many different fruits is a subject that will require much additional theoretical and empirical investigation. This section of the present study must be viewed only as a modest beginning in that direction.

\section{ANALYSIS OF SEASON'S AVERAGE PRICES}

This section is concerned with isolating and measuring the influences that have largely accounted for the year-to-year fluctuations in the season's average prices of California Bartletts. An attempt is made to answer the question: What have been the chief factors that have determined the season's average prices of California fresh Bartletts in eastern auction markets during the 1925-1940 period, and what have been the separate or partial influences of those factors? 
The following analysis indicates that the major influences which have, on the average, primarily determined the season's weighted-average delivered-auction price of California fresh Bartletts in the seven chief markets during the 1925-1940 period were as follows: (1) volume of interstate shipments of all California pears during the California Bartlett shipping season, (2) volume of Oregon and Washington shipments of pears during the California Bartlett shipping season, (3) the level of United States nonagricultural income payments for July through October, and (4) a "time" trend which represents those factors that have

TABLE 8

United States Annual Per-Capita Consumption of Pears, 1924-1938

\begin{tabular}{|c|c|c|c|}
\hline Use & $1924-1928$ & $1929-1933$ & $1934-1938$ \\
\hline 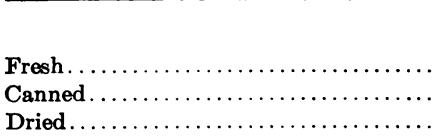 & $\begin{array}{c}\text { pounds, fresh } \\
\text { equivalent } \\
6.6 \\
0.7 \\
0.1\end{array}$ & $\begin{array}{c}\text { pounds, fresh } \\
\text { equivalent } \\
6.0 \\
1.0 \\
0.1\end{array}$ & $\begin{array}{c}\text { pounds, fresh } \\
\text { equivalent } \\
7.1 \\
1.3 \\
0.1\end{array}$ \\
\hline Total $\ldots \ldots \ldots \ldots \ldots \ldots \ldots \ldots \ldots \ldots \ldots$ & 7.4 & 7.1 & 8.5 \\
\hline
\end{tabular}

Source of data:

From: Shear, S. W. Deciduous fruitstatistics as of January, 1941, Univ. of California Giannini Foundation Mimeo. Rept. 76:4-6. 1941.

linearly and smoothly changed through time. Influences other than the four listed above, however, have been instrumental in determining Bartlett pear prices. For some of those influences, such as quality, quantitative measures are not available; for others, such as varying proportions of different sizes in various seasons, data are inadequate. Although such price determinants are of marked interest, in the aggregate their price effects are less than the four major influences listed above. The relations between California Bartletts and certain other fresh fruits have been examined in the preceding section, "Relations between Pears and Other Fresh Fruits." Since a complete statistical explanation of the variation in Bartlett prices is impossible here, the present authors endeavor to present an analysis which will be of considerable aid in understanding the price behavior of, and in formulating marketing policies for, California fresh Bartletts.

\section{TRENDS IN SUPPLIES AND PRICES OF PEARS}

As a background for the subsequent discussion, trends in supplies and prices of several components of United States fresh pears are noted. Table 8 shows United States annual per-capita consumption of pears by five-year periods. From 1924-1928 to 1934-1938 per-capita consumption of pears, all forms in fresh equivalent, increased about 15 per cent, or 
1.1 pounds. Of the increase, 45 per cent occurred in fresh pears, and 55 per cent in canned pears including those used in canned fruit salad and cocktail. Since interstate shipments and sales of California fresh Bartletts declined, the inference is that their per-capita consumption has
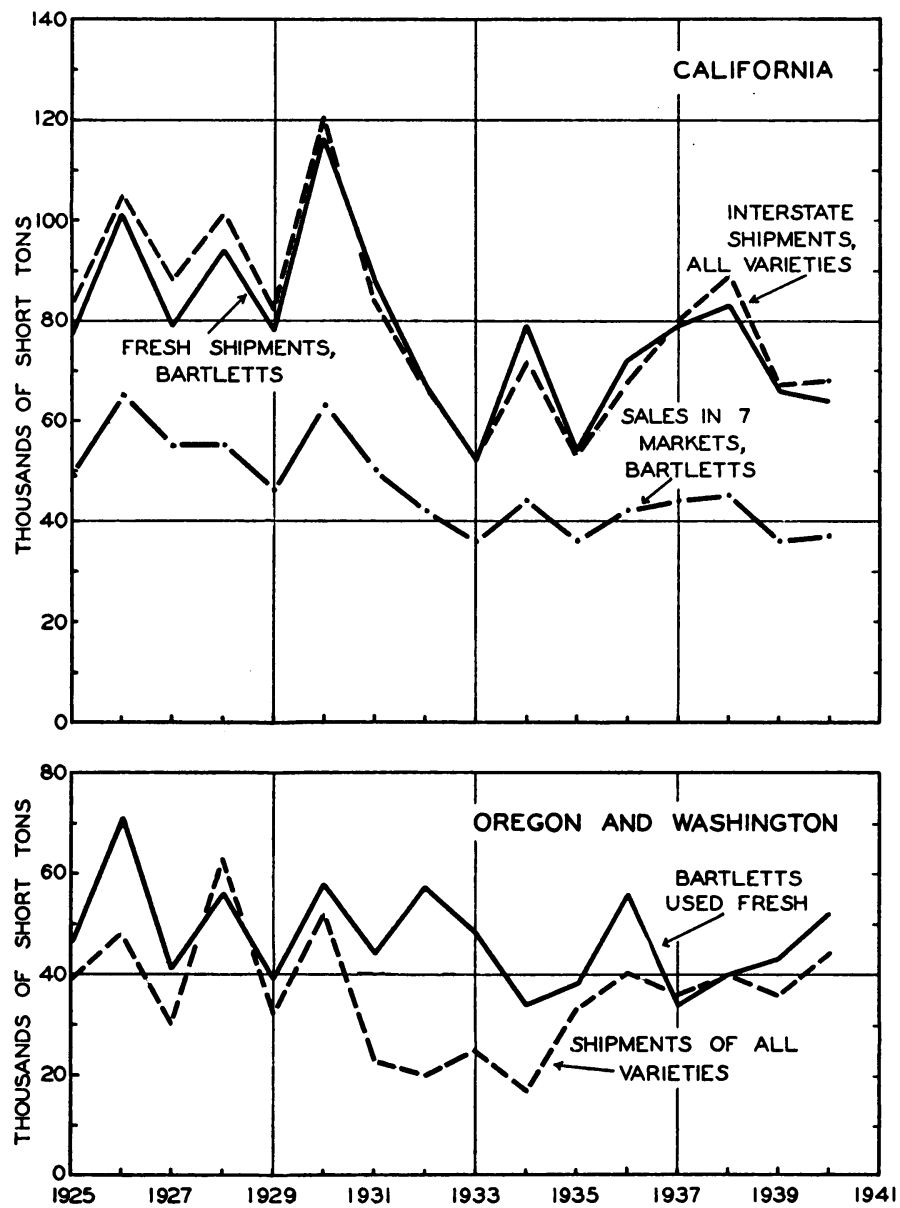

Fig. 8.-Supplies of California and Oregon and Washington fresh Bartlett pears, 1925-1940.

Data from table 27 (p. 317).

decreased. But part of the increase in canned pears came from increased use of California Bartletts for canning. The presumption is that the consumption of fresh California Bartletts is decreasing while their utilization for canning is increasing; and canning of California Bartletts is becoming relatively more important than fresh shipments. 
Supplies of Pacific Coast Pears.-Figure 8 shows five supply series of Pacific Coast pears. The top deck contains three different series pertaining to California-produced fresh pears. One series represents interstate shipments of all California pears during the California Bartlett shipping
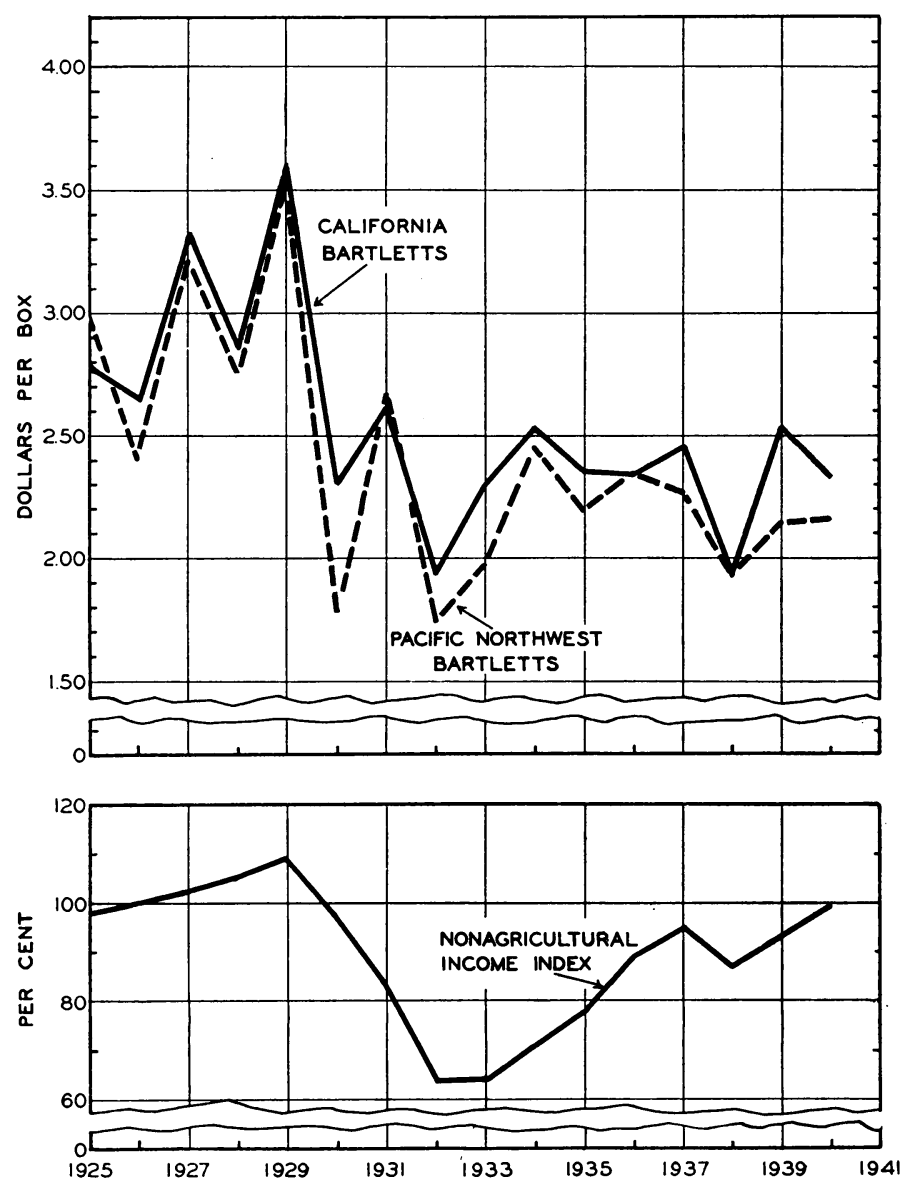

Fig. 9.-Auction prices of California and Pacific Northwest Bartlett pears, and index of United States nonagricultural income, 1925-1940.

Data from table 27 (p. 317).

season; the second series represents California Bartletts shipped fresh out of the state; and the third series represents California Bartletts sold on the seven major auction markets. ${ }^{31}$ The lower deck of figure 8 shows pear supplies from the Pacific Northwest (Oregon and Washington). One of the series indicates the volume of Pacific Northwest Bartletts used

\footnotetext{
${ }^{31}$ New York, Chicago, Boston, Philadelphia, Pittsburgh, St. Louis, and Cincinnati.
} 
fresh ; the other series measures Pacific Northwest shipments of all varieties of peairs only during the California Bartlett shipping season.

Prices of Pacific Coast Bartlett Pears.-Figure 9 shows two series of season's average prices of Pacific Coast Bartletts sold at auction. The California Bartlett prices are weighted averages of the season's prices on the seven major auction markets. The prices of the Pacific Northwest Bartletts are weighted-average prices on the New York auction. Pacific Northwest Bartletts are sold more in the Middle West than in the East; therefore New York auction prices may not be wholly representative of the bulk of sales. The prices shown in figure 9, however, serve for the purpose of indicating the general trends in the auction prices of California and Pacific Northwest Bartlett pears.

$\Lambda$ though the two price series in figure 9 follow a somewhat similar pattern, and with few exceptions the year-to-year changes are in the same direction, certain important characteristics merit attention. During the sixteen-year period, from 1925 to 1940, with the exception of four years, California Bartlett prices were above those of Pacific Northwest Bartletts. No doubt California Bartletts generally sell at a premium over Pacific Northwest Bartletts because the former are considered to be of superior quality. To that extent California and Pacific Northwest pears are not perfect substitutes. The lower deck of figure 9 shows the movement of the index of nonagricultural income payments in the United States from July through October.

\section{FACTORS AFFECTING CALIFORNIA BARTLETT PEAR PRICES}

The data shown in figures 8 and 9 are used in the following statistical analysis of factors affecting California Bartlett prices. Table 9 contains five different equations, each representing different characteristics of statistical demand functions for California fresh Bartlett pears. The general reasoning underlying the equations may be expressed as follows : Economic theory and market observation give grounds for expecting an increase in California Bartlett fresh supplies or auction sales to be associated with a decrease in their auction prices. Since Pacific Northwest pears shipped during the California Bartlett season may be expected to compete in consumption with California Bartletts, it is also logical to expect increased Pacific Northwest shipments to be associated with decreases in California Bartlett prices. Furthermore, the demand for California Bartletts may be expected to be positively correlated with variations in the level of consumers' money incomes. Finally, there is no doubt that influences other than the volume of pear supplies and income affect California Bartlett prices. Some of those other influences may be grouped into a catchall variable which may be presumed to change 


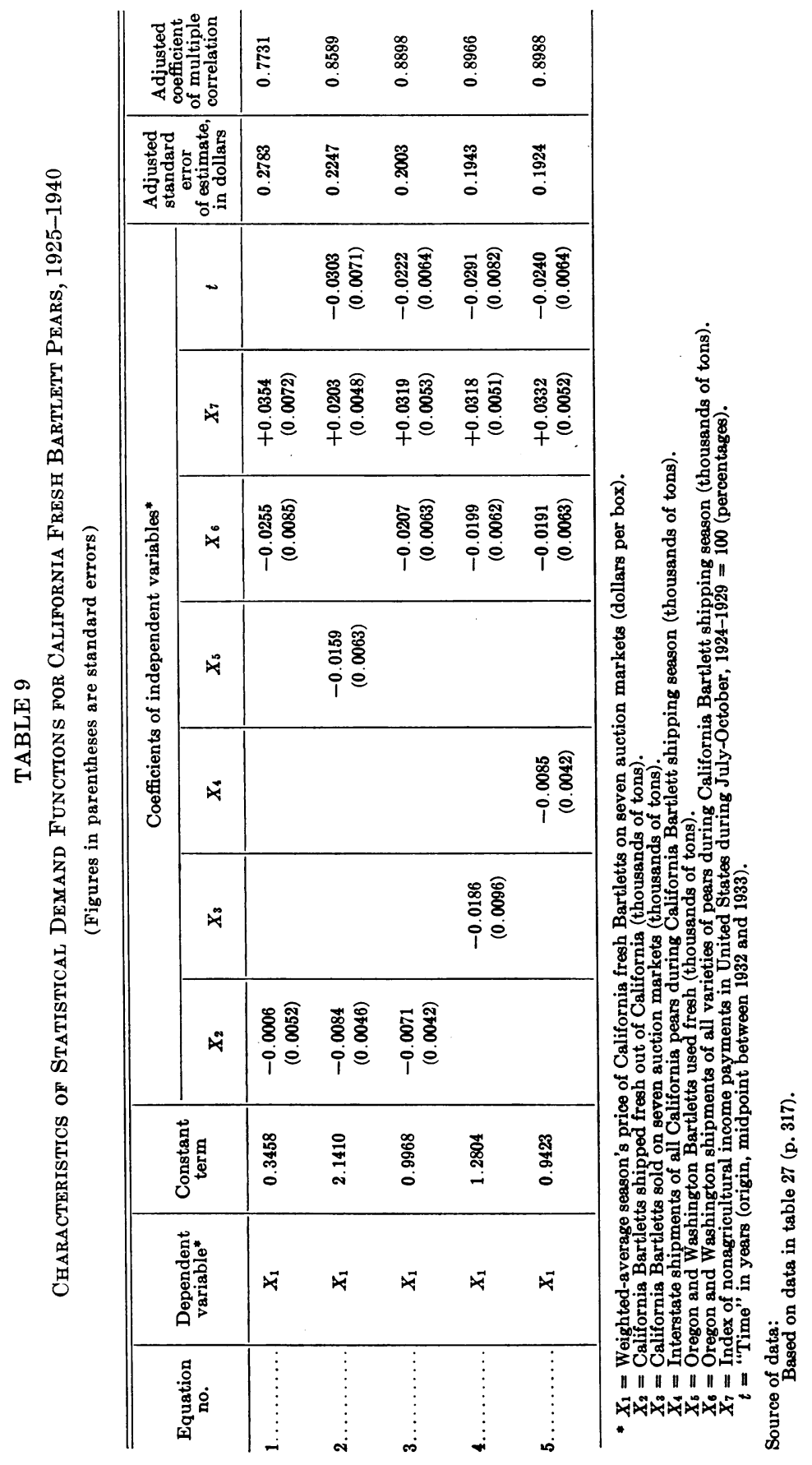


smoothly over time. Such a factor shall be termed "time" in the statistical analysis. Simultaneously considering the several preceding concepts, the hypothesis may be set up that California Bartlett prices are a function of the volume of California Bartlett shipments, the volume of competing pear supplies, the level of consumers' money income, and "time." Whether the inclusion of "time" will statistically improve the analysis must be judged from the results. But it must be emphasized that "time" is a catchall variable, the specific components of which are not isolated. The problem is to choose those specific measures of pear supplies which, in combination with other price influences, will adequately account for the determination of California Bartlett prices, and measure the separate price effects of the individual price determinants.

Regression Analysis of Factors Affecting Prices.-Examination of the various multiple correlation coefficients and standard errors of the equations in table 9 indicates that equations 4 and 5 yreld the best statistical explanation of the variation in California Bartlett prices, and equation 3 is only slightly less successful. In all of the equations in which "time" is an independent variable, its standard error is numerically less than the "time" net-regression coefficient. That is the statistical justification for retaining "time" in the analyses, and the omission of that variable would result in a lower adjusted multiple correlation coefficient. Equation 5 may be considered most desirable since both the Pacific Northwest shipments and those from California are for the same period, namely, during the California Bartlett shipping season. The signs of the netregression coefficients are consistent with the expected theoretical rela. tions between prices, supplies, and income outlined in the preceding paragraph. Furthermore, the net relation between price and "time" indicates that the demand for California fresh Bartletts has tended to decline during the past fifteen years - a situation which has been suspected by close observers of the industry.

The combined influences of the independent variables in equation 5 account for approximately 85 per cent of the variation in the dependent variable-season's weighted-average price of California fresh Bartletts on the seven chief auction markets. The inclusion of additional price influences such as supplies of related fruits, quality, and size of California Bartletts probably would decrease the amount of unexplained variation in the California Bartlett prices.

Since equation 5 and the others in table 9 are multiple linear regression equations, the question arises whether curvilinear net relations between the price and some of the independent variables would result in a better total fit or a better statistical explanation of the price variation. An answer to such a question may be obtained from examination of fig- 
ure 10. The solid line in each of the four sections of figure 10 shows graphically the net statistical relation between the price and each of the independent variables, respectively, in equation 5. 'The dots, one for each year, are obtained as follows : To the price estimated from the net linear relation between the price and an independent variable is added the difference between the actual price and that calculated from the total regression equation. If significant curvilinearity existed between the price and an independent variable, the dots in the corresponding section would exhibit a curvilinear relation. Examination of distribution of dots in each of the four sections of figure 10 gives no basis for suspecting that net curvilinear relations would significantly improve the statistical fit. Hence, there is a basis for retaining the net linear relations expressed by equation 5 instead of introducing multiple curvilinear regression.

Results of Regression Analysis.-In the upper deck of figure 11 are compared graphically the California Bartlett actual prices, and those calculated from equation 5 in table 9. In general the two price series move closely together. The extent of discrepancy is evident from the figure. The lower deck of figure 11 shows the calculated partial relations between the price and each of the independent variables, respectively, in equation 5 of table 9 . Thus, to restate the main results from the statistical analysis involving equation 5 the following are noted. During the 1925-1940 period, variation of four factors in combination accounted for 85 per cent of the variation in California Bartlett prices. The net statistical relations between the price and each of those factors may be expressed as follows: (1) With the other independent variables held constant, a change of 10,000 tons in the interstate shipments of all California pears during the California Bartlett shipping season was accompanied, on the average, by a change in the opposite direction of 8 cents a box in the auction price of California Barletts; (2) with the other independent variables held constant, a change of 10,000 tons in Oregon and Washington shipments of all varieties of pears during the California Bartlett shipping season was accompanied, on the average, by a change in the opposite direction of 19 cents a box in the auction price of California Bartletts ; (3) with the other independent variables held constant, a change of 10 points in the index of nonagricultural income payments was associated, on the average, with a change in the same direction of 33 cents a box in the auction price of California Bartletts; and (4) with the other independent variables held constant, a change of one unit or year in the "time" variable has, on the average, been accompanied by a change in the opposite direction of 2 cents a box in the auction price of California Bartletts. The relative importance of the price effects of the above four independent variables, respectively, may be indicated by the following 

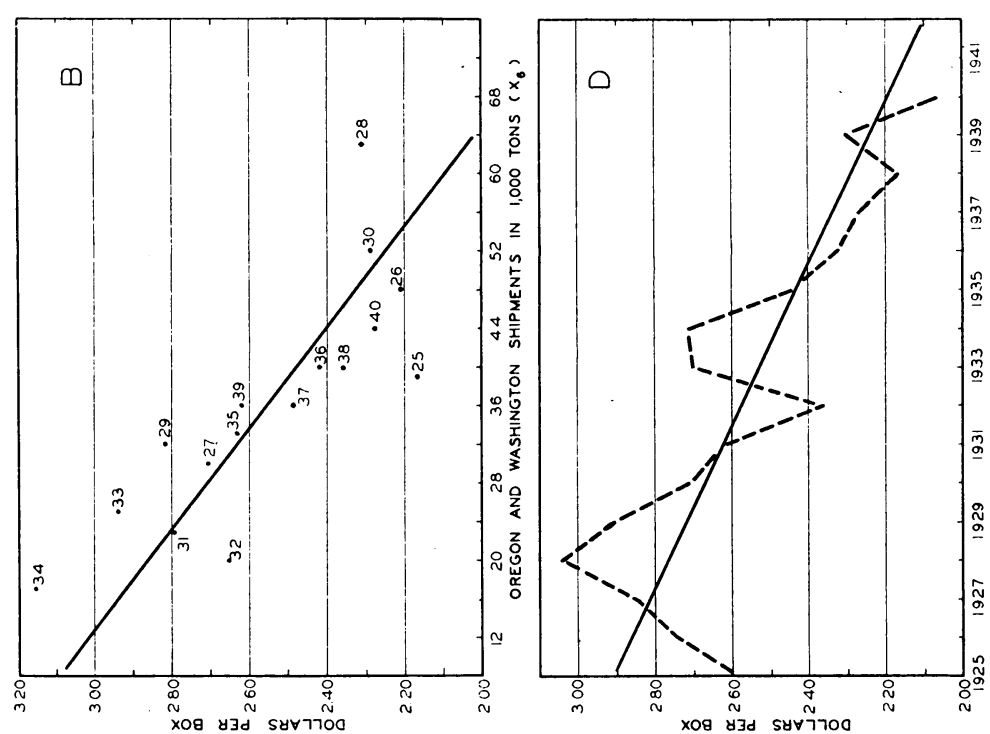

$\ddot{A} \tilde{m}$ is

10 : I

$\infty$ 용

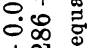

I พิ

Hi⿱

क्ष ||

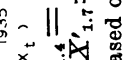

A

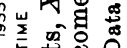

常

高

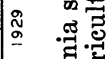

令

\%०

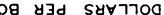

x09 43d ร4ทากาด0

$\ddot{\theta} \dot{0}$
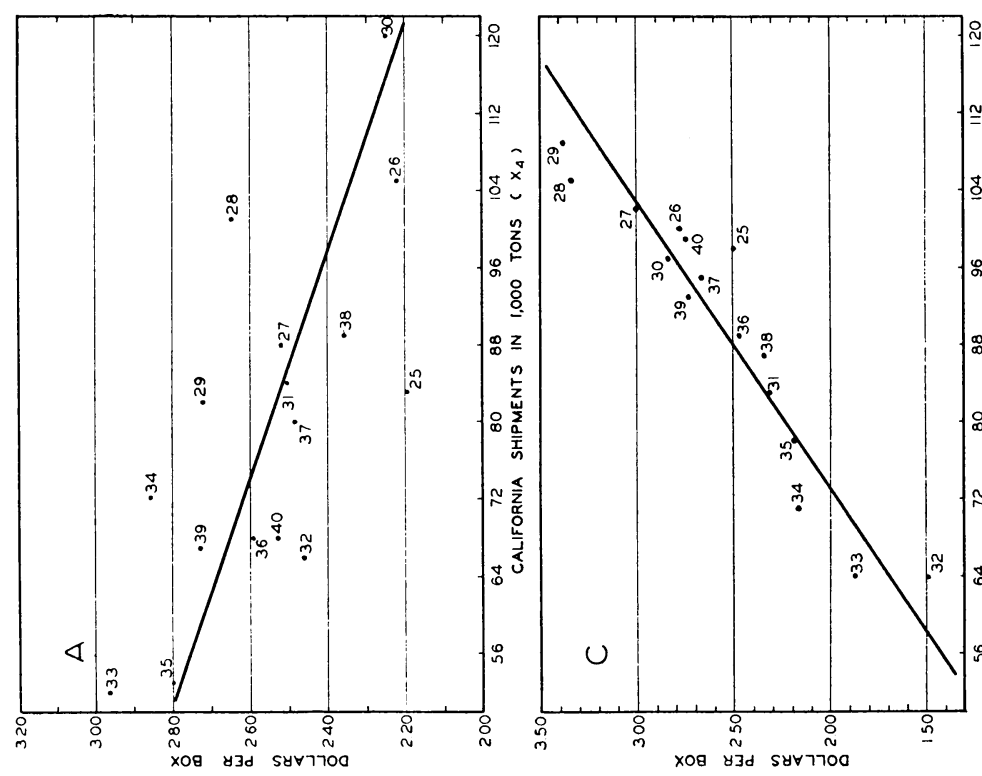

๖्त्त

2010

$\sim$ 年

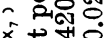

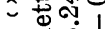

点些

ต

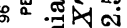

ํํำ

空

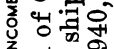

동형

年

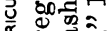

政

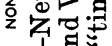

1. 0

so

Fin 
coefficients of separate determination, adjusted for sign : 0.068 for pear shipments from California ; 0.027 for shipments from Oregon and Washington; 0.532 for nonagricultural income; and 0.232 for the "time"

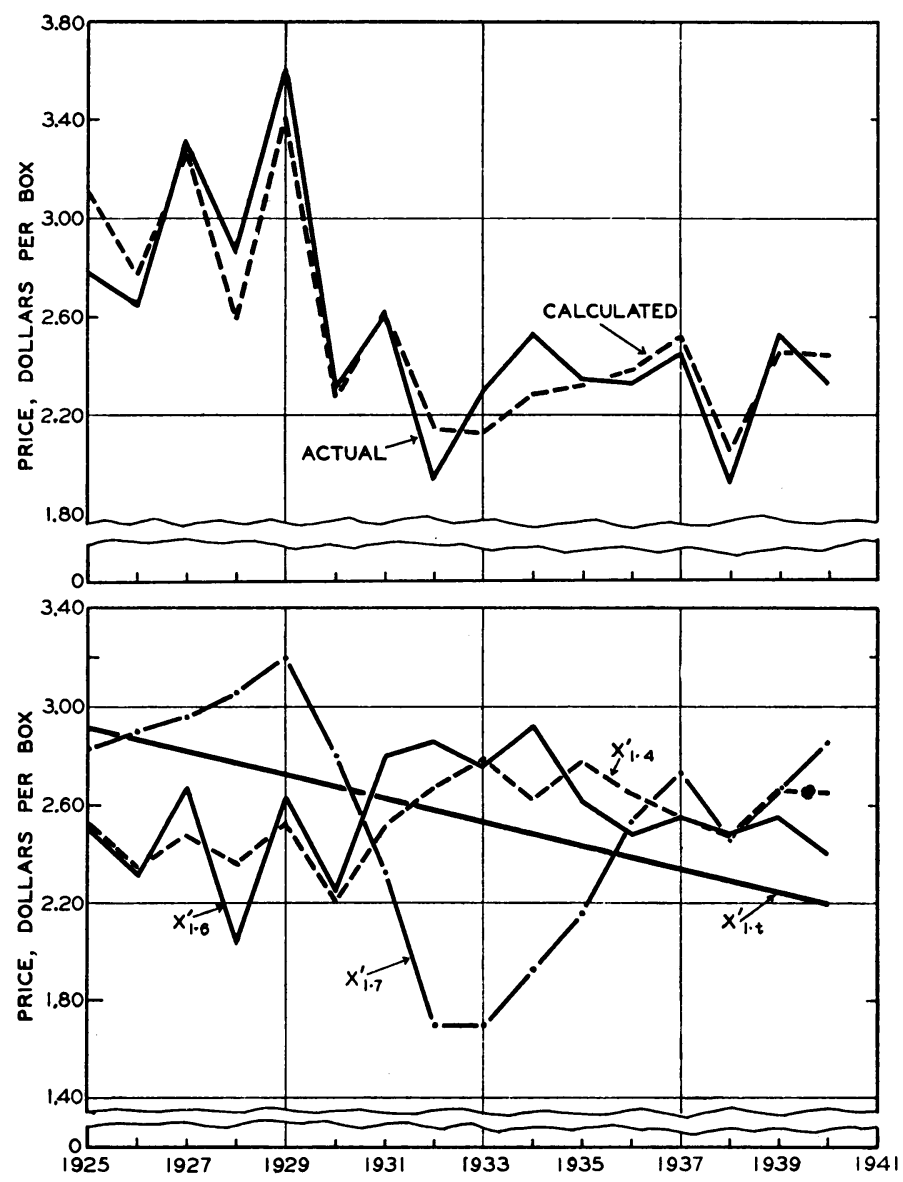

Fig. 11.-Actual and calculated auction prices of California Bartlett pears, and partial price effects of certain related factors, 19251940 .

Data based on table 9, equation 5 .

variable. Income has the relatively greatest price effect, and shipments from California have a relatively greater price effect than those from Oregon and Washington.

\section{FORMULATION OF MARKETING POLICIES}

Determination of Price Flexibilities.-In the formulation of marketing policies, special emphasis is attributed to the net or partial relation between proportional changes in price and associated proportional 
changes in quantity marketed or sold. In this connection the concepts of elasticity of demand with respect to price, and price flexibility with respect to quantity, are of considerable importance. The former is equal to the percentage change in quantity divided by the corresponding percentage change in price, and the latter is equal to the percentage change in price divided by the corresponding percentage change in quantity, where the changes in price and quantity are small and all other factors remained unchanged. Theoretically, elasticity of demand is equal to the reciprocal of price flexibility, and vice versa. However, in a statistical demand function determined by the least-squares method of regression, the inverse relation between elasticity of demand and flexibility of price does not strictly hold.The difficulty is a statistical problem which need not be of concern here..$^{32}$ In the multiple regression equation or statistical demand function discussed above (p. 282), price is the dependent variable, and therefore the appropriate measure of the relation between changes in price and quantity is the coefficient of price flexibility, indicated by the symbol $\phi$. Again using equation 5 in table 9 , it is stated that $\phi=\frac{\partial x_{1}}{\partial x_{4}} \cdot \frac{x_{4}}{x_{1}}$. The first fraction of this expression is obtained directly from the regression equation 5 and is equal to the net regression of $x_{1}$ on $x_{4}$, or 0.0085 . The numerator and denominator of the second fraction of $\phi$ vary as different points on the statistical demand function are used in computing the coefficient of price flexibility. This condition is stated, since it is not usually made clear that in all types of demand functions, except where the net relation between price and quantity is a straight line on double logarithmic paper, the coefficient of price flexibility (and elasticity of demand) varies from point to point on the demand function. Thus price flexibility pertains to a point on a demand function and not to the entire function. Only when the coefficient is the same for all points on the demand function is it strictly correct to state that the demand curve has a certain price flexibility. In general, the coefficient of price flexibility (and elasticity of demand) pertains to a specific point on the demand function.

Entirely as a matter of convention, the coefficient of price flexibility (and elasticity of demand) is often computed for that point on the demand function whose coördinates contain the means of the independent variables. Using equation 5 in table 9 , such a coefficient of price flexibility is computed. Substituting the means of the independent variables in the equation, the estimated price of $\$ 2.55$ is obtained, which is the denominator of the second fraction of $\phi=\frac{\partial x_{1}{ }^{\prime}}{\partial x_{4}} \cdot \frac{\bar{x}_{4}}{x_{1}{ }^{\prime}}$. The numerator of the second

\footnotetext{
${ }^{32}$ See: Schultz, Henry. The theory and measurement of demand. p. 225-29. University of Chicago Press, Chicago. 1938.
} 
fraction is the mean of $x_{4}$, or 79.875 ; and $\frac{\partial x_{1}{ }^{\prime}}{\partial x_{4}}$ is the net regression of $x_{1}$ on $x_{4}$, or - 0.0085 . Substituting these values in the equation for $\phi$, then $\phi=-0.2666$, which is equal to, at the point under consideration, the ratio of the relative change in price to the relative change in quantity with which it is associated, when the changes in price and quantity are small. Such a coefficient may be termed "average flexibility of price," although in fact it pertains to a single point on the statistical demand surface. The standard error of the coefficient may be computed ${ }^{33}$ and is equal to \pm 0.1097 . Hence for equation 5 , the coefficient of "average flexibility of price" and its standard error are written as $-0.2666 \pm 0.1097$.

TABLE 10

Calculated Coefficients of Price Flexibility, for California Bartlett Pears, 1925-1940

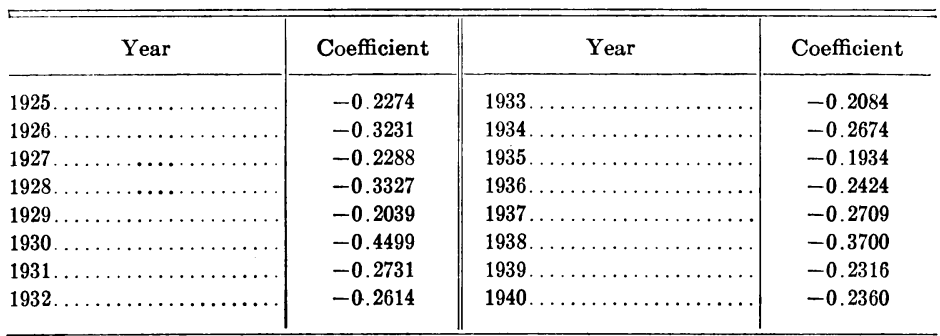

Source of data:

Computed from table 9 , equation 5 , by substituting the values of the independent variables which prevailed in the various years.

Price flexibilities have been computed for all the estimated prices during the 1925-1940 period. On the basis of equation 5, and substituting values of the independent variables which prevailed in the different years, the coefficients shown in table 10 have been obtained. The different coefficients illustrate the point noted above that the price flexibility varies from point to point on the demand surface. In this connection it is pertinent to mention that when the net relation between price and quantity is linear or the demand relation is expressed by a straight line, price flexibility varies inversely with the prices. High calculated prices are associated with low coefficients of price flexibility, and vice versa. This is necessarily characteristic of statistical demand functions yielding linear net relations between price and quantity.

Elastic Auction Demand for California Bartletts.- Since the coefficients of price flexibility for the individual years, and the "average flexibility of price" are all considerably less than 1, there is some basis

3:3 See: Mosak, Jacob L. Standard error of the coefficient of elasticity of demand. Jour. Amer. Stat. Assoc. 34:353-61. June, 1939. 
for concluding that the demand for Califoria fresh Bartlett pears in eastern auction markets is elastic within the range of the present observations. Acceptance of such a conclusion means that, other factors remaining unchanged, price decreases associated with sales increases would yield increased gross returns from auction sales. That does not necessarily imply, however, that corresponding demand at the farm, packing-house, or shipping point is elastic. In fact, the reverse may be true. Here the present authors wish only to point out that the evidence indicates that within the range of their observations, the auction-market demand for California Bartletts is elastic; other factors remaining constant, low prices and large sales would yield larger gross auction returns than high prices and small sales. The above analysis, however, is not adequate for determining the behavior of growers' or shippers' net auction returns, which are equal to gross returns minus costs.

Historically, low prices of California Bartletts were not associated with a larger volume of auction sales than high prices, nor were gross auction returns in years of low prices greater than in years of high prices. That fact, however, does not invalidate the above statistical analysis since factors such as consumers' income, competing supplies of other pears, and tastes have changed over time. Determination of the statistical net relation between California Bartlett supplies and prices involves holding all the other factors unchanged.

Gross Returns from Auction Sales.-The question arises, how did gross returns from the seven chief auction markets vary since 1925 ? Not only has the volume of auction sales of California fresh Bartletts decreased over the 1925-1940 period, but since 1932 the auction prices have generally been at a relatively low level. Decreased sales in conjunction with low prices: have resulted in decreased gross returns from auction sales. This situation is shown in figure 12, where gross returns from sales of California Bartletts on the seven chief auction markets are compared with the index of United States nonagricultural income payments for July-October. The two series are expressed in terms of 1924-1929 $=100$. Both gross returns and nonagricultural income declined sharply after 1929 to a low in 1933, but gross returns declined substantially more. The significant relation between the two series occurred after the 1933 low point. The income index steadily rose until in 1937 it had reached 95 per cent of the 1924-1929 level; a drop in 1938 was followed by advances so that by 1940 the income index was at 99 per cent of the 1924-1929 level. This recovery was not evident in gross returns from auction sales. Since 1932, gross returns have fluctuated about a level of approximately 57 per cent of average annual returns for the 1924-1929 period. The significant indication is that the California fresh Bartlett industry, 
judged on the basis of gross returns from the leading auction markets, has failed by far to regain its pre-Depression status. This situation may be due to many influences such as (1) increased competition from Pacific Northwest Bartletts which are on the market during the latter half of the California shipping period, (2) increased competition from other fresh fruits such as plums and peaches, (3) greater consumption of fall

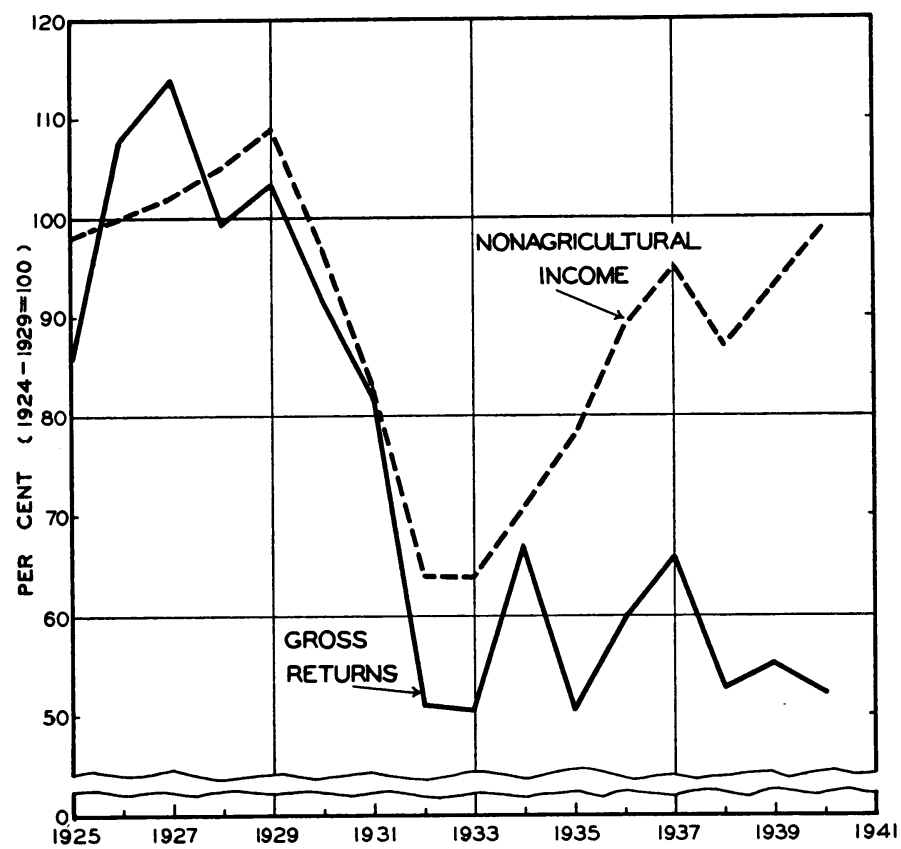

Fig. 12.-Gross returns from California Barlett pears on seven major auction markets and United States nonagricultural income payments, $1925-1940$.

Data from tables 27 and 28 (p. 317 and 319 ).

and winter pears with a decline in the consumption of California Bartletts, and (4) changes in consumers' tastes, attitudes, and habits. Clearly during the past decade the California fresh Bartlett industry has experienced a period during which important industry problems have become evident.

\section{SUMMARY AND CONCLUSIONS}

The pronounced seasonal variation in the weekly auction prices of California fresh Bartlett pears is directly related to the marked seasonal tendency in their shipments and auction sales. The seasonal patterns in sales and prices are inverse, but do not correspond perfectly; auction sales usually reach their maximum volume in the fourth or fifth week of the marketing season, and prices reach the lowest point during the in- 
terval from the third to the sixth week. The seasonal variations in sales and prices do not perfectly correspond in any two seasons, but in all years the timing and magnitude of weekly changes in sales and prices follow a definite pattern. During the past two decades there has been a tendency towards smaller fluctuations in weekly auction sales and prices within the season. Prices for various weeks in the marketing season have deviated less from the season's average price in recent years than they did twelve or fifteen years ago. Such a change is most highly pronounced in the prices of the last quarter of the season. Hence there has been a shift in the pattern of seasonal variation in weekly prices. Although weekly prices of individual sizes of Bartletts vary among themselves, the prices of particular sizes follow a pattern of seasonal movement that is very similar to the seasonal variation in the weighted-average weekly prices of all sizes.

Season's average prices in various auction markets closely approximate each other. Although no single market consistently has the highest or lowest season's price, New York prices were either highest or second highest in all of the past sixteen years. The weekly prices in different auction markets follow broadly similar patterns of seasonal movement, but in some weeks prices in one market deviate widely from those in other markets. The weekly prices in each market appear to be influenced not only by its own position with respect to supplies of Bartletts and other fruits, but also by the situations in other markets and the price influences that affect all markets.

Examination of the relations of pears to other fresh fruit indicates that fresh plums and fresh peaches compete with California fresh Bartletts in consumption. The relation between Bartlett pears and oranges, however, is not so clear. There is considerable evidence that fresh pears and oranges are noncompeting in consumption. The character of such relations between pears and other fruits should be considered in the formulation and management of pear-marketing agreements and policies. In recent years there has been a decline in the sales and per-capita consumption of California Bartletts, and this decline may be partly due to the increase in the consumption of other fruits.

The annual changes in auction-market prices of California Bartletts during the 1925-1940 period have been primarily determined by variations in the following four major price influences : (1) the level of nonagricultural income payments in the United States; (2) the volume of California fresh pair interstate shipments during the California Bartlett shipping season; (3) the volume of Oregon and Washington interstate shipments of fresh pears during the California Bartlett shipping season; and (4) a straight-line "time" trend representing a persistent 
shift in the auction-market demand for California fresh Bartletts. A change of 10,000 tons in California interstate shipments of pears during the California Bartlett season was accompanied, on the average, by a change in the opposite direction of about 8 cents a box in the auction price of California Bartletts. A change of 10,000 tons in Oregon and Washington shipments of pears during the California Bartlett shipping season was accompanied, on the average, by a change in the opposite direction of about 19 cents a box in the auction price of California Bartletts. $A$ change of 10 points in the index of nonagricultural income payments was associated, on the average, with a change in the same direction of about 33 cents a box in the auction price of California Bartletts. Also during the 1925-1940. period there has occurred a decrease in the auctionmarket demand for California Bartletts. Other influences, such as the volume and prices of related fruits and products, the distribution of supplies in various market areas, the quality and size distribution of California Bartletts of the individual years, and the general level of wholesale prices have also affected auction-market prices of California Bartletts.

Statistical-demand analysis indicates that the auction-market demand for California Bartletts is elastic. Other influences remaining unchanged, a small decrease in auction price is assqciated with a proportionately larger increase in auction sales, and an increase in auction gross returns ; a small increase in auction price is associated with a proportionately larger decrease in auction sales, and a decrease in auction gross returns.

\section{$\triangle$ CKNOWLEDGMENTS}

The authors appreciate the helpful suggestions of their colleagues, Dr. H. R. Wellman and Dr. George Kuznets. The late Dr. Carl L. Alsberg, Director of the Giannini Foundation of Agricultural Economics of the University of California, also made valuable comments during the course of the study.

Special acknowledgment is given to the various agencies and individuals who were extremely helpful in connection with compilation and interpretation of much of the statistical data on which the study is based. The authors have attempted to designate as far as possible the contributing agencies and persons in the footnotes to the tables.

Mr. Gordon Ockey of the Farm Credit $\Lambda$ dministration, Berkeley, California; Mr. H. H. Stippler of the United States Bureau of Agricultural Economics, Berkeley, California ; and Mr. Richard Bylin and Mr. Jerry Foytik, both of the Surplus Marketing Administration, Washington, D. C., made suggestive comments on parts of an early draft of the manuscript. Mr. Frank Swett was particularly helpful with his firsthand information on the California pear industry. 


\section{APPENDIX A}

\section{TRENDS IN RATIOS OF PRICES AND UNLOADS}

As noted in the text (p. 268-69), tests 1 and 2 on related demands use prices and quantities pertaining to the New York market. The prices of California Bartletts, California plums (most important varieties), and California Valencia oranges are weighted-average auction-market prices for the two months July and August from 1924 through 1938. The corresponding quantities of the four fruits are unloads during July and August in New York. Although the data are referred to as pertaining to New York City, in fact they are representative of what may be termed the "New York market area." New York unloads supply the environs of New York, and the corresponding prices are a measure of the wholesale prices of the New York market area.

The auction prices of Bartletts, plums, and Valencia oranges were originally on a box basis, whereas the original wholesale peach prices were those of less-than-carlot 6 -basket carriers. They were converted to dollars per 100 pounds in order to have the prices of the four fruits expressed in a common unit. For a similar reason all unloads were converted from a car basis to tons.

In using test 1 to determine the relations in consumption between pears and the three other fruits-plums, peaches, and oranges-the ratios were adjusted for secular trend. The trends adjusted for in both the price ratios and the quantity ratios were such that the adjusted ratios were substantially free of a rising or declining trend and fluctuated about a horizontal one. Schultz ${ }^{34}$ used the ratio test (test 1 ) based on the relations between the coefficient of variation of the price ratios and the corresponding coefficient of the quantity ratios. Although he realized and stated that trends should be eliminated from the ratios before the cofficients of variation were computed, he actually did not do so on the grounds that later he was to apply "more refined tests to the same data." Nevertheless, he comments on some of his results with the suggestion that if the trends were eliminated from the ratios a different type of relation might result.

In the price ratios, the plum, peach, and orange prices, respectively, were divided by the pear price. Similarly, to obtain the quantity ratios the unloads of plums, peaches, and oranges, respectively, were divided by the pear unloads. The price ratios and unload ratios were adjusted for the trends expressed by the following mathematical equations where $y$

${ }^{34}$ Schultz, Henry. The theory and measurement of demand. p. 570-604. University of Chicago Press, Chicago. 1938. 
stands for price ratios, $x$ stands for unload ratios, and $t$ stands for time in years :

(1) Plum price to pear price,

$y=113.280+2.393^{t}$; origin at 1923 .

(2) Plum unloads to pear unloads, $x=(21.186)(1.104)^{t}$; origin at 1924 .

(3) Peach price to pear price, $y=65.939+3.088^{t}$; origin at 1923 .

(4) Peach unloads to pear unloads, $x=180.058+5.953^{t}$; origin at 1923 .

(5) Orange price to pear price, no trend eliminated.

(6) Orange unloads to pear unloads, $x=69.793+15.902^{t}$; origin at 1923 .

The actual price and quantity ratios were expressed as percentages of the above corresponding trends, and from the adjusted ratios were computed coefficients of variation and their standard errors. The final results were given and discussed on page 272 . 


\section{APPENDIX B}

\section{THE RELATIONS OF PEARS TO PLUMS, PEACHES, AND ORANGES BASED ON LINEAR ARITHMETIC DEMAND FUNCTIONS ${ }^{35}$}

In the section on "Relations between Pears and Other Fresh Fruits," test 2 (p. 273) is based on linear arithmetic demand functions given in table 11.

Equations 1, 3, and 5 in table 11 express the price of pears as functions of pear unloads; the unloads of the three other fruits, respectively; an index of New York state factory wages ; and "time." Equations 2, 4, and 6 express the prices of plums, peaches, and oranges, respectively, as functions of pear unloads; the index of New York state factory wages; and "time." In each of the equations a closed system is assumed. Pears are undoubtedly related in demand with many fruits other than the three particular ones considered. The inclusion of more variables in the multiple regression equations would drastically reduce the number of degrees of freedom. The fits of the equations, as measured by the adjusted multiple correlation coefficients, adjusted standard errors of estimate, and standard errors of the net-regression coefficients, are only fair ; but perhaps sufficient to give a qualitative indication of the related demands.

The unloads and prices in the multiple regression equations are the same data on which the ratio test 1 (p. 272) is based. They pertain to New York during July and August from 1924 through 1938. The measure of wages was computed from monthly factory wages in New York state based on the week in which the fifteenth of the month falls. An arithmetic average of the three monthly values-June, July, and August-may be viewed as a measure of income during the June-August interval. Although the prices and unloads are those of July and August, June wages were included with those of the following two months on the grounds that the effect of wages in June carries over into the immediately succeeding months. The factory wages are not wholly representative of purchasing power in the New York city area for at least two reasons. First, the factories from which the wage data are collected are not limited to the New York city area. Secondly, sources of income other than factory wages should be included in an adequate measure of consumers' income. To what extent the state factory wages are correlated with consumers' incomes in the New York city area is not known, but no doubt there is considerable correlation. Although the measure of income used is not all that one might desire, it is the best available index of income in New York. Probably if a more adequate measure of consumers' income in

${ }^{35}$ See: Hoos, Sidney. An investigation on complementarity relations between fresh fruits. Jour. Farm Econ. 23(2) :421-33. May, 1941. 


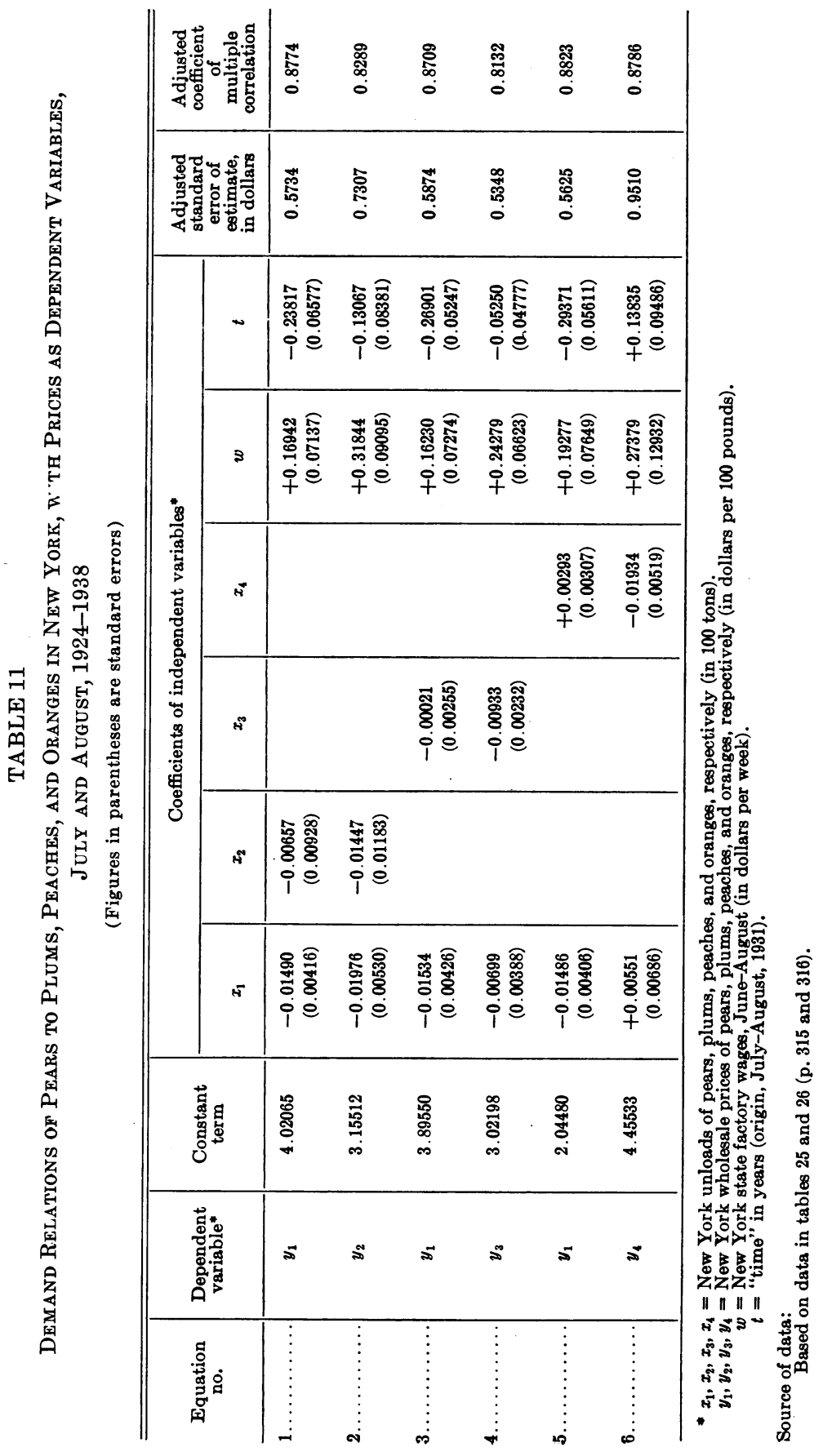




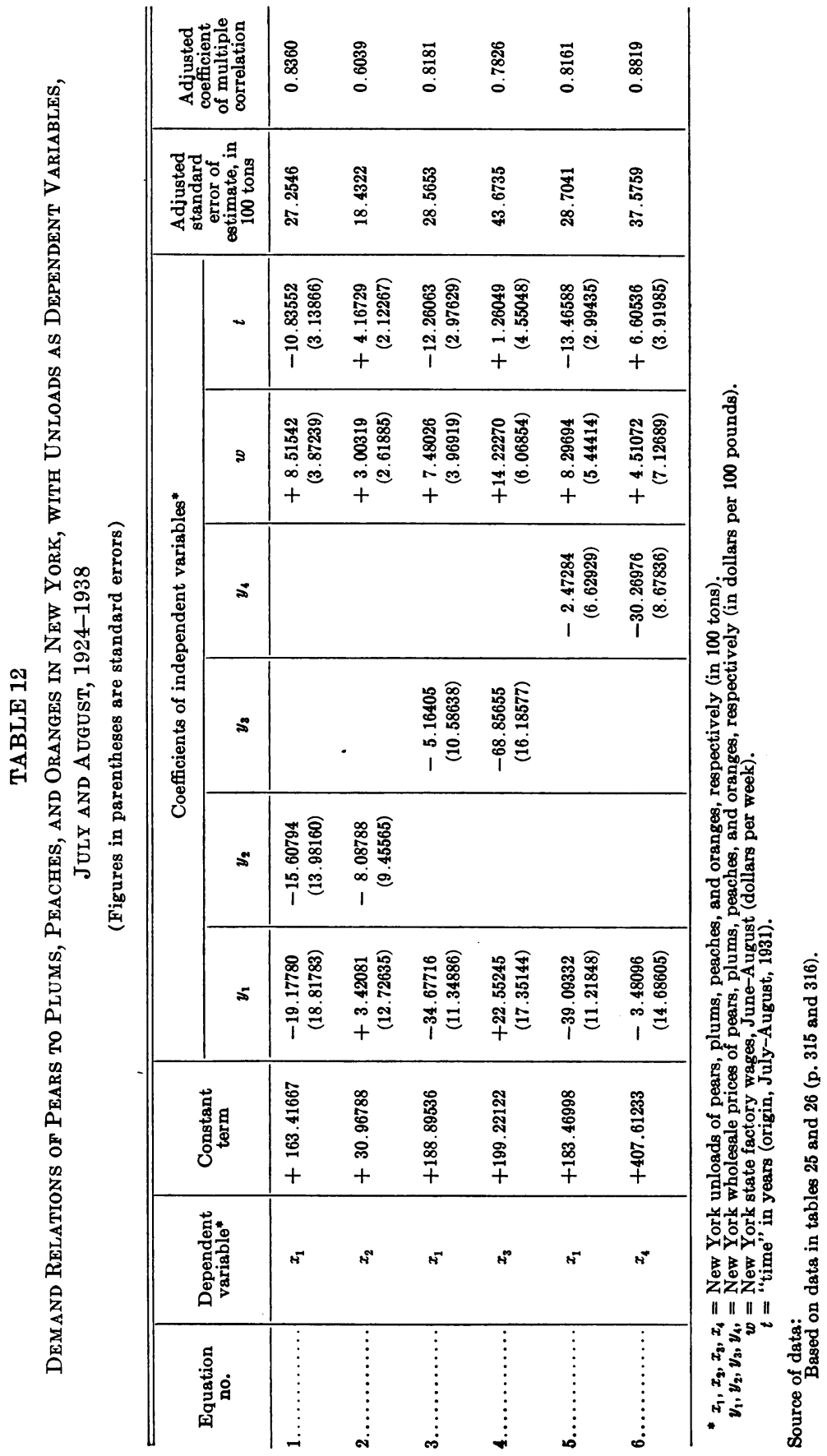


New York were available, the regression equations expressing the related demands would give a better fit.

Test 2 (p. 273) has two limitations. First is the assumption that utility is measurable; second is the assumption that the marginal utility of money is constant. This second limitation, which is equivalent to the assumption that the amount of money a consumer allocates to the good is such a small part of his income that the marginal degree of utility of his expenditures is constant, is not serious in connection with individual fresh fruits. The expenditure on consumption of fresh pears, peaches, plums, or oranges is probably such a small proportion of the total income of consumers that the marginal degree of utility of money may be neglected. But both limitations can be overcome by resorting to another test, the Slutsky conditions of related demand. ${ }^{36}$

The Slutsky criterion of related demands has been applied here to the relations of pears to plums, peaches, and oranges. The equations in table 12 were used since the general theoretical conditions of the test may be calculated more easily when quantities are the dependent variables, although better fits were obtained with prices considered as the dependent variables.

The results for the two pairs of commodities, pears and plums, and pears and peaches, were disappointing since the two sides of the Slutskycondition equations did not agree even in sign. This ambiguity may be due to the low correlations of at least one of the two multiple regression equations from which the relations of the pairs of goods are determined. In connection with pears and oranges, the results of the Slutsky condition are consistent with the previous tests, and the indications again are that pears and oranges are not competing in consumption.

\footnotetext{
${ }^{38}$ See: Hicks, J. R. Value and capital. p. 307-14. Oxford University Press, Oxford. 1939.

Also: Schultz, Henry. The theory and measurement of demand. p. 620-47. University of Chicago Press. Chicago, 1938.

For comments on the statistical significance of the Slutsky-condition results, see: Kozlik, Adolph. An investigation on complementarity relations between fresh fruits: A reply. Jour. Farm Econ. 23(2):654-56. August, 1941.
} 
APPENDIX C

BASIC TABLES 


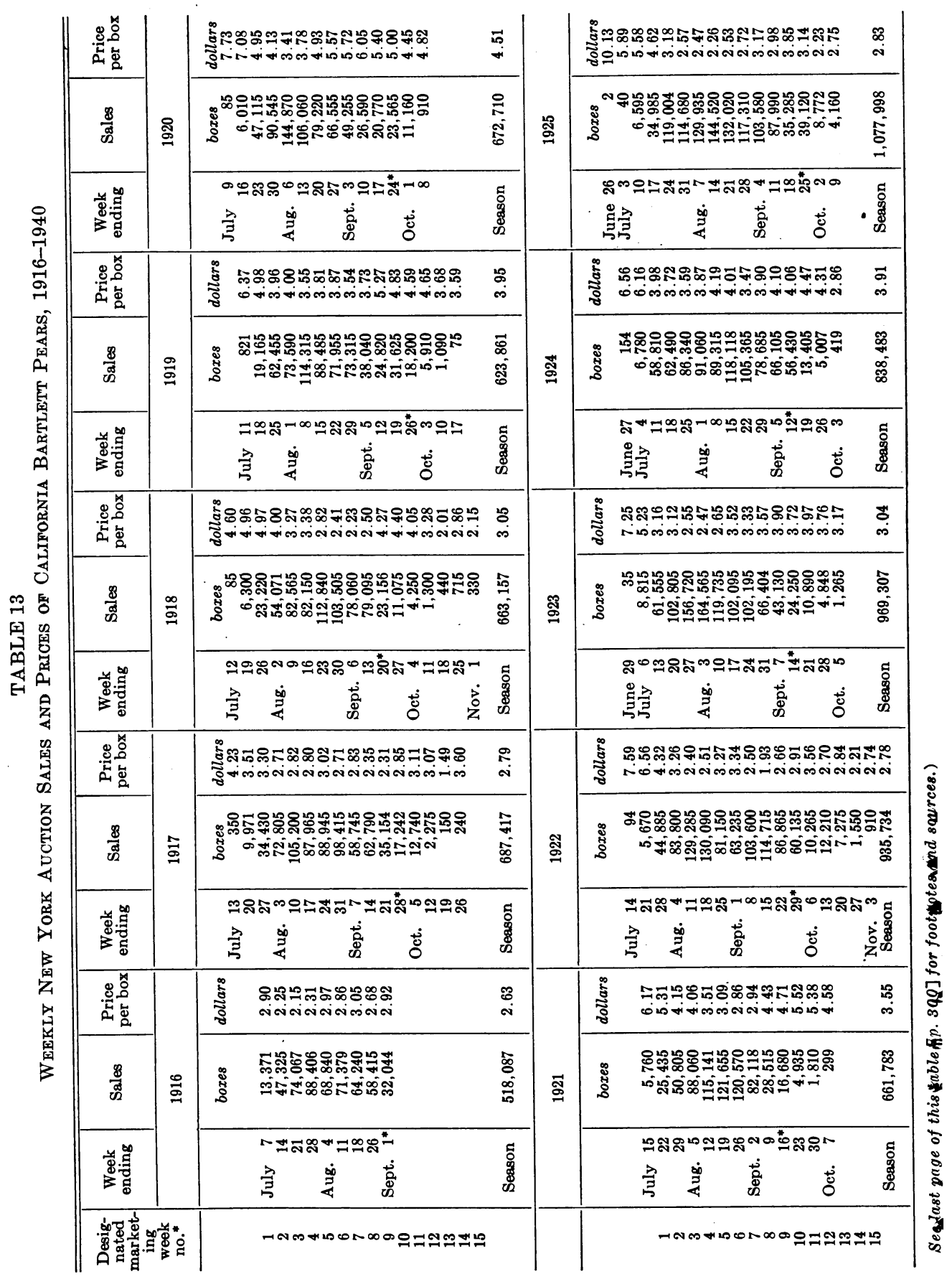




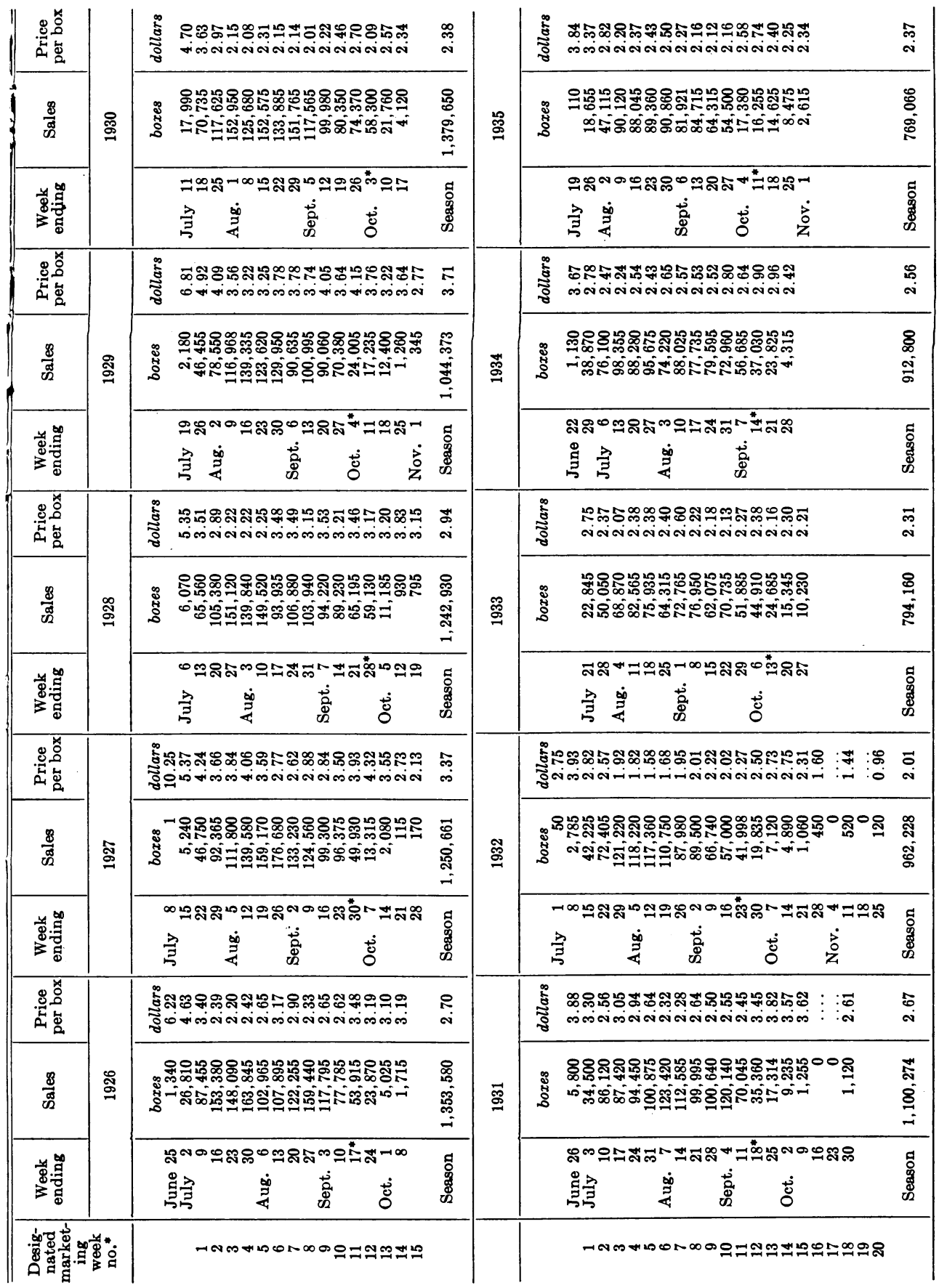




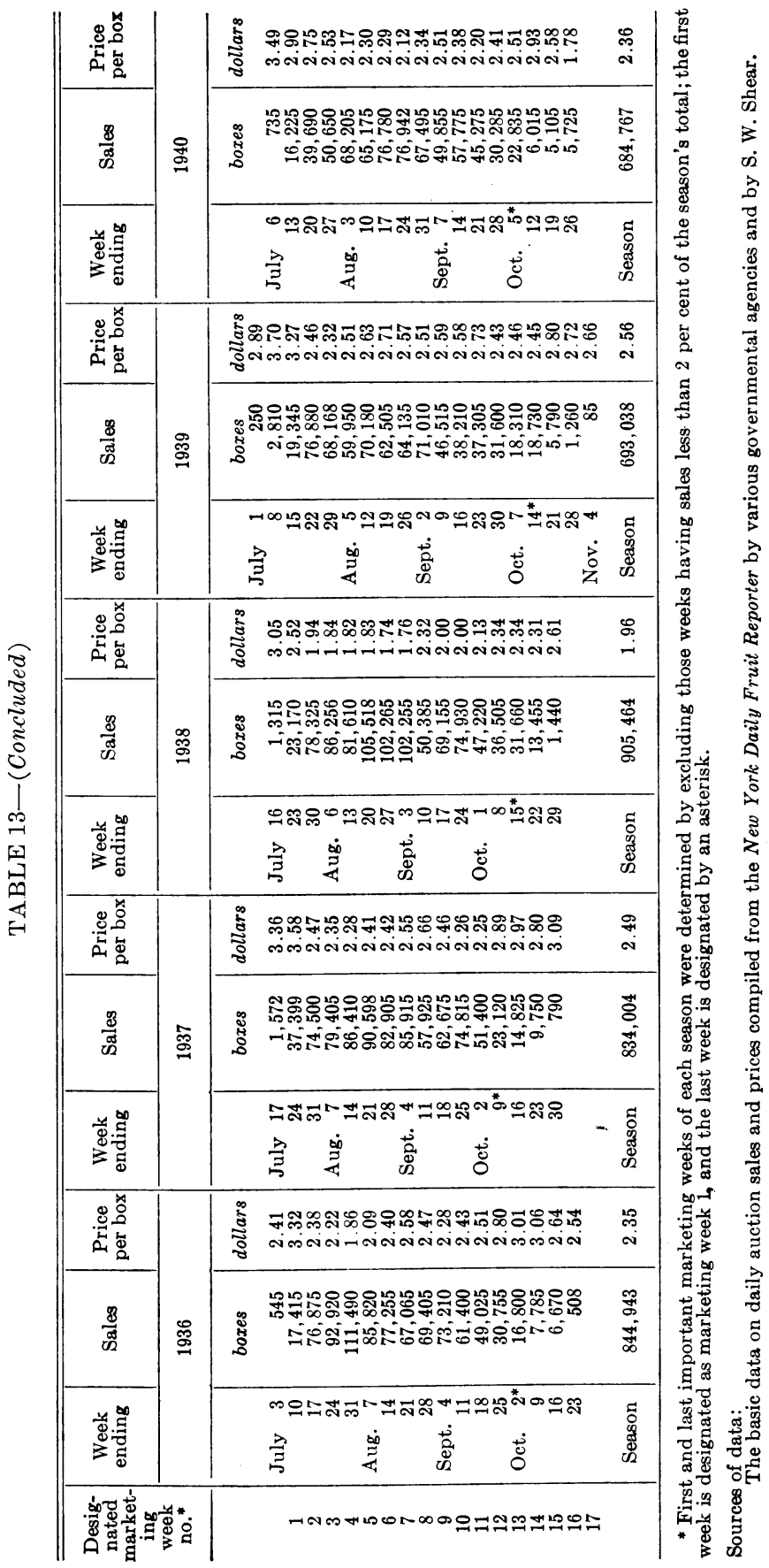


TABLE 14

P'rikcentracifi Weekly Volume of Season's Average Weekly New York Auction SAles* OF' CALifornia Bartlett Pears, 1916-1940

\begin{tabular}{|c|c|c|c|c|c|c|c|c|c|c|c|c|c|}
\hline 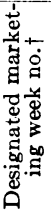 & 1916 & 1917 & 1918 & 1919 & 1920 & 1921 & 1922 & 1923 & 1924 & 1925 & 1926 & 1927 & 1928 \\
\hline & $\begin{array}{c}\text { per } \\
\text { cent }\end{array}$ & $\begin{array}{c}\text { per } \\
\text { cent }\end{array}$ & $\begin{array}{c}\text { per } \\
\text { cent }\end{array}$ & $\begin{array}{l}\text { per } \\
\text { cent }\end{array}$ & $\begin{array}{l}\text { per } \\
\text { cent }\end{array}$ & $\begin{array}{c}\text { per } \\
\text { cent }\end{array}$ & $\begin{array}{l}\text { per } \\
\text { cent }\end{array}$ & $\begin{array}{l}\text { per } \\
\text { cent }\end{array}$ & $\begin{array}{c}\text { per } \\
\text { cent }\end{array}$ & $\begin{array}{l}\text { per } \\
\text { cent }\end{array}$ & $\begin{array}{c}\text { per } \\
\text { cent }\end{array}$ & $\begin{array}{c}\text { per } \\
\text { cent }\end{array}$ & $\begin{array}{c}\text { per } \\
\text { cent }\end{array}$ \\
\hline & & 1 & $\ddagger$ & & $\ddagger$ & & $\ddagger$ & $\ddagger$ & 1 & $\begin{array}{l}t \\
\ddagger\end{array}$ & 1 & $\ddagger$ & \\
\hline & & 15 & 8 & 1 & 9 & 8 & 6 & 9 & 7 & 7 & 23 & 4 & 6 \\
\hline 1 & 23 & 52 & 33 & 34 & 72 & 35 & 50 & 65 & 72 & 36 & 75 & 41 & 65 \\
\hline 2 & 82 & 110 & 77 & 112 & 139 & 71 & 93 & 109 & 76 & 124 & 130 & 83 & 104 \\
\hline 3 & 129 & 159 & 117 & 131 & 221 & 122 & 144 & 166 & 106 & 119 & 125 & 100 & 148 \\
\hline 4 & 153 & 133 & 116 & 204 & 162 & 160 & 145 & 174 & 112 & 135 & 139 & 125 & 137 \\
\hline 5 & 120 & 134 & 159 & 158 & 121 & 169 & 90 & 127 & 110 & 150 & 87 & 142 & 146 \\
\hline 6 & 124 & 149 & 146 & 128 & 102 & 167 & 71 & 108 & 145 & 137 & 92 & 158 & 93 \\
\hline 7 & 112 & 89 & 110 & 131 & 75 & 115 & 116 & 108 & 130 & 122 & 104 & 120 & 105 \\
\hline 8 & 102 & 95 & 111 & 68 & 40 & 39 & 128 & 70 & 97 & 108 & 136 & 112 & 102 \\
\hline 9 & $56 \dagger$ & 53 & $33 \dagger$ & 44 & 32 & $23 \dagger$ & 97 & 46 & 81 & 91 & 100 & 88 & 93 \\
\hline 10 & & $26 \dagger$ & 16 & 56 & $36 \dagger$ & 6 & $67 \dagger$ & $26 \dagger$ & $69 \dagger$ & 37 & 66 & 86 & 88 \\
\hline 11 & & 19 & 6 & $33 \dagger$ & 17 & 3 & 11 & 12 & 16 & $41 \dagger$ & $46 \dagger$ & $45 \dagger$ & 63 \\
\hline 12 & & 3 & 2 & 11 & 1 & $\ddagger$ & 14 & 5 & 6 & 9 & 21 & 12 & $57 \dagger$ \\
\hline 13 & & $\ddagger$ & 1 & 2 & & & 8 & 1 & $\ddagger$ & 4 & 5 & 2 & 11 \\
\hline 14 & & $\ddagger$ & 1 & $\ddagger$ & & & 2 & & & & 1 & $\ddagger$ & 1 \\
\hline \multirow[t]{5}{*}{15} & & & $\ddagger$ & & & & 1 & & & & & $\ddagger$ & 1 \\
\hline & 1929 & 1930 & 1931 & 1932 & 1933 & 1934 & 1935 & 1936 & 1937 & 1938 & 1939 & 1940 & \\
\hline & $\begin{array}{c}\text { per } \\
\text { cent }\end{array}$ & $\begin{array}{c}\text { per } \\
\text { cent }\end{array}$ & $\begin{array}{c}\text { per } \\
\text { cent }\end{array}$ & $\begin{array}{c}\text { per } \\
\text { cent }\end{array}$ & $\begin{array}{l}\text { per } \\
\text { cent }\end{array}$ & $\begin{array}{c}\text { per } \\
\text { cent }\end{array}$ & $\begin{array}{l}\text { per } \\
\text { cent }\end{array}$ & $\begin{array}{c}\text { per } \\
\text { cent }\end{array}$ & $\begin{array}{c}\text { per } \\
\text { cent }\end{array}$ & $\begin{array}{c}\text { per } \\
\text { cent }\end{array}$ & $\begin{array}{c}\text { per } \\
\text { cent }\end{array}$ & $\begin{array}{c}\text { per } \\
\text { cent }\end{array}$ & \\
\hline & & & & $\ddagger$ & & & & & & & 1 & & \\
\hline & 2 & 16 & 7 & 3 & & 2 & $\ddagger$ & 1 & 2 & 2 & 6 & 1 & \\
\hline 1 & 51 & 63 & 39 & 50 & 39 & 53 & 30 & 27 & 56 & 34 & 40 & 32 & \\
\hline 2 & 85 & 105 & 97 & 86 & 85 & 103 & 76 & 120 & 111 & 115 & 158 & 77 & \\
\hline 3 & 127 & 138 & 98 & 144 & 116 & 134 & 146 & 146 & 118 & 126 & 140 & 99 & \\
\hline 4 & 152 & 113 & 106 & 141 & 140 & 120 & 142 & 175 & 128 & 119 & 123 & 133 & \\
\hline 5 & 135 & 138 & 114 & 139 & 128 & 130 & 144 & 135 & 135 & 154 & 144 & 127 & \\
\hline 6 & 141 & 120 & 139 & 131 & 109 & 101 & 147 & 121 & 123 & 150 & 128 & 150 & \\
\hline 7 & 99 & 136 & 127 & 105 & 123 & 120 & 132 & 105 & 128 & 149 & 131 & 150 & \\
\hline 8 & 110 & 105 & 113 & 106 & 130 & 106 & 137 & 109 & 86 & 74 & 146 & 132 & \\
\hline 9 & 98 & 90 & 113 & 79 & 105 & 108 & 104 & 115 & 93 & 101 & 95 & 97 & \\
\hline 10 & 77 & 72 & 135 & 67 & 120 & 99 & 88 & 96 & 111 & 110 & 78 & 113 & \\
\hline 11 & $26 \dagger$ & 67 & 79 & $50 \dagger$ & 88 & 77 & 28 & 77 & 76 & 69 & 76 & 88 & \\
\hline 12 & 19 & $52 \dagger$ & $40 \dagger$ & 24 & 76 & $50 \dagger$ & $26 \dagger$ & 48 & $34 \dagger$ & 53 & 65 & 59 & \\
\hline 13 & 13 & 20 & 19 & 8 & $42 \dagger$ & 32 & 24 & $26 \dagger$ & 22 & $46 \dagger$ & 38 & 44 & \\
\hline 14 & 1 & 4 & 10 & 6 & 26 & 6 & 14 & 12 & 14 & 20 & $38 \dagger$ & 12 & \\
\hline 15 & $\ddagger$ & & 1 & 1 & 17 & & 4 & 10 & 1 & 2 & 12 & 10 & \\
\hline 16 & & & 0 & $\ddagger$ & & & & 1 & & & 3 & 11 & \\
\hline 17 & & & 0 & 0 & & & & & & & $\ddagger$ & & \\
\hline 18 & & & 1 & 1 & & & & & & & & & \\
\hline 19 & & & & 0 & & & & & & & & & \\
\hline 20 & & & & $\ddagger$ & & & & & & & & & \\
\hline
\end{tabular}

* Data on sales for the various weeks of each year are percentages of the average weekly sales during the weeks in which most of the sales are made; the proportion of sales included in these important marketing weeks varies from 96 to 99 per cent and the number of weeks from 9 to 14

$\dagger$ First and last important marketing weeks of each season were determined by excluding those weeks having sales less than 2 per cent of the season's total; the first week is designated as marketing week 1 , and the last week is designated by a dagger.

† Less than 0.5 per cent.

Source of data:

Based on data in table 13. 
TABLE 15

Percentage Weekly Prices of Season's Weighted-Average New York Auction Prices of California Bartlett Pears, 1916-1940

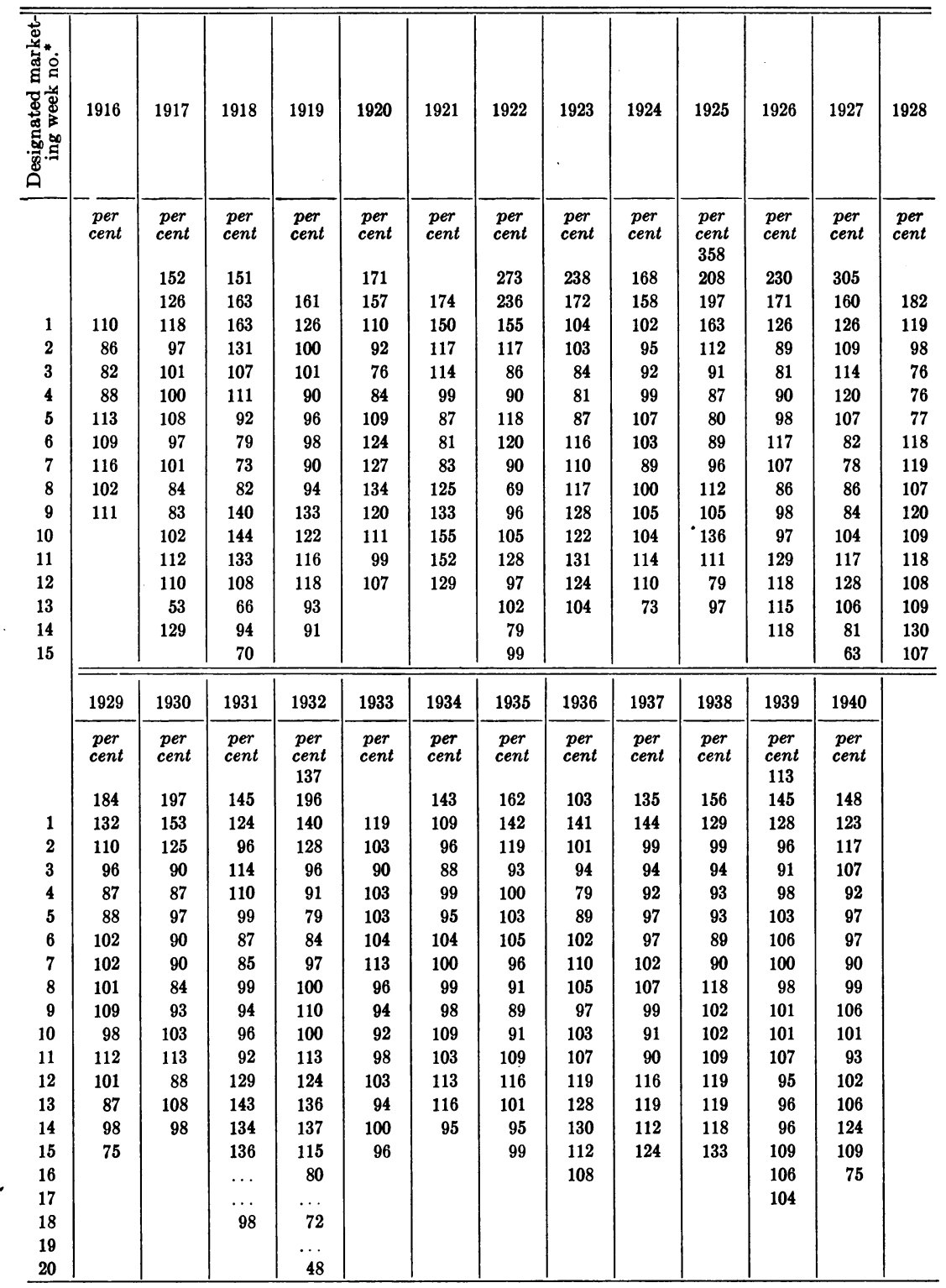

* First important marketing week of each season was determined by excluding those weeks having sales less than 2 per cent of the season's total.

Source of data:

Based on data in table 13. 


\section{TABLE 16}

Season's Weighted-Average New York Auction Prices of California Bartlett Pears and Deviations Therefrom, By Weeks or Groups of Weeks, 1916-1940

\begin{tabular}{|c|c|c|c|c|c|c|c|}
\hline \multirow[b]{2}{*}{ Year } & \multirow[b]{2}{*}{$\begin{array}{l}\text { Season's } \\
\text { average }\end{array}$} & \multicolumn{6}{|c|}{ Deviations from season's average* } \\
\hline & & $\begin{array}{c}\text { Through } \\
\text { second } \\
\text { week }\end{array}$ & $\begin{array}{l}\text { Third and } \\
\text { fourth } \\
\text { weeks }\end{array}$ & $\begin{array}{l}\text { Fifth } \\
\text { week }\end{array}$ & $\begin{array}{l}\text { Through } \\
\text { fifth } \\
\text { week }\end{array}$ & $\begin{array}{c}\text { Sixth- } \\
\text { eighth } \\
\text { week }\end{array}$ & $\begin{array}{l}\text { Ninth- } \\
\text { eleventh } \\
\text { week }\end{array}$ \\
\hline & $\begin{array}{l}\text { dollars } \\
\text { per box }\end{array}$ & $\begin{array}{l}\text { dollars } \\
\text { per box }\end{array}$ & $\begin{array}{l}\text { dollars } \\
\text { per box }\end{array}$ & $\begin{array}{l}\text { dollars } \\
\text { per box }\end{array}$ & $\begin{array}{l}\text { dollars } \\
\text { per box }\end{array}$ & $\begin{array}{l}\text { dollars } \\
\text { per box }\end{array}$ & $\begin{array}{l}\text { dollars } \\
\text { per box }\end{array}$ \\
\hline 1916 & 2.63 & -0.24 & -0.39 & 0.34 & -0.19 & 0.24 & $\ldots$ \\
\hline 1917. & 2.79 & 0.17 & 0.02 & 0.23 & 0.11 & -0.15 & -0.18 \\
\hline 1918. & 3.05 & 1.29 & 0.27 & -0.23 & 0.35 & -0.67 & 1.23 \\
\hline 1919. & 3.95 & 0.27 & -0.22 & -0.14 & -0.09 & -0.24 & -0.97 \\
\hline 1920. & 4.51 & 0.01 & -0.94 & 0.42 & -0.43 & 1.20 & 0.53 \\
\hline 1921. & 3.55 & 1.10 & 0.20 & -0.46 & 0.18 & -0.47 & 1.38 \\
\hline 1922. & 2.78 & 0.98 & -0.32 & 0.49 & 0.18 & -0.32 & -0.03 \\
\hline 1923. & 3.04 & 0.20 & -0.53 & -0.39 & -0.30 & 0.42 & 0.81 \\
\hline 1924. & 3.91 & 0.06 & -0.18 & 0.28 & 0 & -0.12 & 0.21 \\
\hline 1925 & 2.83 & 0.76 & -0.31 & -0.57 & -0.07 & -0.05 & 0.38 \\
\hline 1926. & 2.70 & 0.26 & -0.38 & -0.05 & -0.08 & -0.04 & 0.12 \\
\hline 1927 & 3.37 & 0.54 & 0.59 & 0.22 & 0.47 & -0.61 & -0.05 \\
\hline 1928. & 2.94 & 0.26 & -0.72 & -0.69 & -0.43 & 0.43 & 0.46 \\
\hline 1929. & 3.71 & 0.73 & -0.33 & -0.46 & -0.10 & 0.06 & 0.20 \\
\hline 1930 . & 2.38 & 0.97 & -0.26 & -0.07 & 0.18 & -0.27 & 0.06 \\
\hline 1931. & 2.67 & 0.15 & 0.32 & -0.03 & 0.18 & -0.27 & -0.16 \\
\hline 1932. & 2.01 & 0.68 & -0.14 & -0.43 & -0.01 & -0.15 & 0.15 \\
\hline 1933. & 2.31 & 0.18 & -0.07 & 0.07 & 0.03 & 0.09 & -0.12 \\
\hline 1934. & 2.56 & 0.03 & -0.18 & -0.13 & -0.11 & 0.02 & 0.09 \\
\hline 1935. & 2.37 & 0.61 & -0.09 & 0.06 & 0.09 & -0.06 & -0.18 \\
\hline 1936. & 2.35 & 0.20 & -0.33 & -0.26 & -0.18 & 0.13 & 0.04 \\
\hline 1937. & 2.49 & 0.36 & -0.18 & -0.08 & 0.01 & 0.04 & -0.17 \\
\hline 1938. & 1.96 & 0.12 & -0.13 & -0.13 & -0.06 & -0.10 & 0.07 \\
\hline 1939. & 2.56 & 0.09 & -0.15 & 0.07 & -0.02 & 0.03 & 0.07 \\
\hline 1940. & 2.36 & 0.44 & -0.04 & -0.06 & 0.07 & -0.11 & 0.01 \\
\hline
\end{tabular}

* Based on weighted-average price for week or group of weeks.

Source of data:

Based on data given in table 13. 


\section{TABLE 17}

Relative Average Weekly Volume of New York Auction Sales of California Bartlett Pears by Groups of Weeks as Percentages of Season's Total Sales, 1916-1940

\begin{tabular}{|c|c|c|c|c|c|c|}
\hline \multirow{2}{*}{ Year } & \multicolumn{6}{|c|}{ Averages for weeks } \\
\hline & $\begin{array}{c}\text { First } \\
\text { and second }\end{array}$ & $\begin{array}{c}\text { Third } \\
\text { and fourth }\end{array}$ & Fifth & $\begin{array}{l}\text { First- } \\
\text { fifth }\end{array}$ & $\begin{array}{l}\text { Sixth- } \\
\text { eighth }\end{array}$ & $\begin{array}{l}\text { Ninth- } \\
\text { eleventh }\end{array}$ \\
\hline 1916 . & $\begin{array}{c}\text { per cent } \\
5.8\end{array}$ & $\begin{array}{c}\text { per cent } \\
15.6\end{array}$ & $\begin{array}{c}\text { per cent } \\
13.3\end{array}$ & $\begin{array}{c}\text { per cent } \\
11.3\end{array}$ & $\begin{array}{c}\text { per cent } \\
12.5\end{array}$ & $\begin{array}{c}\text { per cent } \\
0.0\end{array}$ \\
\hline $1917 \ldots \ldots \ldots \ldots$ & 7.8 & 14.0 & 12.9 & 11.3 & 10.7 & 3.2 \\
\hline $1918 \ldots \ldots \ldots \ldots$ & 5.8 & 12.4 & 17.0 & 10.7 & 13.1 & 1.9 \\
\hline $1919 \ldots \ldots \ldots$ & 6.6 & 15.0 & 14.2 & 11.5 & 9.8 & 4.0 \\
\hline $1920 \ldots \ldots \ldots \ldots \ldots \ldots \ldots$ & 10.2 & 18.6 & 11.8 & 13.9 & 7.0 & 2.8 \\
\hline $1921 \ldots \ldots \ldots \ldots \ldots \ldots \ldots$ & 5.8 & 15.4 & 18.4 & 12.1 & 11.7 & 1.2 \\
\hline $1922 \ldots \ldots \ldots \ldots \ldots \ldots \ldots$ & 6.8 & 13.8 & 8.6 & 10.0 & 10.1 & 5.6 \\
\hline $1923 \ldots \ldots \ldots$ & 8.5 & 16.6 & 12.4 & 12.5 & 9.3 & 2.7 \\
\hline $1924 \ldots \ldots \ldots \ldots \ldots \ldots \ldots \ldots$ & 7.2 & 10.6 & 10.7 & 9.3 & 12.0 & 5.4 \\
\hline $1925 \ldots \ldots \ldots \ldots \ldots$ & 7.1 & 11.4 & 13.4 & 10.1 & 10.9 & 5.0 \\
\hline $1926 \ldots \ldots \ldots \ldots \ldots \ldots \ldots$ & 8.9 & 11.5 & 7.6 & 9.7 & 9.6 & 6.1 \\
\hline $1927 \ldots \ldots \ldots \ldots \ldots \ldots \ldots$ & 5.6 & 10.0 & 12.7 & 8.8 & 11.6 & 6.5 \\
\hline $1928 \ldots \ldots \ldots \ldots \ldots \ldots \ldots$ & 6.9 & 11.6 & 12.0 & 9.8 & 8.2 & 6.7 \\
\hline $1929 \ldots \ldots \ldots \ldots \ldots \ldots \ldots$ & 6.0 & 12.3 & 11.8 & 9.7 & 10.3 & 5.9 \\
\hline $1930 \ldots \ldots \ldots \ldots \ldots \ldots \ldots \ldots$ & 6.8 & 10.1 & 11.1 & 9.0 & 9.7 & 6.2 \\
\hline $1931 \ldots \ldots \ldots$ & 5.4 & 8.3 & 9.2 & 7.3 & 10.2 & 8.8 \\
\hline $1932 \ldots \ldots \ldots$ & 6.0 & 12.4 & 12.2 & 9.8 & 10.0 & 5.7 \\
\hline $1933 \ldots \ldots$ & 4.6 & 9.6 & 9.6 & 7.6 & 9.0 & 7.7 \\
\hline $1934 \ldots \ldots \ldots \ldots$ & 6.3 & 10.2 & 10.5 & 8.7 & 8.8 & 7.6 \\
\hline $1935 \ldots \ldots \ldots \ldots \ldots \ldots \ldots$ & 4.2 & 11.6 & 11.6 & 8.7 & 11.2 & 5.9 \\
\hline 1936. & 5.6 & 12.1 & 10.1 & 9.1 & 8.4 & 7.3 \\
\hline $1937 \ldots$ & 6.7 & 10.0 & 10.9 & 8.8 & 9.1 & 7.5 \\
\hline $1938 \ldots \ldots$ & 5.6 & 9.2 & 11.7 & 8.3 & 9.4 & 7.0 \\
\hline $1939 \ldots \ldots \ldots$ & 7.0 & 9.2 & 10.1 & 8.5 & 9.5 & 5.9 \\
\hline $1940 \ldots$ & 4.1 & 8.7 & 9.5 & 7.0 & 10.8 & 7.4 \\
\hline
\end{tabular}

Source of data:

Simple averages of relative sales for corresponding weeks computed from data in table 13 . 
TABLE 18

Weekly New York Auction Prices per Box of California

Bartlett Pears, by Sizes, 1936-1939

\begin{tabular}{|c|c|c|c|c|c|c|c|c|c|c|c|c|c|}
\hline \multirow{2}{*}{$\begin{array}{l}\text { Week } \\
\text { ending }\end{array}$} & \multicolumn{12}{|c|}{ Number of pears per box* } & \multirow[b]{2}{*}{$\begin{array}{l}\text { Average } \\
\text { of all } \\
\text { sizes }\end{array}$} \\
\hline & $\begin{array}{l}\text { Larg- } \\
\text { er- } \\
\text { than } \\
70\end{array}$ & 70 & 80 & 90 & 100 & 110 & 120 & 135 & 150 & 165 & 180 & 195 & \\
\hline 1936: & $\begin{array}{l}\text { dol- } \\
\text { lars }\end{array}$ & $\begin{array}{l}\text { dol- } \\
\text { lars }\end{array}$ & $\begin{array}{l}\text { dol- } \\
\text { lars }\end{array}$ & $\begin{array}{l}\text { dol- } \\
\text { lars }\end{array}$ & $\begin{array}{l}\text { dol- } \\
\text { lars }\end{array}$ & $\begin{array}{l}\text { dol- } \\
\text { lars }\end{array}$ & $\begin{array}{l}\text { dol- } \\
\text { lars }\end{array}$ & $\begin{array}{l}\text { dol- } \\
\text { lars }\end{array}$ & $\begin{array}{l}\text { dol- } \\
\text { lars }\end{array}$ & $\begin{array}{l}\text { dol- } \\
\text { lars }\end{array}$ & $\begin{array}{l}\text { dol- } \\
\text { lars }\end{array}$ & $\begin{array}{l}\text { dol- } \\
\text { lars }\end{array}$ & $\begin{array}{l}\text { dol- } \\
\text { lars }\end{array}$ \\
\hline July 10 & $\ldots$ & $\ldots$ & & & & 3.45 & 3.97 & 3.82 & 3.44 & 3.34 & 3.29 & $\ldots$ & 3.34 \\
\hline July 17 & $\ldots$ & $\ldots$ & $\ldots$ & $\ldots$ & 2.37 & 2.81 & 2.80 & 2.57 & 2.39 & 2.36 & 2.38 & & 2.39 \\
\hline July 24 & $\ldots$ & $\ldots$ & & 1.77 & 2.40 & 2.47 & 2.29 & 2.23 & 2.21 & 2.23 & 2.28 & & 2.24 \\
\hline July 31 & $\ldots$ & $\ldots$ & 1.70 & 1.80 & 1.88 & 1.90 & 1.84 & 1.82 & 1.84 & 1.87 & 1.93 & & 1.87 \\
\hline Aug. 7 & $\ldots$ & 2.30 & 2.20 & 2.03 & 2.09 & 2.04 & 2.00 & 1.99 & 2.09 & 2.11 & 2.19 & & 2.09 \\
\hline Aug. 14 & 1.60 & 2.22 & 2.15 & 2.31 & 2.22 & 2.04 & 2.22 & 2.29 & 2.39 & 2.43 & 2.52 & $\ldots$ & 2.39 \\
\hline Aug. 21 & & 2.23 & 2.32 & 2.38 & 2.28 & 2.28 & 2.35 & 2.45 & 2.61 & 2.67 & 2.78 & & 2.58 \\
\hline Aug. 28 & 2.10 & 2.30 & 2.38 & 2.24 & 2.21 & 2.22 & 2.26 & 2.36 & 2.51 & 2.63 & 2.63 & & 2.49 \\
\hline Sept. 4 & 1.86 & 2.05 & 2.04 & 2.06 & 1.99 & 1.98 & 2.06 & 2.20 & 2.36 & 2.43 & 2.42 & & 2.28 \\
\hline Sept. 11 & 1.92 & 2.07 & 2.21 & 2.24 & 2.18 & 2.19 & 2.24 & 2.35 & 2.51 & 2.60 & 2.62 & & 2.44 \\
\hline Sept. 18 & 1.90 & 2.07 & 2.14 & 2.17 & 2.17 & 2.20 & 2.31 & 2.43 & 2.62 & 2.71 & 2.73 & & 2.51 \\
\hline Sept. 25 & 2.38 & 2.42 & 2.45 & 2.50 & 2.50 & 2.50 & 2.56 & 2.73 & 2.91 & 3.00 & 3.01 & & 2.81 \\
\hline Oct. 2 & 2.65 & 2.88 & 2.83 & 2.83 & 2.85 & 2.84 & 2.86 & 2.97 & 3.09 & 3.13 & 3.09 & $\ldots$ & 3.01 \\
\hline Oct. 9 & $\ldots$ & 2.78 & 3.05 & 3.02 & 3.03 & 2.95 & 2.96 & 3.01 & 3.13 & 3.12 & 3.07 & $\ldots$ & 3.06 \\
\hline Oct. 16 & $\ldots$ & 2.89 & 2.80 & 2.86 & 2.85 & 2.81 & 2.70 & 2.57 & 2.64 & 2.66 & 2.67 & $\ldots$ & 2.64 \\
\hline Season & 2.04 & 2.29 & 2.29 & 2.29 & 2.22 & 2.21 & 2.22 & 2.30 & 2.36 & 2.36 & 2.42 & $\ldots$ & 2.34 \\
\hline \multicolumn{14}{|l|}{ 1937: } \\
\hline July 24 & & & & 2.47 & 2.80 & 3.43 & 3.53 & 3.33 & 3.38 & 3.43 & 3.56 & & 3.43 \\
\hline July 31 & & & & 2.70 & 2.56 & 2.48 & 2.42 & 2.34 & 2.44 & 2.49 & 2.63 & & 2.47 \\
\hline Aug. 7 & & & & 2.66 & 2.26 & 2.20 & 2.14 & 2.20 & 2.37 & 2.48 & 2.69 & & 2.36 \\
\hline Aug. 14 & & 1.70 & 1.99 & 2.13 & 2.04 & 2.01 & 2.06 & 2.15 & 2.35 & 2.48 & 2.69 & & 2.29 \\
\hline Aug. 21 & $\ldots$ & 2.05 & 2.11 & 2.21 & 2.16 & 2.14 & 2.21 & 2.34 & 2.51 & 2.58 & 2.65 & $\ldots$ & 2.42 \\
\hline Aug. 28 & $\ldots$ & 2.52 & 2.27 & 2.25 & 2.18 & 2.18 & 2.24 & 2.34 & 2.48 & 2.55 & 2.63 & $\ldots$ & 2.43 \\
\hline Sept. 4 & 1.94 & 2.04 & 2.17 & 2.20 & 2.21 & 2.25 & 2.36 & 2.50 & 2.67 & 2.74 & 2.79 & $\ldots$ & 2.56 \\
\hline Sept. 11 & 2.15 & 2.36 & 2.38 & 2.33 & 2.35 & 2.39 & 2.49 & 2.59 & 2.75 & 2.82 & 2.85 & $\ldots$ & 2.67 \\
\hline Sept. 18 & 2.12 & 2.19 & 2.19 & 2.13 & 2.17 & 2.22 & 2.31 & 2.40 & 2.52 & 2.60 & 2.62 & $\ldots$ & 2.45 \\
\hline Sept. 25 & 2.03 & 2.03 & 2.12 & 2.11 & 2.09 & 2.10 & 2.16 & 2.24 & 2.33 & 2.34 & 2.31 & $\ldots$ & 2.26 \\
\hline Oct. 2 & 2.30 & 2.20 & 2.08 & 2.00 & 2.00 & 2.02 & 2.11 & 2.24 & 2.36 & 2.37 & 2.30 & $\ldots$ & 2.25 \\
\hline Oct. 9 & 2.55 & 3.03 & 2.83 & 2.81 & 2.77 & 2.69 & 2.78 & 2.89 & 3.03 & 3.01 & 2.88 & $\ldots$ & 2.89 \\
\hline Oct. 16 & 2.69 & 2.75 & 2.84 & 2.87 & 2.90 & 2.91 & 2.96 & 3.06 & 3.17 & 3.03 & 2.88 & & 2.97 \\
\hline Oct. 23 & $\ldots$ & 2.56 & 2.57 & 2.52 & 2.52 & 2.55 & 2.63 & 2.71 & 2.90 & 2.90 & 2.98 & & 2.70 \\
\hline Oct. 30 & 3.40 & 2.85 & 2.93 & 2.95 & 2.96 & 2.88 & 3.05 & 3.19 & 3.32 & 3.29 & 3.23 & & 3.11 \\
\hline Season & 2.16 & 2.38 & 2.28 & 2.25 & 2.23 & 2.24 & 2.30 & 2.39 & 2.53 & 2.63 & 2.72 & .. & 2.49 \\
\hline \multicolumn{14}{|l|}{ 1938: } \\
\hline July 23 & $\ldots$ & & & & 2.35 & 2.54 & 2.86 & 3.26 & 3.11 & 2.83 & 2.56 & 2.25 & 2.51 \\
\hline July 30 & $\ldots$ & $\ldots$ & 1.00 & 1.00 & 1.00 & 2.14 & 3.06 & 2.69 & 2.21 & 2.00 & 1.88 & 1.77 & 1.95 \\
\hline Aug. 6 & $\ldots$ & & & & 2.99 & 2.66 & 2.63 & 2.13 & 1.89 & 1.81 & 1.79 & 1.77 & 1.84 \\
\hline Aug. 13 & $\ldots$ & . & & 2.75 & 2.56 & 2.48 & 2.20 & 1.88 & 1.80 & 1.79 & 1.84 & 1.84 & 1.83 \\
\hline Aug. 20 & $\cdots$ & $\cdots$ & & 2.02 & 2.04 & 2.17 & 1.98 & 1.80 & 1.81 & 1.81 & 1.85 & 1.84 & 1.83 \\
\hline Aug. 27 & $\ldots$ & $\ldots$ & 2.17 & 2.13 & 2.11 & 1.87 & 1.75 & 1.71 & 1.73 & 1.71 & 1.72 & 1.66 & 1.72 \\
\hline Sept. 3 & $\ldots$ & $\ldots$ & 1.77 & 1.74 & 1.74 & 1.61 & 1.66 & 1.70 & 1.78 & 1.78 & 1.80 & 1.67 & 1.74 \\
\hline Sept. 10 & $\ldots$ & 2.15 & 2.17 & 2.31 & 2.16 & 2.09 & 2.15 & 2.24 & 2.37 & 2.39 & 2.45 & 2.37 & 2.32 \\
\hline Sept. 17 & 2.05 & 2.11 & 2.06 & 2.00 & 1.89 & 1.87 & 1.93 & 2.00 & 2.14 & 2.17 & 2.23 & 2.18 & 2.10 \\
\hline Sept. 24 & $\ldots$ & 1.86 & 1.91 & 1.93 & 1.89 & 1.85 & 1.88 & 1.97 & 2.08 & 2.10 & 2.12 & 2.07 & 2.03 \\
\hline Oct. 1 & 2.20 & 2.07 & 2.08 & 2.07 & 2.13 & 2.07 & 2.06 & 2.14 & 2.19 & 2.15 & 2.12 & 2.00 & 2.13 \\
\hline Oct. 8 & $\ldots$ & 3.00 & 2.50 & 2.40 & 2.31 & 2.23 & 2.21 & 2.30 & 2.38 & 2.38 & 2.39 & 2.26 & 2.34 \\
\hline Oct. 15 & 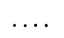 & 2.15 & 2.22 & 2.40 & 2.30 & 2.19 & 2.20 & 2.28 & 2.39 & 2.40 & 2.40 & 2.33 & 2.34 \\
\hline Oct. 22 & $\ldots$ & $\ldots$ & $\ldots$ & 2.52 & 2.46 & 2.31 & 2.27 & 2.31 & 2.39 & 2.34 & 2.25 & 2.06 & 2.31 \\
\hline Oct. 29 & $\ldots$ & $\ldots$ & $\ldots$ & $\ldots$ & 2.65 & 2.65 & 2.78 & 2.77 & 2.75 & 2.67 & 2.46 & 2.21 & 2.62 \\
\hline Season & 2.12 & 2.06 & 2.01 & 2.05 & 2.01 & 1.93 & 1.96 & 1.96 & 1.99 & 1.96 & 1.96 & 1.93 & 1.96 \\
\hline
\end{tabular}

(Table concluded on p. 306 ; footnotes at end of table.) 
TABLE 18-(Concluded)

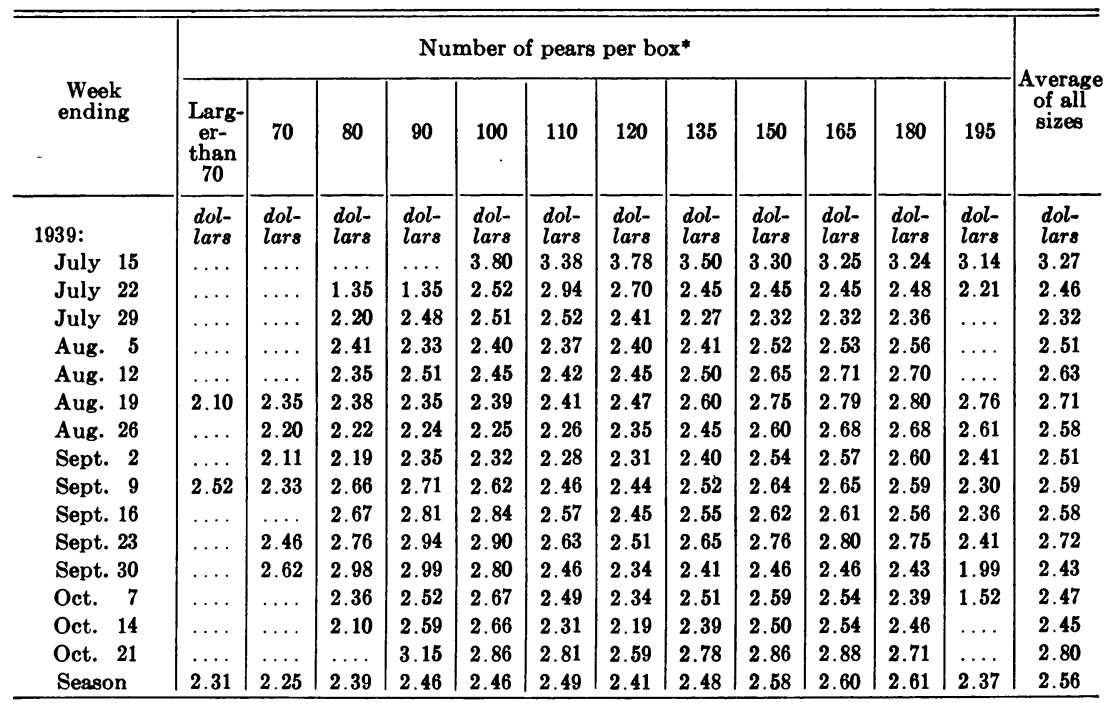

- Sizes smaller than 180 in 1936 and 1937 and smaller than 195 in 1938 and 1939 and odd sizes between 70 and 180 are not listed here separately but are included in "average of all sizes."

Sources of data:

1936 and 1937: from United States Agricultural Adjustment Administration Division of Marketing and Marketing Agreements. California Bartlett Pears, 1937. General Crops Section. San Francisco. Econ. No. 5:12-15. December, 1937. (Mimeo.)

1938: from United States Agricultural Adjustment Administration Division of Marketing and Marketing Agreements. New York Auction Market Sales and Prices of California Bartlett Pears, by Sizes, by Weeks, 1938 Season. General Crops Section. San Francisco. Econ. No. 8:1-3. February, 1939. (Mimeo.)

1939: from Studt, Ward B. California Bartlett Pears, 1939. U. S. Agricultural Adjustment Administration Division of Marketing and Marketing Agreements, General Crops Section. San Francisco. Econ. No. 12: Table 1. January, 1940. (Mimeo.) 


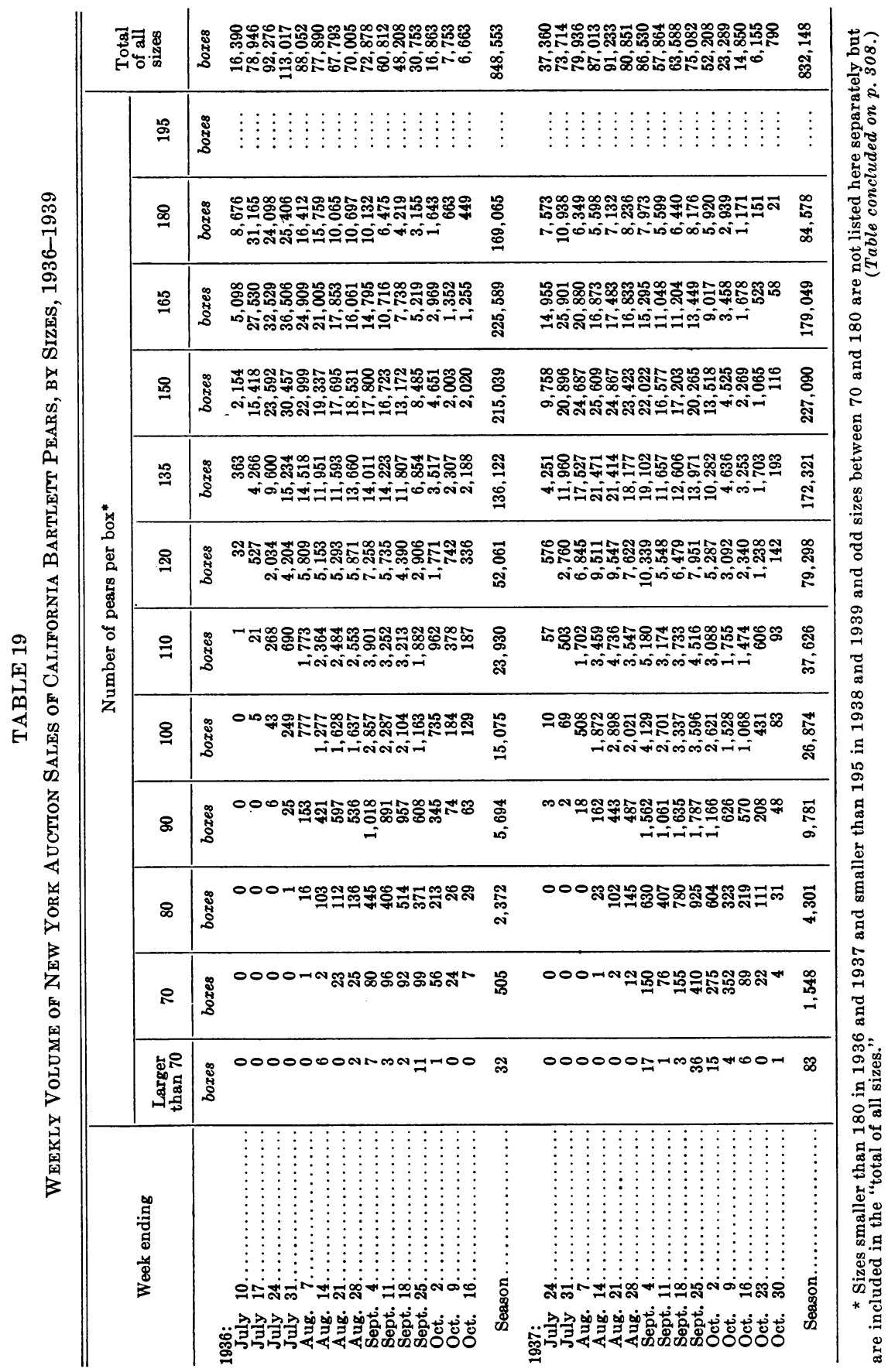




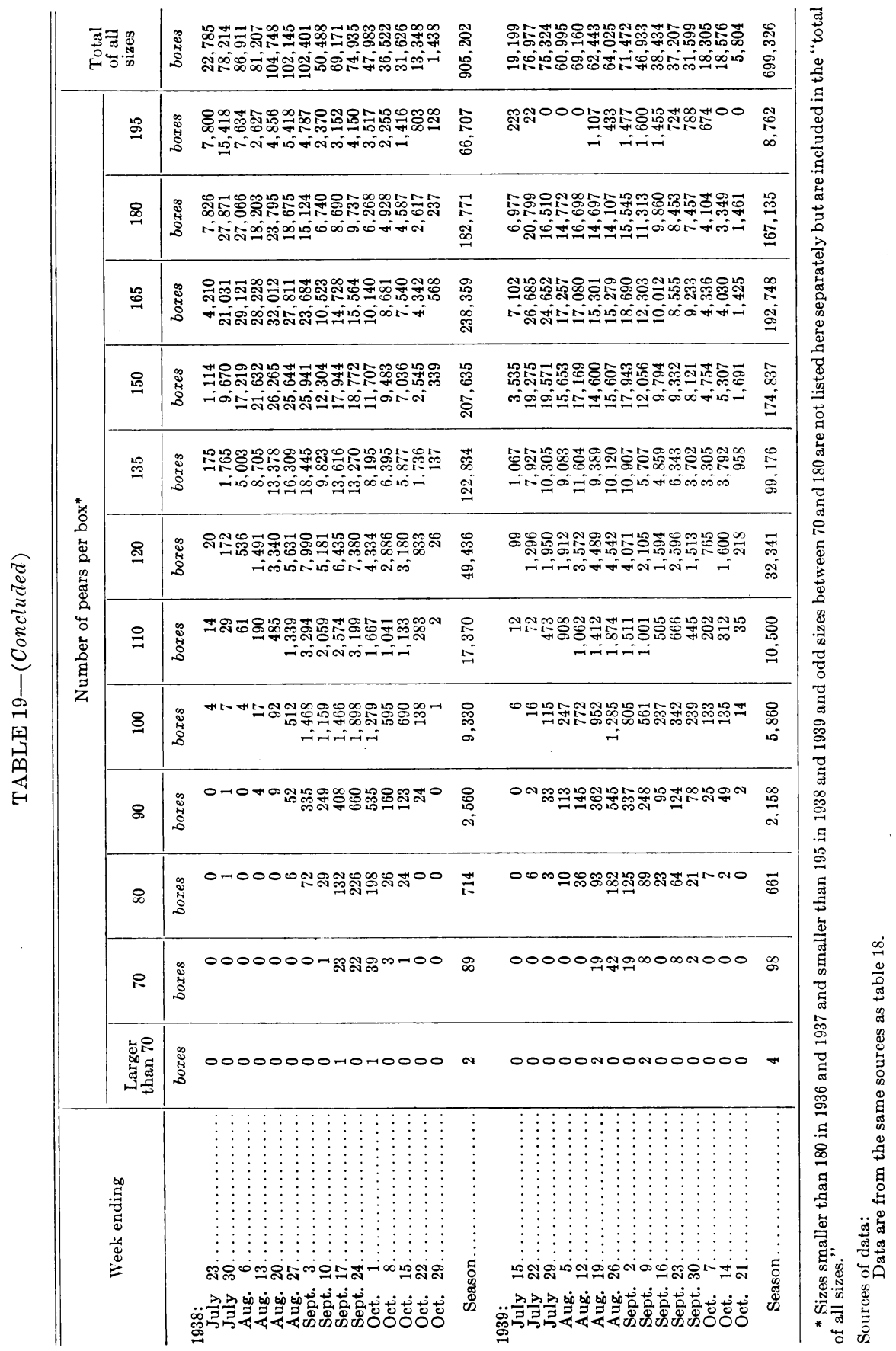




\section{TABLE 20}

Season's Average Auction Prices of California Bartlett Pears in New York, Chicago, Boston, and Philadelphia, 1920-1940

\begin{tabular}{|c|c|c|c|c|}
\hline Year & New York* & Chicago & Boston & Philadelphia \\
\hline & $\begin{array}{l}\text { dollars } \\
\text { per box }\end{array}$ & $\begin{array}{l}\text { dollars } \\
\text { per box }\end{array}$ & $\begin{array}{l}\text { dollars } \\
\text { per box }\end{array}$ & $\begin{array}{l}\text { dollars } \\
\text { per box }\end{array}$ \\
\hline $1920 \ldots$ & 4.49 & 4.40 & 4.66 & 3.94 \\
\hline 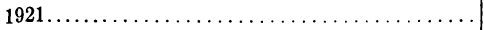 & 3.51 & 3.51 & 3.46 & 3.39 \\
\hline $1922 \ldots \ldots \ldots \ldots \ldots \ldots \ldots \ldots \ldots \ldots \ldots \ldots$ & 2.78 & 2.81 & 2.62 & 2.67 \\
\hline 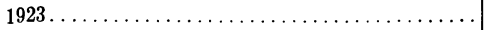 & 3.05 & 2.87 & 3.02 & 2.90 \\
\hline $1924 \ldots \ldots \ldots \ldots \ldots \ldots \ldots \ldots \ldots \ldots$ & 3.91 & 3.71 & 3.80 & 3.76 \\
\hline $1925 \ldots \ldots \ldots \ldots \ldots \ldots \ldots \ldots \ldots \ldots$ & 2.83 & 2.78 & 2.68 & 2.71 \\
\hline $1926 \ldots \ldots \ldots \ldots$ & 2.70 & 2.61 & 2.62 & 2.63 \\
\hline 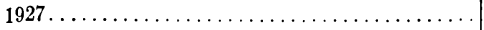 & 3.33 & 3.37 & 3.21 & 3.34 \\
\hline $1928 \ldots \ldots \ldots \ldots \ldots \ldots \ldots \ldots \ldots \ldots \ldots \ldots \ldots$ & 2.93 & 2.82 & 2.79 & 2.94 \\
\hline 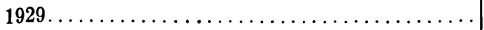 & 3.69 & 3.59 & 3.44 & 3.55 \\
\hline 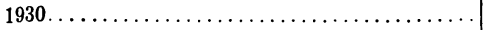 & 2.38 & 2.27 & 2.27 & 2.25 \\
\hline $1931 \ldots \ldots \ldots \ldots \ldots$ & 2.67 & 2.56 & 2.52 & 2.57 \\
\hline $1932 \ldots \ldots \ldots \ldots$ & 2.01 & 1.90 & 1.87 & 1.86 \\
\hline 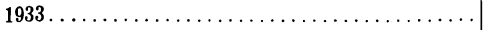 & 2.31 & 2.29 & 2.27 & 2.29 \\
\hline $1934 \ldots \ldots \ldots \ldots \ldots \ldots \ldots \ldots \ldots \ldots \ldots \ldots$ & 2.56 & 2.50 & 2.53 & 2.50 \\
\hline $1935 \ldots \ldots \ldots \ldots$ & 2.37 & 2.35 & 2.32 & 2.31 \\
\hline $1936 \ldots \ldots$ & 2.35 & 2.32 & 2.32 & 2.34 \\
\hline $1937 \ldots$ & 2.48 & 2.42 & 2.44 & 2.47 \\
\hline $1938 \ldots$ & 1.97 & 1.93 & 1.87 & 1.91 \\
\hline 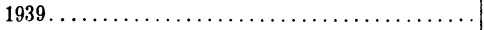 & 2.56 & 2.51 & 2.51 & 2.51 \\
\hline 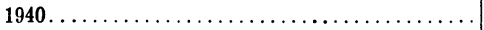 & 2.36 & 2.33 & 2.35 & 2.31 \\
\hline
\end{tabular}

* Prices given in this table for New York in some years are slightly different from those given in table 13 because different agencies compiled the data and the weekly data in table 13 for some years are slightly less complete than the season's total as given above.

\section{Sources of data:}

The basic data on daily auction sales and prices are published in daily auction reports for each of the cities given, from which sources most of the data in this table were originally compiled by various agencies.

1920-1927: from annual data compiled by the California Fruit Exchange, except Boston in 1926: from Daily Fruit Auction Reports by Samuel J. Shallow Co., New England Distributors, Boston, Mass. (Mimeo.)

1928-1931: from California Pear Deals of California Federal-State Market News Service, annual issues, except Boston in 1928: from Daily Fruit Auction Reports, by Samuel J. Shallow Co., New England Distributors, Boston, Mass. (Mimeo.)

1932-1940: from same sources as table 21. 


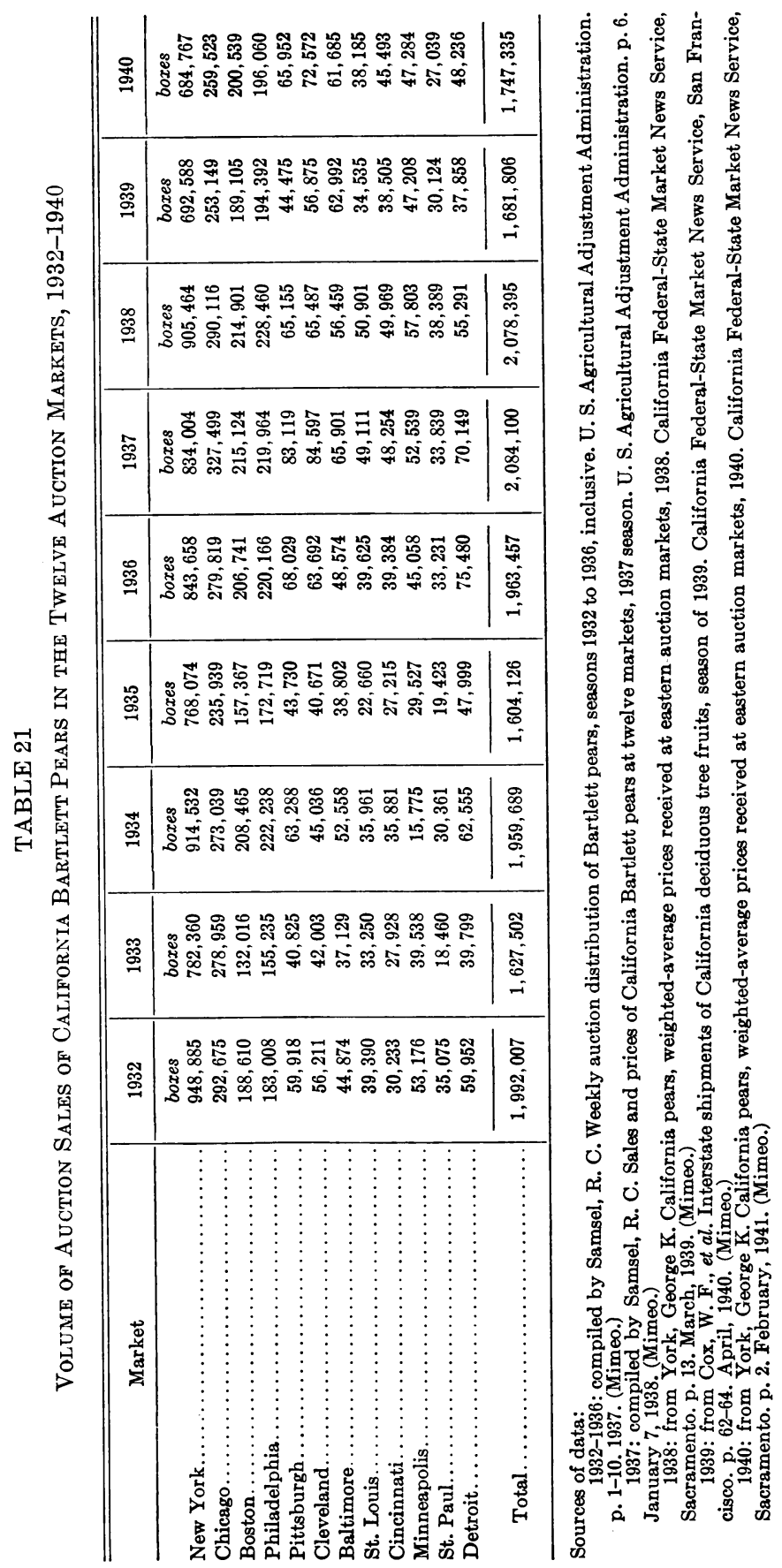


Jan., 1942] Hoos-Shear: Auction Prices and Supplies of Bartlett Pears

TABLE 22

Weekly* Auction Prices per Box of California Bartlett Pears on Eight Markets, 1935-1940

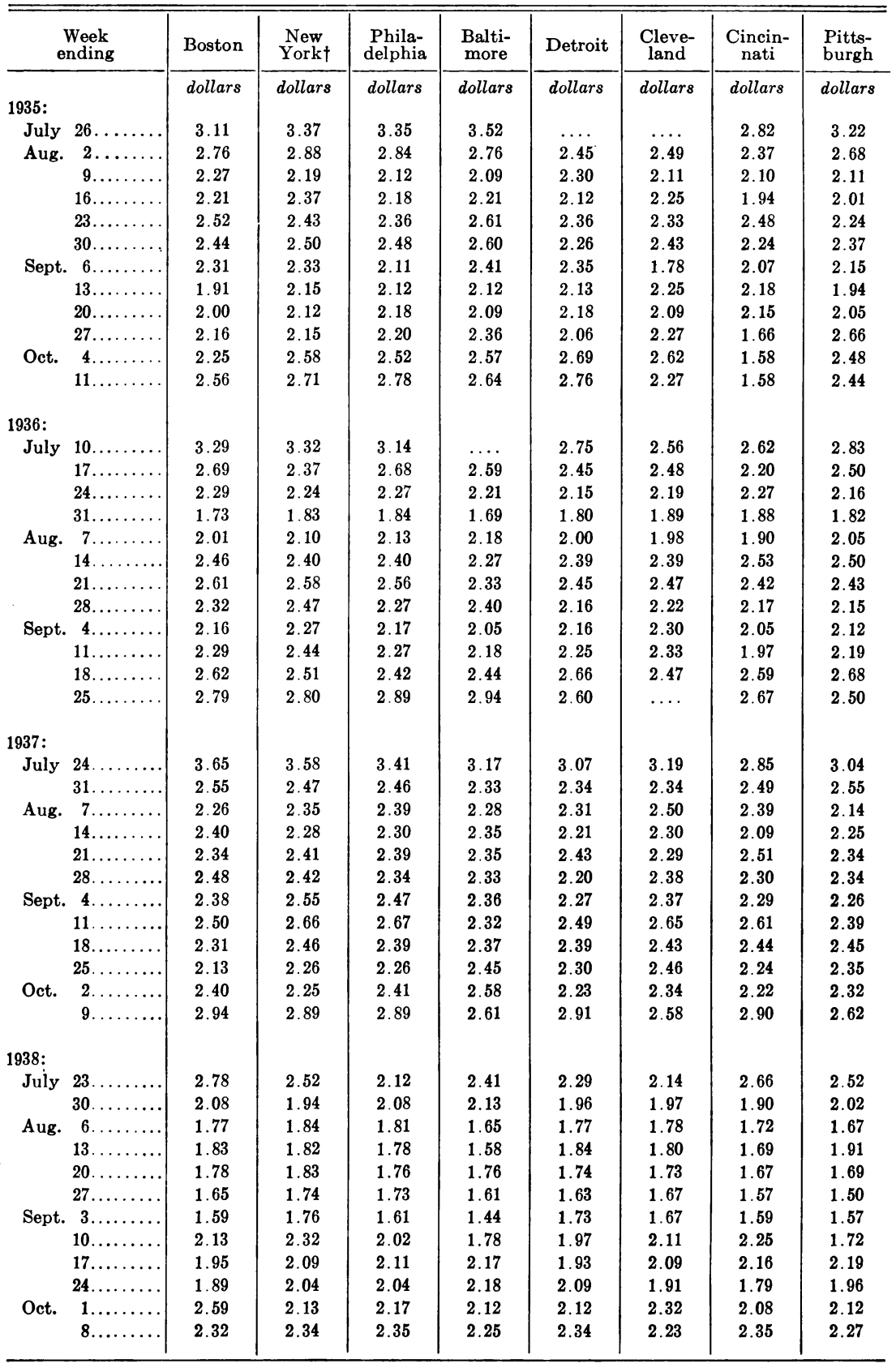

* For footnotes see p. 312 . 
TABLE 22-(Conciuded)

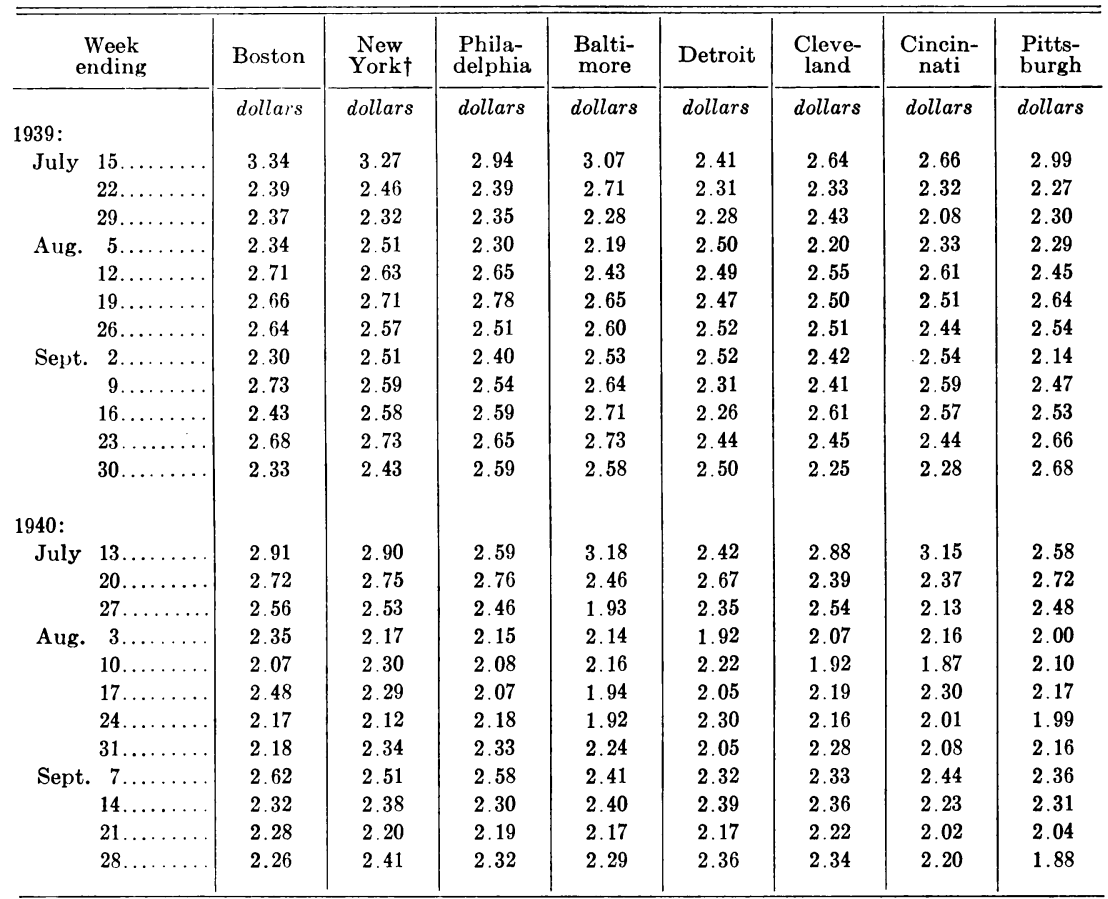

* Does not include all the weeks of the season but only the twelve important sales weeks designated as weeks 1-12 in table 13.

$\dagger$ Data for New York in 1935, 1936, and 1938 do not always check with data in table 13 because different agencies compiled the data.

Sources of data:

Data from same sources as table 21. 
TABLE 23

Analysis of Variance of Weekly Prices of California Bartlett Pears on Two Groups of Four Auction Markets, 1935-1938

\begin{tabular}{|c|c|c|c|c|c|c|}
\hline & \multicolumn{3}{|c|}{$\begin{array}{l}\text { Boston, New York, } \\
\text { Philadelphia, and Baltimore }\end{array}$} & \multicolumn{3}{|c|}{$\begin{array}{c}\text { Detroit, Cleveland, } \\
\text { Cincinnati, and Pittsburgh }\end{array}$} \\
\hline & $\begin{array}{l}\text { Degrees } \\
\text { of } \\
\text { freedom }\end{array}$ & $\begin{array}{l}\text { Sum of } \\
\text { squares }\end{array}$ & $\begin{array}{l}\text { Mean } \\
\text { square }\end{array}$ & $\begin{array}{l}\text { Degrees } \\
\text { of } \\
\text { freedom }\end{array}$ & $\begin{array}{l}\text { Sum of } \\
\text { squares }\end{array}$ & $\begin{array}{l}\text { Mean } \\
\text { square }\end{array}$ \\
\hline & \multicolumn{6}{|c|}{1935} \\
\hline $\begin{array}{l}\text { Source of variation: } \\
\text { Total. } \ldots \ldots \ldots \ldots \ldots \ldots \ldots \ldots \\
\text { Between means of markets } \ldots \ldots \ldots \ldots \\
\text { Between means of weeks } \ldots \ldots \ldots \ldots \ldots \\
\text { Remainder, interaction } \ldots \ldots \ldots \ldots \ldots\end{array}$ & $\begin{array}{r}43 \\
3 \\
10 \\
30\end{array}$ & $\begin{array}{l}2.6345 \\
0.0689 \\
2.3025 \\
0.2631\end{array}$ & $\begin{array}{l}\ldots \ldots \\
0.0230 \\
0.2302 \\
0.0088\end{array}$ & $\begin{array}{r}43 \\
3 \\
10 \\
30\end{array}$ & $\begin{array}{l}3.2285 \\
0.5924 \\
0.7437 \\
1.8924\end{array}$ & $\begin{array}{l}\ldots \ldots \\
0.1975 \\
0.0744 \\
0.0631\end{array}$ \\
\hline \multirow[t]{2}{*}{ Ratio of variance $\ldots \ldots \ldots \ldots \ldots \ldots$} & \multicolumn{3}{|c|}{$F=\frac{0.0230}{0.0088}=2.61^{*}$} & \multicolumn{3}{|c|}{$F=\frac{0.1975}{0.0631}=3.13^{*}$} \\
\hline & & & & & & \\
\hline $\begin{array}{l}\text { Source of variation: } \\
\text { Total . } \ldots \ldots \ldots \ldots \ldots \ldots \ldots \ldots \\
\text { Between means of markets } \ldots \ldots \ldots \ldots \\
\text { Between means of weeks } \ldots \ldots \ldots \ldots \ldots \\
\text { Remainder, interaction } \ldots \ldots \ldots \ldots \ldots\end{array}$ & $\begin{array}{r}43 \\
3 \\
10 \\
30\end{array}$ & $\begin{array}{l}3.5007 \\
0.0321 \\
3.2077 \\
0.2609\end{array}$ & $\begin{array}{l}\ldots \ldots \\
0.0107 \\
0.3208 \\
0.0087\end{array}$ & $\begin{array}{r}39 \\
3 \\
9 \\
27\end{array}$ & $\begin{array}{l}2.1586 \\
0.0317 \\
1.9213 \\
0.2056\end{array}$ & $\begin{array}{l}\ldots \ldots \\
0.0106 \\
0.2135 \\
0.0076\end{array}$ \\
\hline \multirow[t]{2}{*}{ 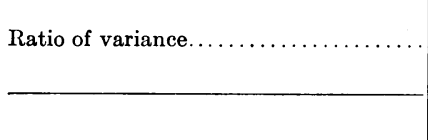 } & \multicolumn{3}{|c|}{$F=\frac{0.0107}{0.0087}=1.23^{*}$} & \multicolumn{3}{|c|}{$F=\frac{0.0106}{0.0076}=1.39 \dagger$} \\
\hline & \multicolumn{6}{|c|}{1937} \\
\hline \multirow[t]{2}{*}{ 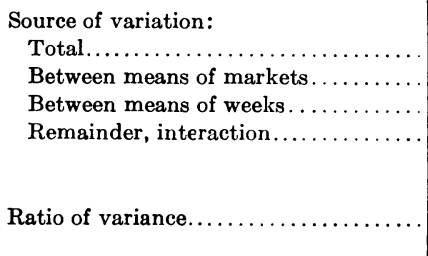 } & $\begin{array}{r}43 \\
3 \\
10 \\
30\end{array}$ & $\begin{array}{l}1.2616 \\
0.0265 \\
0.9086 \\
0.3265\end{array}$ & $\begin{array}{l}\ldots \ldots \\
0.0088 \\
0.0909 \\
0.0109\end{array}$ & $\begin{array}{r}43 \\
3 \\
10 \\
30\end{array}$ & $\begin{array}{l}1.2408 \\
0.0255 \\
0.8846 \\
0.3307\end{array}$ & $\begin{array}{l}\ldots \ldots \\
0.0085 \\
0.0885 \\
0.0110\end{array}$ \\
\hline & \multicolumn{3}{|c|}{$F=\frac{0.0109}{0.0088}=1.24 \ddagger$} & \multicolumn{3}{|c|}{$F=\frac{0.0110}{0.0085}=1.29 t$} \\
\hline & & & & & & \\
\hline $\begin{array}{l}\text { Source of variation: } \\
\text { Total } \ldots \ldots \ldots \ldots \ldots \ldots \ldots \ldots \ldots \\
\text { Between means of markets } \ldots \ldots \ldots \ldots \\
\text { Between means of weeks } \ldots \ldots \ldots \ldots \ldots \\
\text { Remainder, interaction } \ldots \ldots \ldots \ldots \ldots\end{array}$ & $\begin{array}{r}43 \\
3 \\
10 \\
30\end{array}$ & $\begin{array}{l}2.7989 \\
0.0701 \\
2.2704 \\
0.4584\end{array}$ & $\begin{array}{l}\cdots \cdots \\
0.0234 \\
0.2270 \\
0.0153\end{array}$ & $\begin{array}{r}43 \\
3 \\
10 \\
30\end{array}$ & $\begin{array}{l}2.4215 \\
0.0254 \\
2.0599 \\
0.3362\end{array}$ & $\begin{array}{l}\ldots \ldots \\
0.0085 \\
0.2060 \\
0.0112\end{array}$ \\
\hline Ratio of variance $\ldots \ldots \ldots \ldots \ldots \ldots$ & $F=\frac{0}{0}$ & $\frac{0234}{0153}=1$ & & $F=\frac{0}{0}$ & $\frac{0112}{0085}=1$ & \\
\hline
\end{tabular}

* $\mathrm{F}=2.92$ at the 5 per cent point, and $\mathrm{F} \quad 4.51$ at the 1 per cent point, for ( 3 corresponding to the greater mean square) and 30 degrees of freedom.

$\dagger \mathrm{F}=2.96$ at the 5 per cent point, and $\mathrm{F}=4.60$ at the 1 per cent point, for 3 (corresponding to the greater mean square) and 27 degrees of freedom.

$\ddagger=8.62$ at the 5 per cent point, and $F=26.50$ at the 1 per cent point, for 30 (corresponding to the greater mean square) and 3 degrees of freedom.

Source of data:

Based upon data in table 22 . 


\section{TABLE 24}

Freight and Refrigeration Rates on Deciduous Fruits from California Shipping Points to Twelve Markets as of June, 1940

\begin{tabular}{|c|c|c|c|c|c|c|c|c|c|}
\hline \multirow{3}{*}{ Destination } & \multirow{2}{*}{\multicolumn{2}{|c|}{$\frac{\text { Freight rates }}{\underbrace{\text { Minimum }}_{\text {carload }}}$}} & \multicolumn{7}{|c|}{ Refrigeration charges under different icing rules* } \\
\hline & & & \multirow{2}{*}{$\begin{array}{l}\text { Stan- } \\
\text { dard }\end{array}$} & \multirow{2}{*}{$\underset{240}{\text { Rule }}$} & \multicolumn{2}{|c|}{ Rule 247} & \multicolumn{3}{|c|}{ Rule 254} \\
\hline & $\begin{array}{l}27,500 \\
\text { pounds }\end{array}$ & $\begin{array}{l}34,000 \\
\text { pounds }\end{array}$ & & & $\begin{array}{l}\text { Iced by } \\
\text { shipper }\end{array}$ & $\begin{array}{c}\text { Iced by } \\
\text { carrier }\end{array}$ & $\underset{\text { re-iced }}{\text { Not }}$ & $\begin{array}{c}\text { Re-iced } \\
\text { once }\end{array}$ & $\begin{array}{c}\text { Re-iced } \\
\text { twice }\end{array}$ \\
\hline Boston. & \begin{tabular}{|} 
dollars \\
per 100 \\
pounds \\
1.63
\end{tabular} & $\begin{array}{c}\text { dollars } \\
\text { per } 100 \\
\text { pounds } \\
1.50\end{array}$ & $\begin{array}{c}\text { dollars } \\
\text { per } \\
\text { carload } \\
97.50\end{array}$ & $\begin{array}{c}\text { dollars } \\
\text { per } \\
\text { carload } \\
16.00\end{array}$ & $\begin{array}{c}\text { dollars } \\
\text { per } \\
\text { carload } \\
31.00\end{array}$ & $\begin{array}{c}\text { dollars } \\
\text { per } \\
\text { carload } \\
50.00\end{array}$ & $\begin{array}{c}\text { dollars } \\
\text { per } \\
\text { carload } \\
41.50\end{array}$ & $\begin{array}{c}\text { dollars } \\
\text { per } \\
\text { carload } \\
55.00\end{array}$ & $\begin{array}{c}\text { dollars } \\
\text { per } \\
\text { carload } \\
75.00\end{array}$ \\
\hline New York.... & 1.63 & 1.50 & 95.00 & 15.00 & 30.00 & 49.00 & 40.50 & 54.00 & 74.00 \\
\hline Philadelphia. & 1.63 & 1.50 & 95.00 & 15.00 & 30.00 & 49.00 & 40.50 & 54.00 & 74.00 \\
\hline Baltimore. . & 1.63 & 1.50 & 95.00 & 15.00 & 30.00 & 49.00 & 40.50 & 54.00 & 74.00 \\
\hline Pittsburgh. & 1.63 & 1.50 & 85.00 & 14.00 & 29.00 & 48.00 & 39.50 & 53.00 & 73.00 \\
\hline Cincinnati. & 1.63 & 1.50 & 85.00 & 14.00 & 29.00 & 48.00 & 39.50 & 53.00 & 73.00 \\
\hline Detroit..... & 1.63 & 1.50 & 85.00 & 14.00 & 29.00 & 48.00 & 39.50 & 53.00 & 73.00 \\
\hline Cleveland.. & 1.63 & 1.50 & 85.00 & 14.00 & 29.00 & 48.00 & 39.50 & 53.00 & 73.00 \\
\hline Chicago.. & $1.63 \dagger$ & 1.50 & 79.00 & 12.00 & 27.00 & 46.00 & 37.50 & 51.00 & 70.00 \\
\hline St. Louis.. & $1.63 \dagger$ & 1.50 & 79.00 & 12.00 & 27.00 & 46.00 & 37.50 & 51.00 & 70.00 \\
\hline Minneapolis.. & $1.63 \dagger$ & 1.50 & 79.00 & 12.00 & 27.00 & 46.00 & 37.50 & 51.00 & 70.00 \\
\hline St. Paul... & $1.63 \dagger$ & 1.50 & 79.00 & 12.00 & 27.00 & 46.00 & 37.50 & 51.00 & 70.00 \\
\hline
\end{tabular}

* The different methods of refrigeration, or icing rules, for which different refrigeration rates are charged by the railroads are as follows:

Standard refrigeration (pre-iced or dry-car loaded).

Rule 240, initially iced by shipper, or if by carrier cost of ice is in addition to charges shown; not re-iced by carrier.

Rule 247, initially iced by shipper; re-iced once in transit by carrier; or initially iced by carrier; re-iced once in transit by carrier.

Rule 254, pre-iced and replenished by carrier; not re-iced; or pre-iced and replenished by carrier; reiced once in transit; or pre-iced and replenished by carrier; re-iced twice in transit.

$\dagger$ A minimum carload weight of 26,000 pounds to Chicago, St. Louis, Minneapolis, and St. Paul takes the freight rate of $\$ 1.63$ per 100 pounds.

Source of data:

California Fruit Exchange, Traffic Department Circular No. 258, Sacramento, California, p. 1-7. June 11, 1940. (Mimeo.) 
TABLE 25

New York Wholesale Prices of Fresh Oranges, Plums, Peaches, and Pears, Average July-August; and New York State Factory Wages, AVERAGE JunE-AUgust, 1924-1939

\begin{tabular}{|c|c|c|c|c|c|}
\hline \multirow{2}{*}{ Year } & Oranges & Plums & Peaches & Pears & $\begin{array}{l}\text { Wage } \\
\text { per week }\end{array}$ \\
\hline & 1 & 2 & $\boldsymbol{s}$ & 4 & $\boldsymbol{5}$ \\
\hline & $\begin{array}{l}\text { dollars per } \\
100 \text { pounds* }\end{array}$ & $\begin{array}{l}\text { dollars per } \\
100 \text { pounds }\end{array}$ & $\begin{array}{l}\text { dollars per } \\
100 \text { pounds* }\end{array}$ & $\begin{array}{l}\text { dollars per } \\
100 \text { pounds* }\end{array}$ & dollars \\
\hline $1924 \ldots$ & 6.63 & 8.86 & 4.96 & 8.04 & 27.22 \\
\hline $1925 \ldots \ldots \ldots \ldots$ & 9.19 & 7.27 & 4.87 & 5.67 & 28.03 \\
\hline$\ldots \ldots \ldots \ldots \ldots \ldots$ & 7.20 & 6.68 & 3.35 & 5.44 & 28.89 \\
\hline $1927 \ldots \ldots \ldots \ldots$ & 8.63 & 8.09 & 5.70 & 7.15 & 29.14 \\
\hline 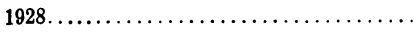 & 10.71 & 7.41 & 4.13 & 5.81 & 29.34 \\
\hline 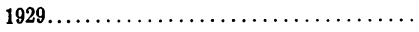 & 6.36 & 10.86 & 6.70 & 7.60 & 29.97 \\
\hline $1930 \ldots \ldots \ldots \ldots$ & 10.50 & 6.23 & 6.35 & 5.06 & 28.68 \\
\hline $1931 \ldots \ldots \ldots$ & 5.81 & 6.86 & 3.91 & 5.40 & 26.35 \\
\hline $1932 \ldots \ldots \ldots \ldots$ & 4.71 & 6.09 & 4.57 & 4.06 & 21.98 \\
\hline 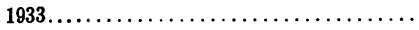 & 4.60 & 5.86 & 3.57 & 4.78 & 22.26 \\
\hline$\ldots \ldots \ldots \ldots \ldots \ldots$ & 5.73 & 6.36 & 4.74 & 5.04 & 23.26 \\
\hline $1935 \ldots \ldots \ldots \ldots$ & 4.96 & 7.00 & 4.61 & 4.94 & 24.16 \\
\hline $1936 \ldots \ldots \ldots \ldots$ & 5.87 & 6.36 & 5.35 & 4.56 & 25.35 \\
\hline $1937 \ldots \ldots \ldots \ldots$ & 7.67 & 7.95 & 5.35 & 4.98 & 27.97 \\
\hline $1938 \ldots \ldots \ldots \ldots$ & 4.61 & 5.70 & 4.28 & 3.70 & 26.07 \\
\hline $1939 \ldots \ldots \ldots \ldots$ & 4.59 & 6.55 & $4.04 \dagger$ & 5.12 & 27.22 \\
\hline
\end{tabular}

- Converted to dollars per 100 pounds from prices of oranges in 70-pound box; plums for 1924-1937 in 22-pound crate and for 1938-1939 in 231-pound crate; peaches in 46-pound 6-basket carrier; and pears for 1924-1932 in 48-pound box and for 1933-1939 in 50-pound box.

$\dagger$ Preliminary estimate.

\section{Sources of data:}

Cols 1,2 , and 4: New York auction prices of California Bartletts, of California plums (most important varieties), and of California Valencia oranges compiled by various agencies from the New

York Daily Fruit Reporter.
Col. 3: Theaverage wholesaleless-than-carload-lot prices of all peachessold on the New York market in 6-basket carriers as compiled by the United States Department of Agriculture, Agricultural Statistics, and current mimeographed reports of the United States Bureau of Agricultural Economics, The Fruit Situation.

Col. 4: The New York state factory wages are simple averages of the average weekly wage for June, July, and August.

$$
\begin{aligned}
& \text { 1924-1935: from United States Bureau of Labor Statistics. Handbook of labor statistics. } \\
& \text { 1936-1939: from New York State Industrial Commissioner. Department of Labor. The }
\end{aligned}
$$
p. 931.1936 . Industrial Bulletin, April, 1941, issues. 
TABLE 26

New York Unloads* of Fresh Oranges, Peaches, Pears, and Plums, July-August, 1924-1940

\begin{tabular}{|c|c|c|c|c|}
\hline Year & Oranges & Peaches & Pears & Plums \\
\hline & tons & tons & tons & tons \\
\hline \multicolumn{5}{|l|}{ Annual: } \\
\hline $1924 \ldots \ldots \ldots \ldots$ & 21,258 & 41,830 & 18,489 & 6,582 \\
\hline 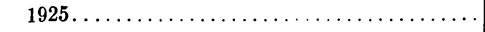 & 15,426 & 38,772 & 21,919 & 5,526 \\
\hline$\ldots \ldots \ldots \ldots \ldots \ldots \ldots \ldots$ & 24,762 & 46,516 & 29,328 & 5,742 \\
\hline $1927 \ldots \ldots \ldots \ldots \ldots \ldots \ldots \ldots \ldots \ldots \ldots$ & 22,766 & 32,500 & 17,082 & 5,758 \\
\hline $1928 \ldots \ldots \ldots \ldots$ & 18,766 & 46,820 & 20,708 & 6,000 \\
\hline $1929 \ldots \ldots$ & 35,702 & 36,990 & 13,071 & 3,504 \\
\hline 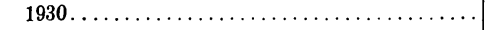 & 23,718 & 29,680 & 22,068 & 7,998 \\
\hline 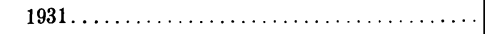 & 39,263 & 50,940 & 19,255 & 5,638 \\
\hline 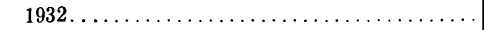 & 38,553 & 27,642 & 17,293 & 7,364 \\
\hline $1933 \ldots \ldots \ldots \ldots$ & 36,540 & 35,560 & 11,063 & 8,136 \\
\hline $1934 \ldots \ldots \ldots \ldots$ & 34,022 & 29,762 & 18,552 & 6,955 \\
\hline $1935 \ldots$ & 36,817 & 37,338 & 9,605 & 6,807 \\
\hline $1936 \ldots \ldots \ldots \ldots$ & 34,201 & 31,906 & 14,161 & 6,576 \\
\hline 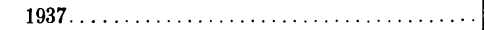 & 28,302 & 27,574 & 11,890 & 12,298 \\
\hline 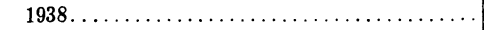 & 40,091 & 38,668 & 14,289 & 12,384 \\
\hline $1939 \ldots \ldots \ldots \ldots \ldots \ldots$ & 47,712 & 35,980 & 12,728 & 14,220 \\
\hline $1940 \ldots \ldots \ldots \ldots$ & 37,663 & 38,746 & 12,446 & 15,298 \\
\hline \multicolumn{5}{|l|}{ Averages: } \\
\hline 1924-1928. & 20,596 & 41,288 & 21,505 & 5,922 \\
\hline $1929-1933 \ldots \ldots \ldots$ & 34,755 & 36,162 & 16,550 & 6,528 \\
\hline $1934-1938 \ldots \ldots \ldots$ & 34,687 & 33,050 & 13,693 & 9,004 \\
\hline
\end{tabular}

* Includes only rail and boat unloads prior to July 15, 1928, but also includes truck unloads beginning July 15, 1928.

\section{Source of data:}

From United States Bureau of Agricultural Economics. Unloads of fruits and vegetables at New York city, annual reports. (Mimeo.) Data reported in carlot equivalents and converted to tons at various factors, according to the fruit and state of origin. 


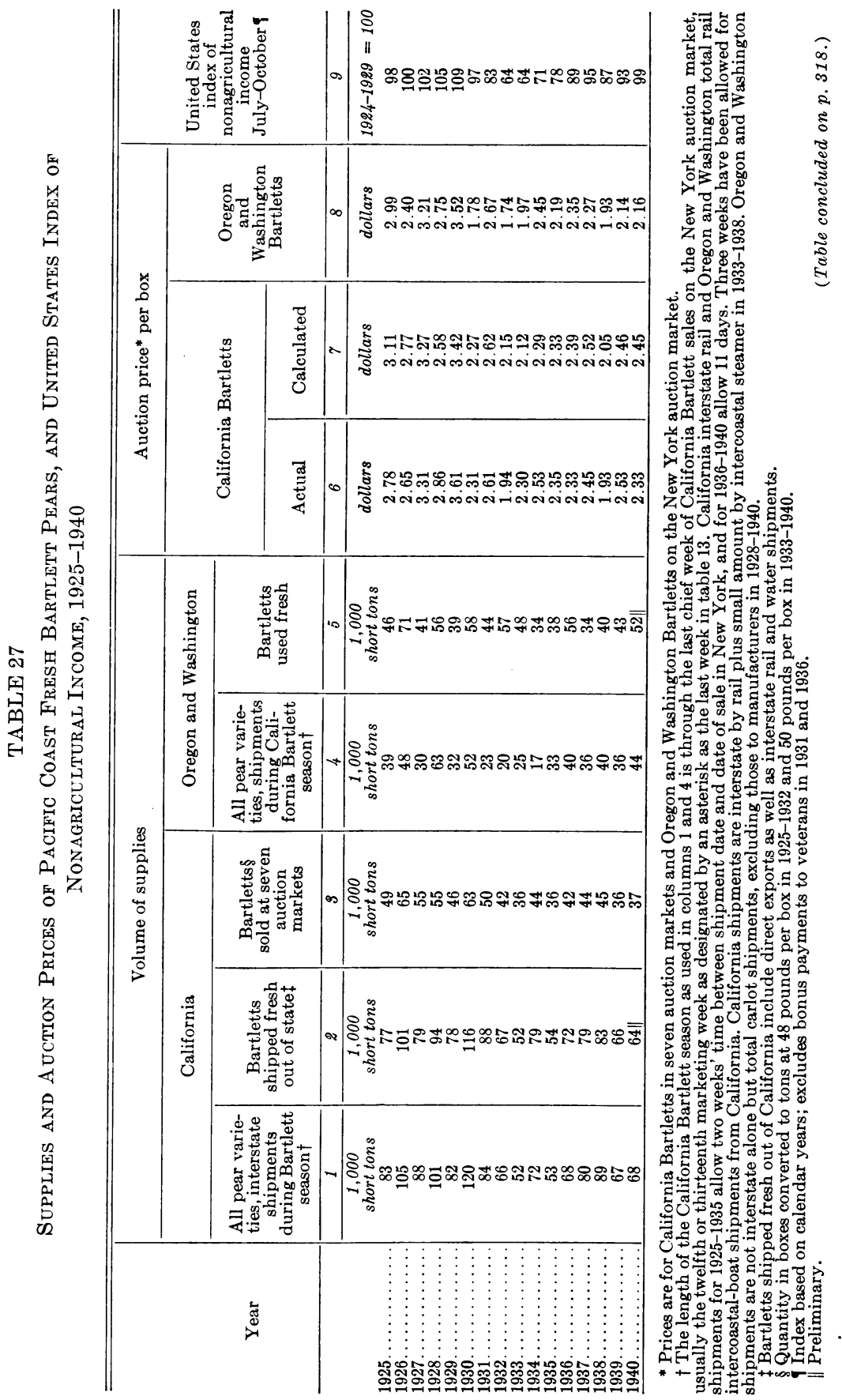




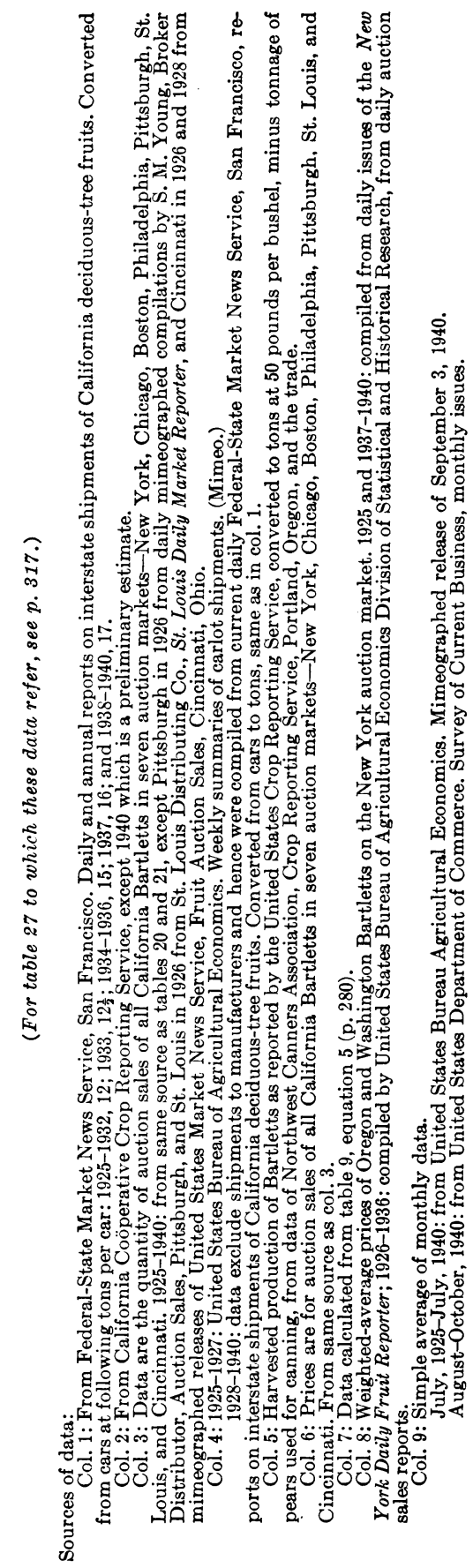


TABJE 28

Gross Returns from Caimfornia Bartilett Pears on Sevfen* MaJOR AUC'TION MARKETS, 1924-1940

\begin{tabular}{|c|c|c|}
\hline \multirow[b]{2}{*}{ Season } & \multicolumn{2}{|c|}{ Gross returns } \\
\hline & Absolute & $\begin{array}{l}\text { Percentages, } \\
1924-1929=100\end{array}$ \\
\hline & 1 & 2 \\
\hline & dollars & per cent \\
\hline $1924 .$. & $5,997,450$ & 90.5 \\
\hline $1925 \ldots \ldots \ldots \ldots \ldots \ldots \ldots \ldots$ & $5,680,256$ & 85.7 \\
\hline $1926 \ldots \ldots \ldots \ldots \ldots \ldots \ldots \ldots \ldots \ldots \ldots \ldots \ldots \ldots$ & $7,134,549$ & 107.6 \\
\hline $1927 \ldots \ldots \ldots \ldots \ldots \ldots \ldots \ldots \ldots \ldots \ldots \ldots \ldots \ldots$ & $7,544,323$ & 113.8 \\
\hline $1928 \ldots \ldots \ldots \ldots \ldots \ldots \ldots \ldots \ldots \ldots \ldots \ldots \ldots \ldots \ldots$ & $6,575,414$ & 99.2 \\
\hline $1929 \ldots \ldots \ldots \ldots \ldots \ldots \ldots \ldots \ldots \ldots \ldots \ldots \ldots \ldots$ & $6,846,353$ & 103.3 \\
\hline $1930 \ldots \ldots \ldots \ldots \ldots \ldots \ldots \ldots \ldots \ldots \ldots \ldots \ldots$ & $6,080,105$ & 91.7 \\
\hline $1931 \ldots \ldots \ldots \ldots \ldots$ & $5,408,973$ & 81.6 \\
\hline $1932 \ldots \ldots \ldots \ldots \ldots$ & $3,389,378$ & 51.1 \\
\hline $1933 \ldots \ldots \ldots \ldots \ldots$ & $3,331,736$ & 50.3 \\
\hline $1934 \ldots \ldots \ldots \ldots \ldots$ & $4,435,091$ & 66.9 \\
\hline $1935 \ldots \ldots \ldots \ldots \ldots$ & $3,350,365$ & 50.5 \\
\hline $1936 \ldots \ldots$ & $3,951,236$ & 59.6 \\
\hline $1937 \ldots \ldots \ldots$ & $4,359,251$ & 65.8 \\
\hline $1938 \ldots \ldots \ldots \ldots \ldots$ & $3,486,827$ & 52.6 \\
\hline $1939 \ldots \ldots \ldots \ldots \ldots$ & $3,655,055$ & 55.1 \\
\hline $1940 \ldots \ldots \ldots \ldots \ldots \ldots \ldots \ldots \ldots \ldots \ldots \ldots \ldots \ldots \ldots$ & $3,468,826$ & 52.3 \\
\hline
\end{tabular}

* The seven markets are New York, Chicago, Boston, Philadelphia, Pittsburgh, St. Louis, and Cincinnati.

Sources of data:

Col. 1: Summation of gross returns from the seven markets based on season's prices and total sales as given in same sources as for tables 20 and 27, col. 3. Col. 2: Calculated from data in col. 1 . 